\title{
Energy transfer in the Congo deep-sea fan: from terrestrially-derived organic matter to chemosynthetic food webs
}

\author{
Pruski A.M. ${ }^{1,{ }^{*}}$, Decker Carole ${ }^{2}$, Stetten E. ${ }^{1,3}$, Vétion G. ${ }^{1}$, Martinez P. ${ }^{4}$, Charlier K. ${ }^{1,2,3,4}$, \\ Senyarich C. ${ }^{1}$, Olu Karine ${ }^{2}$
}

${ }^{1}$ Sorbonne Universités, UPMC Univ Paris 06, CNRS, Laboratoire d'Ecogéochimie des Environnements Benthiques (LECOB), Observatoire Océanologique, F-66650, Banyuls/Mer, France

2 IFREMER Centre Bretagne, Laboratoire Environnement Profond, (REM-EEP-LEP), 29280 Plouzané, France

${ }^{3}$ Sorbonne Universités, UPMC Univ Paris 06, UMR 7193, ISTeP, F-75005, Paris, France

${ }^{4}$ Université de Bordeaux, CNRS, EPHE, Environnements et Paléoenvironnements Océaniques et

Continentaux (EPOC), UMR 5805, Allée Geoffroy St. Hilaire, 33615 Pessac Cedex, France

* Corresponding author : A.M. Pruski, email address : audrey.pruski@obs-banyuls.fr

\begin{abstract}
:
Large amounts of recent terrestrial organic matter (OM) from the African continent are delivered to the abyssal plain by turbidity currents and accumulate in the Congo deep-sea fan. In the recent lobe complex, large clusters of vesicomyid bivalves are found all along the active channel in areas of reduced sediment. These soft-sediment communities resemble those fuelled by chemoautotrophy in cold-seep settings. The aim of this study was to elucidate feeding strategies in these macrofaunal assemblages as part of a greater effort to understand the link between the inputs of terrestrially-derived $\mathrm{OM}$ and the chemosynthetic habitats. The biochemical composition of the sedimentary OM was first analysed in order to evaluate how nutritious the available particulate OM is for the benthic macrofauna. The terrestrial $\mathrm{OM}$ is already degraded when it reaches the final depositional area. However, high biopolymeric carbon contents (proteins, carbohydrates and lipids) are found in the channel of the recent lobe complex. In addition, about one to two thirds of the nitrogen can be assigned to peptide-like material. Even if this soil-derived $\mathrm{OM}$ is poorly digestible, turbiditic deposits contain such high amounts of organic carbon that there is enough biopolymeric carbon and proteacinous nitrogen to support dense benthic communities that contrast with the usual depauperate abyssal plains.
\end{abstract}

Stable carbon and nitrogen isotopes and fatty acid biomarkers were then used to shed light on the feeding strategies allowing the energy transfer from the terrestrial OM brought by the turbidity currents to the abyssal food web. In the non-reduced sediment, surface detritivorous holothurians and suspension-feeding poriferans rely on detritic OM, thereby depending directly on the turbiditic deposits. The sulphur-oxidising symbiont bearing vesicomyids closely depend on the reprocessing of OM with methane and sulphide as final products. Their carbon and nitrogen isotopic signatures vary greatly among sites and could reflect the intensity of the anaerobic oxidation of methane (AOM) in the sediments. Within the vesicomyid habitats, the heterotrophic fauna exhibits a distinctively light carbon 
isotopic signature in comparison to the background sediments, clearly indicating the utilisation of chemosynthetically-derived OM. Fatty acid biomarkers further confirm that dorvilleid polychaetes consume aggregates that perform AOM. Terrestrial OM reprocessing by microbial consortium thus ensures its transfer to the benthic food web in the Congo deep-sea fan.

Keywords: Congo deep-sea fan, Food webs, Vesicomyid bivalves, Chemoautotrophy, Isotopic signatures, Fatty acid biomarkers 


\section{Introduction}

With the exception of chemosynthetic productivity hotspots such as hydrothermal vents and cold seeps, the rain of particulate organic matter settling onto the seafloor is the principal source of energy for the benthic fauna in most abyssal ecosystems (Danovaro, Snelgrove, and Tyler 2014; Smith et al. 2008). Marine inputs of organic matter (OM) to the deep seafloor are remarkably low in comparison to the biological production in the euphotic zone (Hedges and Keil 1995; Lee, Wakeham, and Arnosti 2004) and are highly degraded, but seasonal pulses of higher quality OM may influence benthic ecosystems. This has been shown along the Congo-Angola margin (Picaut 1983; Soltwedel 1997; Voituriez and Herbland 1982), where a coastal upwelling enhances organic inputs to the deepsea (Rabouille et al., 2009). Additionally, about $5 \%$ of the terrestrial OM delivered by rivers to the ocean bypasses the continental shelf and feeds the deep ocean (Meade, 1996). Although regional by nature and clearly linked to the presence of river mouths and associated submarine canyons, this OM source is able to reach great depths and large distances from the coast. As such, the distal lobe complex of the Congo deep-sea fan is ideal to investigate how the abyssal fauna responds to terrestrial OM inputs. The distal lobe complex is linked to the Congo River by an active submarine canyon enabling the rapid transfer of massive amounts of continental material to the deep-sea (Babonneau et al., 2002; Savoye et al., 2009). Terrestrial OM fuels the seafloor at a regional scale in the Congo deep-sea fan (Baudin et al., 2010; Sibuet and Vangriesheim, 2009; Stetten et al., 2015) and represents the main resource for benthic organisms and microorganisms. Macro- and meiofaunal abundance as well as biomass are particularly high in the Gulf of Guinea (Galéron et al. 2009; Van Gaever et al. 2009), with no clear trend for decreasing densities as water depth increases, except inside the channel itself (Van Gaever et al. 2009). However, macrofaunal and meiofaunal densities were remarkably lower on the levee $15 \mathrm{~km}$ South of the Congo deep-sea channel compared to 150 $\mathrm{km}$ further south, raising the question of the nutritional quality of the material delivered by turbidity currents along the Congo deep-sea channel (Galéron et al., 2009). The organic-rich turbidites are composed of soil-derived OM, detritus of vascular plants and degraded marine OM (Stetten, 2015). 
Terrestrial $\mathrm{OM}$ is known to be more refractory than marine $\mathrm{OM}$, and its origin and age largely determine its bioavailability for benthic organisms (Tenore et al., 1984). So far, studies dedicated to the characterisation of the $\mathrm{OM}$ in the Congo deep-sea fan have mainly focused on its distribution, origins and state of maturation (Baudin et al., 2010; Baudin et al., 2017, this volume; Stetten et al., 2015; Treignier et al., 2006). Conversely, our understanding of the ecological impact of turbidity currents and their deposits is more limited and mostly restricted to the channel-levee system between 3,000 and 4,000 m of depth (Galéron et al., 2009; Khripounoff et al., 2015; Van Gaever et al., 2009). These previous studies mainly focus on community structure and function, but also discuss the potential influence of marine versus terrestrial OM sources depending on the distance from the active channel.

Preliminary characterisation of the distal lobe complex, which corresponds to the present-day turbidity current depositional areas in the abyssal plain, revealed high mineralisation rates of organic carbon, whose contents are exceptionally high at these depths (3\%, Rabouille et al., 2009). Macrofaunal communities in the lobe complex area have been recently studied (Olu et al., submitted, this volume), but the link between the turbidity currents and the transfer of energy to the benthic foodweb has not been addressed so far. Moreover, the observation of faunal aggregations and microbial mats similar to those colonising cold-seeps (Rabouille et al., this volume; Sen et al., submitted, this volume) raised the question of the origin of the reduced compounds (hydrogen sulphide) required for their development and the link with the turbidites. We particularly focused the sampling in habitats created by vesicomyid bivalves, resembling those colonising cold-seeps on pockmarks of the same region (Olu et al., 2009; Olu-Le Roy et al., 2007), with high densities and shared species (Decker et al., in press, this volume; Rabouille et al., this volume; Teixeira et al., 2013). In the present article, we first examine the quality of the particulate $\mathrm{OM}$ available for the nutrition of benthic invertebrates in the distal lobe complex. We then present stable elemental (carbon and nitrogen) isotopic and fatty acid compositions of the representative species inhabiting the vesicomyid bivalve habitats and the surrounding sediments, in order to shed light on the feeding 
strategies allowing the energy transfer from the terrestrial OM brought by the turbidity currents to the abyssal biosphere in this unique ecosystem. Finally, the biogeochemical and ecological functions provided by these communities in the nutrient-rich turbiditic ecosystem are discussed.

\section{Material and Methods}

\subsection{Description of the study sites}

The Congo deep-sea fan, located on the Congo-Angola margin in the southern Atlantic Ocean, is one of the largest deep-sea fans in the world (Savoye et al., 2009) (Fig. 1A). The lobe complex area is located on the Congo-Angola margin, $800 \mathrm{~km}$ away from the Congo River mouth, and is between $4700 \mathrm{~m}$ and $5100 \mathrm{~m}$ deep (Fig. 1A). This complex covers $2500 \mathrm{~km}^{2}$ and constitutes the terminal area of the active channel (see details in Dennielou et al., 2017, this volume).

Two field campaigns (WACS leg 2 and Congolobe) were held in 2011 on the distal lobe complex area in order to conduct sedimentological, biogeochemical and biological studies in this almost unique system (Olu, 2011; Rabouille, 2011). A complete description of the studied area and our sampling strategy is given in Rabouille et al. (this volume). Briefly, three sites are located along the active channel: Site A at the entrance of the distal lobe complex (Fig. 2), Site F 40km downstream (Fig. 3), and Site $\mathrm{C}$ in the most distal reach of the active channel (Fig. 3). Site B is located $10 \mathrm{~km}$ north east of the active channel (Fig. 1B). Site $E$ is located $45 \mathrm{~km}$ off the feeding channel of the recent lobe complex, in an older lobe complex now disconnected from the active system.

ROV video surveys revealed habitats made of dense vesicomyid populations associated to bacterial mats and reduced sediments all along the active channel at Sites A, F and C (Figs. 5A-E, see detailed mapping in Sen et al., submitted, this volume). Macrofauna densities within the vesicomyid beds were not higher than in the adjacent sediments, but dominated by sulphide-tolerant polychaete families (Ampharetidae, Hesionidae), whereas Dorvilleidae dominate in the most reduced sediments (Olu et al., submitted, this volume). Communities in these particular habitats resemble those of the 
giant REGAB pockmark (Fig. 5F), but are sustained by different biogeochemical processes (Olu et al., 2009; Olu-Le Roy et al., 2007; Sen et al., submitted, this volume).

\subsection{Sampling procedure}

Sediments and selected macrofauna were sampled to investigate the relationship between the turbiditic transfer of terrestrial $\mathrm{OM}$ and the functioning of the benthic communities. During the Congolobe field campaign, short sediment cores were sampled using a multicorer MUC 8/100 (Oktopus $\mathrm{GmbH}$ ) and were rapidly sliced into 11 layers $(0-0.5 \mathrm{~cm} ; 0.5-1 \mathrm{~cm} ; 1-2 \mathrm{~cm} ; 2-3 \mathrm{~cm} ; 3-5 \mathrm{~cm}$; 5-7 cm; 7-10 cm; $10-13 \mathrm{~cm} ; 13-16 ; 16-19 \mathrm{~cm} ; 19-22 \mathrm{~cm})$. The layers were carefully homogenised, conditioned in Falcon tubes, and stored at $-80^{\circ} \mathrm{C}$. The biochemical analyses were performed on five cores collected outside the vesicomyid habitats in the active channel (Sites A, F), the depositional area of Site C and the distant Sites B and E (see list of cores in Table 1). Bulk geochemical properties for these cores are given in Stetten et al. (2015). Since the sediment sampled in the whole area were pretty homogenous in their bulk geochemical composition (Baudin et al., 2017, this volume; Stetten et al., 2015), the data shown here on the different sites can be considered representative of the OM originally deposited in the whole lobe complex. In addition, we analysed several wetland sediment samples collected along a transect across the Congo River at the Malebo pool (Talbot et al., 2014; Fig. 1A). They consist in permanently submerged sediments (PS), floodplain sediments (FP) and bank sediments (BS), and will be considered in this study as potential terrestrial sources.

Opportunistic collections of megafauna and macrofauna were made during the WACS and Congolobe field campaigns using a suction sampler and nets manipulated by the ROV Victor 6000 , as well as from blade cores used to study macrofauna structure (Olu et al., submitted, this volume). Only the largest taxa $(>1 \mathrm{~cm})$ were analysed for trophic studies (see Table 2). Although limited, the sampling was representative of the benthic communities present in the distal lobe complex of the Congo deepsea fan, with both classical abyssal communities in background sediments and fauna from chemosynthesis-based habitats, as well as different feeding types. Representative views of habitats 
and macrofauna are given in Figure 2. The megafauna included mobile translucent holothurians that may belong to different families of the Elasipodida order (M. Sibuet, Pers. Com.) and a swimming purple holothurian species that is likely the Synallactidae Paleopatides gigantea. The translucent holothurians were found inside patches of clams (living at Site A and mostly dead at Site B) and on the surrounding sediments. Poriferans were present at Site E, in the older lobe complex. Three different species were collected: a tulip-shaped glass-sponge of the Hyalonema genus, a large yurtshaped sponge and a white elongated sponge with thorns (referred to in the present text as the thorny sponge). Commensal amphipods were recovered from the yurt-shaped sponge. Two vesicomyid species were sampled, namely Christineconcha regab (Krylova and Cosel, 2011) and Abyssogena southwardae (Krylova et al., 2010). The Munidopsis crassa galatheids (E. Mac Phearson, Pers. Com.) have been sampled either in vesicomyid beds (at Site F) or in background sediments (at Site E). Other taxa sampled in vesicomyid clusters include actinians living on vesicomyid shells, Ampharetidae and Dorvilleidae polychaetes. Ampharetidae have been sampled in a vesicomyid patch (Site $\mathrm{C}$ ) and Dorvilleidae in a mixed habitat of vesicomyids and microbial mats at Site $\mathrm{F}$.

\subsection{Biochemical analyses of sedimentary organic matter}

Total carbohydrates were assayed in triplicates using the protocol described by Dubois et al. (1956). In this assay, simple sugars, oligosaccharides and polysaccharides present in the sediments are treated with phenol and concentrated sulphuric acid and give an orange-yellow colour which is measured at $490 \mathrm{~nm}$ by spectrophotometry. Quantification is done using a glucose standard solution. Total lipids were analysed in triplicate following the protocol described by Barnes and Blackstock (1973). Briefly, lipids are extracted by liquid-liquid partition with chloroform/methanol (2v:1v), hydrolysed with hot sulphuric acid and react with a phosphoric acid-vanillin reagent to give a reddish colour whose absorbance is measured at $520 \mathrm{~nm}$ by spectrophotometry. Quantification is done using a cholesterol standard solution. Analytic precision for carbohydrates and lipids was less than $10 \%$. 
To determine the monomeric amino acid composition, total hydrolysable amino acids (THAAs) were extracted from freeze-dried sediments $\left(15 \mathrm{mg}\right.$ ) by acid hydrolysis (hot $6 \mathrm{~N} \mathrm{HCl}, 24 \mathrm{~h}, 110^{\circ} \mathrm{C}$ ) and the hydrolysates were treated according to a procedure based in part on the EZ:faast Amino Acid Analysis kit from Phenomenex (Badawy, 2012), but derivatization was carried out directly in aqueous samples (Dettmer et al., 2012). Briefly, an aliquot of the hydrolysate was neutralised with $\mathrm{NaOH} 6 \mathrm{~N}$ and buffered by $\mathrm{K}_{2} \mathrm{CO}_{3} / \mathrm{KHCO}_{3}$. An internal standard (norvaline) was added and samples were alkylated using propyl-chloroformate in the presence of $n$-propanol and pyridine. Carbamates were recovered by liquid-liquid partition using isooctane, purified and analysed on a gas chromatograph (CLARUS 580) fitted with a ionisation flame detector (Perkin Elmer). Separation was achieved on a 30m long ZB HT 35 inferno column (Phenomenex). Amino acids were identified and quantified using standard solutions of amino acids of known concentrations and calibration curves established for each amino acid. Repeatability of the analysis was determined by comparing relative standard deviations of 16 amino acids in five extractions performed on one sediment sample. Relative standard deviations for the amino acids were in the 3-8\% range, whereas the coefficient of variation for total amino acid concentrations was $7 \%$.

The obtained mole percentages were used to calculate the degradation index (DI), which synthesises subtle changes in the amino acid composition linked with diagenesis into a univariate variable indicative of OM degradation stage (Dauwe et al., 1999a). As arginine does not produce stable carbamates, this amino acid was omitted from the DI calculation. In Dauwe's initial dataset, the DI varied from -2.2 for extensively degraded sediments to +1.5 for fresh algae, but more extreme values have been reported (Unger et al., 2005).

The reactivity index $[R I=($ tyrosine + phenylalanine $) /(\beta$-alanine $+\gamma$-butyric acid $)]$ proposed by Jennerjahn and Ittekkot (1997) is another indicator of OM degradation. It takes into account two opposite trends: the reactive aromatic amino acids, tyrosine and phenylalanine, are rapidly degraded in decaying $\mathrm{OM}$, whereas the non-proteic amino acids, $\beta$-alanine and $y$-butyric acid, consistently increase in degraded sediments (Alkhatib et al., 2012; Unger et al., 2005). Deep-sea sediments 
typically exhibit DI values below -1 (Dauwe et al., 1999a) and RI values below 0.5 (Jennerjahn and Ittekkot, 1997).

Biopolymeric carbon (BPC) was defined as the sum of the carbon equivalents of total carbohydrates, proteins and lipids. Conversion factors of 0.4 and 0.75 were used to determine carbon equivalents of carbohydrates and lipids (Danovaro et al., 2001), whereas THAAs were used instead of proteins in the $\mathrm{BPC}$ calculation. The fraction of organic content $(\mathrm{OC})$ contained in the amino acids $\left(\% \mathrm{~T}_{\mathrm{AA}} \mathrm{C}\right)$ and the protein-nitrogen $\left(\% \mathrm{~T}_{A A} \mathrm{~N}\right)$ were inferred from individual compound concentrations, the number of carbon or nitrogen atoms in each compound and elemental composition in OC or nitrogen. Total nitrogen content (TN) was determined using a Thermo Fischer Flash 2000 after removal of carbonates with $\mathrm{HCl}(1 \mathrm{~N})$ (Stetten et al., 2015). We checked that acidification did not affect TN values by comparing untreated and acidified TN values for a subset of samples; a good linear correlation with a $y$-intercept close to zero was obtained $\left(y=1.1321 x+0.0049, R^{2}=0.8999, n=15\right)$. Considering that carbon in proteins comes from individual amino acid monomers, $\mathrm{T}_{\mathrm{AA}} \mathrm{C}$ will be considered in the text as a good estimate of the proteic carbon.

Finally, the digestibility of the organic matter was assayed on the surface layer following the biomimetic approach proposed by Mayer et al. (1995). In this protocol, an enzymatic treatment enables to release the amino acids which are bioavailable (see Appendix B for detailed protocol).

\subsection{Carbon and nitrogen isotopic analysis of the mega- and macrofauna}

All specimens were dissected in a cold room onboard the research vessel. The mantle and gill tissues of vesicomyid bivalves were dissected on board and tissues were stored at $-80^{\circ} \mathrm{C}$. We also used vesicomyids fixed either in ethanol 96 , or in formalin for $48 \mathrm{~h}$ and then stored in ethanol 80 . These specimens were subsequently dissected in the laboratory. No effect of fixation mode was observed between individuals of the same species and from the same site for carbon and nitrogen isotopic signatures (Kruskal Wallis and Wilcoxon-Mann-Whitney tests, $p>0.1$, see Table A1 in the Appendix

A). Other taxa were fixed in ethanol 96, except one galatheid (sample ID \#14) and one holothurian 
(sample ID \#26). When possible, muscular parts were dissected for isotopic analyses. Tegument was used for holothurians, as it is difficult to remove the circular and longitudinal muscles from it. For smaller taxa (polychaetes) digestive tracts were removed.

Freeze-dried samples of invertebrate tissues were ground to a homogeneous fine powder and less than $1 \mathrm{mg}(0.3-0.5 \mathrm{mg})$ was folded into tin cups (9-mm high and 5-mm in diameter). Stable-isotope ratio measurements were performed on a Thermo Fischer Flash 2000 Elemental Analyzer in line with a VG Isoprime Mass Spectrometer. The analytical precision was $0.2 \%$ for both $\delta^{13} \mathrm{C}$ and $\delta^{15} \mathrm{~N}$, estimated from several calibrated laboratory standards analysed along with the samples. Stable isotopic ratios are reported as: $\delta^{A} X=\left[\left(R_{\text {sample }} / R_{\text {std }}\right)-1\right] * 1,000$

where $A$ is the atomic mass of the heavy stable isotope of element $X$, and $R_{\text {sample }}$ and $R_{\text {std }}$ are the ratios of heavy to light isotope of sample and standard, respectively. The standards are atmospheric nitrogen for nitrogen isotopes and Vienna Pee Dee Belemnita (PDB) for carbon isotopes.

The percentage of methane-derived carbon in the diet of the associate fauna was estimated using a two-source isotope mixing model (Fry and Sherr, 1984) using the equation employed by Levin and Michener (2002): $\quad \mathrm{Fm}=\frac{\delta^{13} \mathrm{Ci}-\delta^{13} \mathrm{C}_{\text {source2 }}}{\delta^{13} \mathrm{C}_{\text {methane }}-\delta^{13} \mathrm{C}_{\text {source } 2}}$ where $\mathrm{Fm}$ is the percentage of methane-derived carbon in the diet of the taxon, and $\delta^{13} \mathrm{Ci}$ the carbon isotopic signature of the taxon. As detailed in Decker and Olu (2012), no trophic shift was included for $\delta^{13} \mathrm{C}$ and we considered two different 'source 2 ' end-members to estimate upper and lower percentages of methane-derived carbon in animals. The lower estimate was obtained using the $\delta^{13} \mathrm{C}$ signature of sulphide-oxidising bacteria $\left({ }^{13} \mathrm{C}_{\mathrm{SOB}}\right)\left(\mathrm{F}_{\mathrm{m} / \mathrm{sOB}}\right)$ and the upper estimate using the $\delta^{13} \mathrm{C}$ signature of particulate organic carbon $\left(\delta{ }^{13} C_{\mathrm{POC}}\right)\left(\mathrm{F}_{\mathrm{m} / \mathrm{POC}}\right)$. We used a $\delta^{13} \mathrm{C}_{\mathrm{POC}}$ value of $-26.5 \%$ o for sedimentary $\mathrm{OM}$ in the background sediments from the recent lobe complex (Table 1 ) and a $\delta^{13} C_{\text {methane }}$ value of $-70 \%$ (Pastor et al., 2017, this volume). Since no estimation for $\delta^{13} C_{\text {soв }}$ from bacterial mats was available, we used the averaged $\delta^{13} \mathrm{C}$ signature of the vesicomyid gills $(-38.16 \pm$ 0.84 , Table A1) as they housed sulphide-oxidising bacteria. 


\subsection{Fatty acid biomarker analysis of animal tissues}

For fatty acid analysis, animals were conditioned rapidly after their collection. Small animals were frozen directly after removal of the digestive tract and larger animals were dissected on ice (Table 2). The gills and foot of vesicomyids were preserved, whereas for holothurians and sponges the tegument was isolated. Samples were stored at $-80^{\circ} \mathrm{C}$, freeze-dried in the laboratory, and ground to a fine powder in a liquid nitrogen-cooled excelsior mill (IKA A11 Basic, IKA ${ }^{\circledast}$, Service lab France). Total fatty acids (free and bound) were extracted on an aliquot of freeze-dried tissues (15 to $500 \mathrm{mg}$ depending on the species) and methylated using a direct acid transesterification procedure detailed in Bourgeois et al. (2011). Fatty acid methyl ester (FAME) extracts were analysed on a gas chromatograph (Varian 3900) fitted with a Saturn 2100T ion trap detector (Varian) and quantified as described in Bourgeois et al. (2011). Identification of individual fatty acids was based on comparison of retention times and mass spectra with commercial standards and was confirmed with NIST library. Identification was performed as far as possible without further derivatization, and allowed major compounds and most of the minor ones to be identified. We did not focus on identifying new compounds as our final goal was to study feeding strategies, which could be achieved using known biomarkers. Fatty acids used as trophic biomarkers, in this study, are listed in Table 3.

Repeatability of the analysis, determined by comparing relative standard deviations of 41 fatty acids in six different preparations of our standard solution, ranged from $1.0-5.4 \%$ with a mean value of 2.4\% (Pruski et al., 2015). Results are expressed in $\mu \mathrm{g} \cdot \mathrm{g}^{-1} \mathrm{DW}$ tissues or $\%$.

\subsection{Statistical treatments}

Non-parametric rank tests were performed on the carbon and nitrogen isotope signatures of the two vesicomyid species $(\alpha=0.05)$. We tested for isotopic differences between species (Wilcoxon-MannWhitney $U$ test), tissues (Wilcoxon-Mann-Whitney $U$ test) and sampling sites (Kruskal-Wallis test). Fatty acid profiles were compared using a non-parametric statistical software package, PRIMER Version 6 (Clarke and Gorley, 2006). The initial dataset included 24 samples and percentages for 70 
fatty acids. Fatty acids present in trace amounts $(<0.5 \%)$ or occurring in less than half of the samples were removed. Groups of fatty acids were made for certain compounds that were rare, but still biologically relevant (see Table C1 in Appendix C for a full description of the dataset). The percentages of the 21 remaining variables were normalised to $100 \%$ prior to analysis. First, a resemblance matrix was generated based on the Bray and Curtis similarity measure. A 2D non-metric multi-dimensional scaling (NMDS) plot was then produced to compare fatty acid profiles of the macrofauna. A hierarchical cluster analysis (CLUSTER function) was performed on the same similarity matrix with the group average mode to determine levels of similarity between groups of samples. The SIMPER function (Similarity percentages) was used to determine which fatty acids were most responsible for any similarity or dissimilarity between groups (i.e. among taxa, and between vesicomyid species and tissues). Analyses were performed on non-transformed data.

\section{Results}

\subsection{Sedimentary organic matter characteristics in the lobe complex}

Geochemical and molecular parameters reported here and in Stetten et al. (2015) are compiled in Table 1. The isotopic signature of background sediments collected in the recent lobe complex exhibited little variation, averaging $26.5 \% \circ \pm 0.4 \%$ and $5.3 \% \circ \pm 0.4 \%$ for $\delta^{13} \mathrm{C}_{\text {org }}$ and $\delta^{15} \mathrm{~N}$, respectively (arithmetic means calculated for Sites A, F, C and B according to Stetten et al., 2015, n= 67). Sediments in the abandoned lobe (Site E) were characterised by less depleted $\delta^{13} \mathrm{C}$ and $\delta^{15} \mathrm{~N}$ ratios $(-24.2 \% \circ \pm 1.4 \%$ ond $7.2 \% \circ \pm 0.8 \%$ ) , consistent with their hemipelagic origin.

High organic carbon $(\mathrm{OC})$ contents were found in sediments from the recent lobe with average values comprised between $3.2 \% \pm 0.3$ and $3.9 \% \pm 0.4$ for Sites $A$ and $C$, respectively (Table 1 ). While no decrease in the $O C$ content was observed $10 \mathrm{~km}$ away from the active channel (Site B), the abandoned lobe (Site E) exhibited remarkably lower values $(1.9 \% \pm 0.7)$. Total hydrolysable amino acid (THAA), carbohydrate, lipid and biopolymeric carbon (BPC) concentrations followed the same trends (Table 1). BPC in the distal lobe complex was on average around 9.1 to $9.7 \mathrm{mgC} . \mathrm{g}^{-1} \mathrm{DW}$, a little 
less at Site B with a value of $8.3 \mathrm{mgC} . \mathrm{g}^{-1} \mathrm{DW}$ and two-fold lower at Site $\mathrm{E}$ with $4.9 \mathrm{mgC} . \mathrm{g}^{-1} \mathrm{DW}$. The BPC was generally dominated by proteins, which accounted for approximately $50 \%$ of the total mass, and to a lesser extent by carbohydrates ( $35-40 \%$ of the BPC; Fig. 6). Sediments from Site E were enriched in carbohydrates, which accounted for up to $45 \%$ of the BPC (Fig. 6). Lipids represented a minor fraction of the BPC $(\leq 11 \%)$.

Nitrogen contained in the THAA fraction $\left(\% \mathrm{~T}_{\mathrm{AA}} \mathrm{N}\right)$ accounted for one-third to two thirds of the total nitrogen in the lobe sediments, with lower values at Site E (Table 1). The monomeric hydrolysable amino acid composition of the surface sediments was dominated by glycine (>16\%), aspartic acid + asparagine (10.5-14.3\%), alanine (9.3-9.6\%), glutamic acid + glutamine (7.3-9.9\%), threonine (7.28.0\%), serine (7.4-8.0\%), and valine (6.4-7.8\%), whereas leucine, proline, lysine, isoleucine, phenylalanine and histidine were less abundant (1 to 6\%) (Fig. 7B). Globally, the momomeric hydrolysable amino acid composition of the lobe sediments was similar to the composition of sediments collected on the African continent (Fig. 7A), in good agreement with their presumed terrestrial origin (Stetten et al., 2015). Moreover, hydroxyproline, a biochemical tracer of plantderived nitrogen (Philben and Benner, 2013), was present everywhere in the recent lobes at the exception of Site E, which is dominated by hemipelagic inputs (Stetten et al., 2015). Sediments from the lobes were enriched in glycine and bacterial amino acids, whereas aspartic acid and glutamic acid contributions were lower. DI values in sediments were in general negative at the exception of Site C (Table 1). In the recent lobes, the average RI values for the sediment cores varied from $0.93 \pm 0.24$ to $1.38 \pm 0.31$ for Sites F and C, respectively (Table 1 ). Site E was characterised by the lowest DI and RI values, indicative of a more advanced stage of degradation (Dauwe et al., 1999a; Jennerjahn and Ittekkot, 1997). The enzymatically hydrolysable amino acids (EHAAs) only accounted for about 10 to $12 \%$ of the THAAs in the recent lobe and for $14.5 \%$ in the abandoned one (see Fig. B1 in Appendix B).

\subsection{Isotopic signatures of the benthic fauna}


Mobile and sessile specimens collected outside the vesicomyid habitats displayed the most enriched

${ }^{13} \mathrm{C}$ and ${ }^{15} \mathrm{~N}$ signatures (Fig. 8A). The three sponges exhibited narrow ranges of $\delta^{13} \mathrm{C}(-19.5 \pm 0.5 \%$ ) and $\delta^{15} \mathrm{~N}(16.3 \pm 1.2 \%$ ) values. Holothurians had uniform isotopic composition (except for the Synallactidae) regardless of the collection sites and were slightly enriched in ${ }^{13} \mathrm{C}$ and ${ }^{15} \mathrm{~N}(-21.3 \%$ and $8.4 \%$ ) compared to the surrounding sediments. The Synallactidae (purple holothurian) deviated from this typical signature, with higher $\delta^{13} \mathrm{C}(-16.9 \%)$ and $\delta^{15} \mathrm{~N}(14.2 \%)$ values, and appeared to derive its carbon and nitrogen from the same source as the sponges and a solitary actinarian (see Table A1 in Appendix A).

In the reduced sediments where the symbiont-bearing vesicomyids live, the fauna derived its food from ${ }^{13} \mathrm{C}$-depleted sources. The two vesicomyid species exhibited carbon isotopic signatures consistent with reliance on thiotrophic symbionts for nutrition (average $\delta^{13} \mathrm{C}=-38.9 \pm 2.8 \%$ o and $-38.2 \pm 0.8 \%$ o for mantle and gills, respectively; Fig. 8 B). Overall, C. regab displayed a wider range of $\delta^{13} \mathrm{C}$ values than $A$. southwardae. The comparison of the mantle $\delta^{13} \mathrm{C}$ values along the active channel (Sites $A, F$ and C) shows that this variability is linked to the sites (Kruskal-Wallis test, $p=0.001$ ), with specimens from Site $\mathrm{C}$ exhibiting the most ${ }^{13} \mathrm{C}$-depleted values. The nitrogen isotopic signature of $A$. southwardae was more depleted in ${ }^{15} \mathrm{~N}$ than C. regab and this trend was statistically significant for both mantle and gills (Wilcoxon-Mann-Whitney test, $p=0.001$ ). In addition, gills were always more depleted in ${ }^{15} \mathrm{~N}$ than mantle tissues.

The associated fauna analysed from the vesicomyid habitats was composed of annelids (Ampharetidae and Dorvilleidae polychaetes), epicommensal actinarians and crustaceans (Galatheidae). As for the symbiont-bearing clams, they exhibited a $\delta^{13} \mathrm{C}$ signature that was consistently depleted in comparison to bulk sedimentary OM. Dorvilleidae exhibited the lowest $\delta^{13} \mathrm{C}$ values $(-44.8 \pm 2.9 \%$ ) , followed by Ampharetidae $(-38.9 \pm 1.3 \%$ ), Galatheidae $(-33.1 \%$ ) and the epicommensal actinarians (-31.5\%). Upper and lower estimates of methane-derived carbon in polychaetes were 21 and $42 \%$ for Dorvilleidae and 2.5 and $29 \%$ for Ampharetidae. The fauna associated to the Congo vesicomyid habitat was also characterised by extremely low $\delta^{15} \mathrm{~N}$ signatures 
$\left(-5.5\right.$ to $3.4 \%$ ) compared to sedimentary organic matter delivered by turbidity currents. While $\delta^{15} \mathrm{~N}$ values were uniform for the Dorvilleidae $(-2.9 \pm 0.2 \%$ ), they were more variable for the Ampharetidae ( $1.3 \pm 1.8 \%$ ) , Galatheidae (0.1 to $3.4 \%$ ) and actinarians ( -3.5 to $15.8 \%$ ).

\subsection{Fatty acid biomarkers of trophic transfer}

Total fatty acid contents in the benthic macrofauna were variable, with the lowest values found in the holothurians and the highest in the amphipods (Table 4). The MDS plot shows that fatty acid profiles displayed distinct features among taxa, but also within a group of organisms (Fig. 9).

The two holothurians were collected on the same site, but they were remarkably dissimilar with regard to their fatty acid content and molecular composition (Fig. 9, 51\% similarity). Holothurian \#5 was enriched in fatty acids by a threefold factor $\left(641 \mu \mathrm{g} \cdot \mathrm{g}^{-1} \mathrm{DW}\right)$ in comparison to the other specimen (222 $\mu \mathrm{g} \cdot \mathrm{g}^{-1} \mathrm{DW}$ ) and its tissues were dominated by the presence of polyunsaturated fatty acids

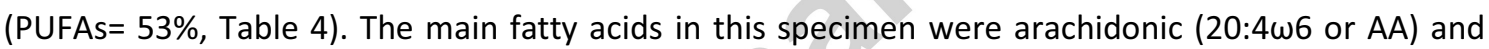
docosahexaenoic (22:6w3 or DHA) acids, which accounted each for about $23 \%$. Palmitic acid (16:0) only contributed to $11 \%$ and monounsaturated fatty acids (MUFAs) for $15 \%$. Specific bacterial fatty acids (BAFAs) included odd-number, methylbranched, and hydroxylated fatty acids and accounted for a further $9 \%$. The other holothurian (\#4) was characterised by higher contributions of mid-chain saturated fatty acids (MC-SAFAs, $22 \%$ of $16: 0$ and $16 \%$ of $18: 0$ ) and MUFAs ( $35 \%$ ) with the marked

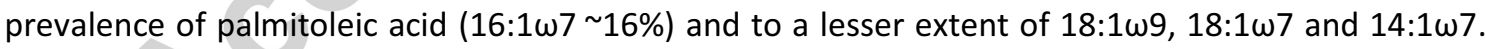
In contrast, PUFA content was relatively low (14\%, Table 4).

The three poriferans analysed belonged to distinct species and the yurt-like sponge exhibited remarkably lower fatty acid content $\left(0.98 \mathrm{mg} \cdot \mathrm{g}^{-1} \mathrm{DW}\right)$ than the other two species $(4.22$ and $5.47 \mathrm{mg} . \mathrm{g}$

${ }^{1}$ DW) (Table 4). Still, their fatty acid composition was relatively similar (81\% of similarity, Fig. 9). A high PUFA contribution characterised the three poriferans (49 to $68 \%$, Table 4 ) with the prevalence

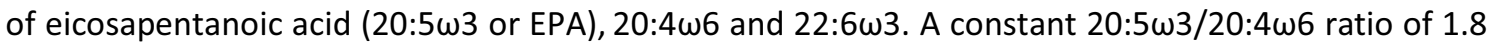
was observed. MUFAs were also an important source of fatty acids (21 to 30\%) with strong 
contributions of $18: 1$ isomers. Yet, differences in the relative proportion of the $\omega 7$ and $\omega 9$ were observed; the $\omega 7$ isomer was prevalent in the yurt-like sponge whereas the $\omega 9$ isomer dominated in Hyalonema sp. and the thorny sponge. Long-chain MUFAs (LC-MUFAs $=\mathrm{C}_{20-24}$ ) were also abundant in the yurt-shaped and thorny sponges (14 and 12\% respectively) with the prevalence of an unidentified $\mathrm{C}_{24}$ moiety. Common short- and mid-chain saturated fatty acids (SAFAs) represented a minor component of the fatty acid pool in the poriferans (8 to 15\%), in contrast with the typical composition of most invertebrates. BAFAs were more abundant in the yurt-shaped sponge (7\%) than in the thorny sponge (3\%) and Hyalonema sp. (2\%).

The fatty acid profiles of amphipods were globally similar to the composition of their host, the yurtshaped sponge, with a high contribution of PUFAs (55\%). SIMPER analysis of dissimilarity shows that lower $20: 5 \omega 3$ and $20: 4 \omega 6$, and higher $22: 6 \omega 3$ and $18: 1 \omega 9$ were the main contributors of dissimilarity between the amphipods and their host (Table C1 in Appendix C). The amphipods were also characterised by the presence of $20: 3 \omega 3(5 \%)$.

Dorvilleid annelids exhibited high fatty acid contents $\left(65.6 \pm 17.5 \mathrm{mg}^{-1} \mathrm{~g}^{-1} \mathrm{DW}\right)$. The contribution of PUFAs was high in the worms ( $48 \%$, Table 4$)$ and dominated by $20: 5 \omega 3$ and an isomer of

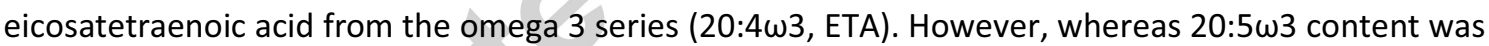
quite constant among samples $\left(12.6 \pm 1.0 \mathrm{mg} \cdot \mathrm{g}^{-1} \mathrm{DW}\right), 20: 4 \omega 3$ was more variable $\left(0.9\right.$ to $14.2 \mathrm{mg} \cdot \mathrm{g}^{-1}$ DW). A total of 19 PUFAs were identified in the Dorvilleidae, among which the omega 3 series dominated, followed by omega 4 and omega 6 (Table 4). Mid chain-MUFAs (MC-MUFAs) were also abundant (43\%) with the prevalence of $18: 1 \omega 7$ (26\%). LC-MUFAs were also present ( $6 \%)$, as well as unusual MUFAs of the omega 5 series. Odd and branched bacterial fatty acids were only present as trace amounts, whereas hydroxylated and cyclopropane fatty acids were absent. SAFA content was low $(<9 \%)$.

Fatty acid concentrations were elevated in vesicomyids ( 25.5 to $40.5 \mathrm{mg} \cdot \mathrm{g}^{-1} \mathrm{DW}$ ). Fatty acid content in $A$. southwardae exhibited little variability and were higher in the gills than in the feet $(38.3 \pm 2.7$ and $25.3 \pm 1.6 \mathrm{mg} \cdot \mathrm{g}^{-1} \mathrm{DW}$, respectively, Table 4). In contrast, more variability was observed with $C$. 
regab and there was no clear trend between tissues $\left(25.2 \pm 7.0\right.$ and $28.5 \pm 2.6 \mathrm{mg} \cdot \mathrm{g}^{-1} \mathrm{DW}$, respectively, Table 4). Gills and feet displayed distinct fatty acid profiles, but their composition was similar for the two species ( $<10 \%$ dissimilarity). The gills were characterised by $16: 1 \omega 7$, which accounted for about one half of the total fatty acids ( $51 \%$ in $A$. southwardae and $46 \%$ in C. regab). This biomarker of thiotrophic bacteria (Conway and McDowell Capuzzo, 1991) was also found in the feet, but in lower proportions (15\% in A. southwardae and $12 \%$ in C. regab). Vaccenic acid (18:1w7), another bacterial fatty acid often found in thiotrophic symbioses (Conway and McDowell Capuzzo, 1991; Ben-Mlih et al., 1992), only accounted for $3-5 \%$ of the fatty acids in both tissues. Markers of methanotrophic symbionts $(16: 1 \omega 8)$ were not found in C. regab and A. southwardae. A suite of bacterial fatty acids was found in negligible amounts, and probably accounted for sedimentary bacteria present on the surface of the tissues. A compound eluting with 20:4 13 dominated the PUFA composition. Although further derivatization is needed to confirm the position of the double bonds in this molecule, its fragmentation pattern supports its assignment as an isomer of 20:4 belonging to

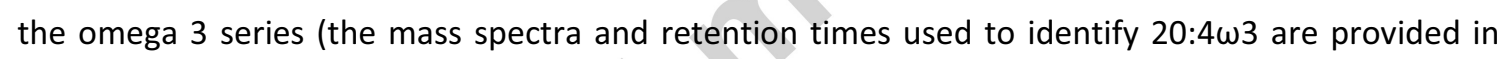
Appendix D). 20:4 43 accounted for more than $1 / 3$ of the fatty acids in the feet and was less

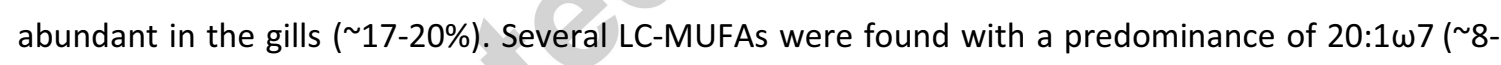
13\%). Saturated fatty acids (SAFAs) represented a minor fatty acid category $(<15 \%$ of the fatty acids), and were dominated by 16:0.

\section{Discussion}

\subsection{Nutritional quality of dietary sources in the Congo fan lobe complex}

Little is known on the dietary requirements of the abyssal fauna, but they are likely to be the same as for any animal. These fundamental needs include proteins (amino acids), lipids (fatty acids, sterols, fat), carbohydrates (sugars, starch), vitamins and diverse micronutrients. Proteins, lipids and carbohydrates are the principal dietary sources of carbon and serve as cellular energy fuel and building blocks for metabolic syntheses. For this reason, sedimentary contents in these three classes 
of biopolymers (i.e. the BPC) have been regarded as meaningful indication of food availability for deposit feeders in marine environments (Dell'Anno et al., 2002; Grémare et al., 2002; Isla et al., 2006; Neira et al., 2001; Rossi and Lardicci, 2002). BPC is usually low in deep-sea habitats (<4 mg BPC $\mathrm{g}^{-1}$ DW, Pusceddu et al., 2010), thereby limiting benthic communities. Sedimentary protein, carbohydrate and lipid concentrations are high in the distal lobe complex in comparison to values reported worldwide for deep-sea environments (Boetius et al., 1996; Danovaro et al., 1993; Pfannkuche and Thiel, 1987; Tselepides et al., 2000). BPC represents 22 to $34 \%$ of the OC pool at Site C and 24 to $67 \%$ at Site E (Fig. 6). At Site C, proteins are the dominant source of biopolymeric carbon, whereas lipids represent a minor component of the $\mathrm{OC}$ pool. The predominance of proteins over carbohydrates (PROT:CARB ratios $>1$ ) has been regarded as an indication of labile OM (Buscail et al., 1990) and input of fresh marine OM (Lee et al., 2004). However, the composition of sediments from the recent lobe matched closely the composition of sediments collected in the Congo River, which also exhibited high protein contents (Table 1). This suggests that PROT:CARB ratio is, in the present case, indicative of the terrestrial origin of the OM. The nearly conservative behaviour of the proteinaceous material during its export to the deep-sea implies it is relatively recalcitrant to degradation, or that the transfer is sufficiently fast for such material not to have the time to be decomposed.

At Site $\mathrm{E}, \mathrm{OC}$ content was low in the $0-7 \mathrm{~cm}$ horizon, but carbohydrate yields (> $2.5 \mathrm{mg} / \mathrm{g} \mathrm{OC}$ ) were consistently elevated in these layers and accounted for the high BPC in these hemipelagic deposits (>60\%, Pruski A.M., unpublished data). Such elevated BPC contents were unexpected since the sediments contain strongly altered planktonic detritus, as revealed by the dominance of marine amorphous matter and the presence of marine palynomorphs (Schnyder et al., submitted, this volume; Stetten et al., 2015). Although the cause of this observation is only speculative, marine snow may be enriched in polysaccharides and processes occurring during early diagenesis can substantially increase carbohydrate preservation in the sediments (Sinninghe Damsté et al., 1998). 
The high BPC content and contribution to the pool of total OC indicate that the distal lobe complex is characterised by trophic conditions typical of shelf environments (Neira et al., 2001). However, the abundance of BPC does not preclude that this pool of OM is bioavailable for the benthic fauna (Danovaro et al., 2001; Mayer et al., 1995). A closer look at THAA absolute content and monomeric composition provides further insight onto the lability of the available $\mathrm{OM}$ and on its nutritional relevance for the benthic fauna. THAA concentrations in sediment from the recent and abandoned lobe complex sites are elevated compared to those of the Atlantic abyssal plain (Grutters et al., 2001; Whelan, 1977). They are closer to the range of values reported for mangroves or sediments sampled within upwelling systems similar to those found off the Chilean coast (Jennerjahn and Ittekkot, 1997; Lomstein et al., 2006). THAA concentrations are lower in the disconnected Site E, pointing at turbidity currents as the principal source of proteinaceous material in the recent lobe. About one-third to two thirds of the nitrogen can be assigned to peptide-like material in the recent lobe complex. This is remarkably more than the $0.4 \%$ reported by Whelan (1977) for the Atlantic abyssal plain, but consistent with values reported on the NE Atlantic continental slope ( $30 \%$, Grutters et al., 2001) and the proportion of $\mathrm{T}_{\mathrm{AA}} \mathrm{N}$ in river sediments collected near Kinshasa ( $\sim 2 \%$, Table 1$)$. Although analytical differences among methods and laboratories must be considered, these striking differences are certainly related to the nature, history and inherent quality of the OM settling on the deep-sea floor. Most of the organic nitrogen in litter, mosses, soils and humic acids is immobilised in peptide-like materials (Knicker, 2004; Philben et al., 2016). Thereby, $\mathrm{T}_{\mathrm{AA}} \mathrm{N}$ often accounts for a large fraction of the nitrogen in sediments from river basins and coastal areas (Bourgeois et al., 2011; Dauwe et al., 1999b; Grutters et al., 2001; Zhao et al., 2016). In their study, Grutters and collaborators (2001) found that $\mathrm{OM}$ associated to the finest particles $(<0.5 \mu \mathrm{m})$ had higher $\% \mathrm{~T}_{\mathrm{AA}} \mathrm{N}$ and was less degraded than the coarser fraction. They also highlighted the continuous degradation of the OM attached to the particles during their down-slope transport. In contrast, the monomeric amino acid composition of the fluvial POC from the Congo River is barely altered during its transfer to the distal lobe complex (Fig. 7). This low reactivity may be attributed to the strong association of the amino acids with clay- 
size particles (Mayer et al., 2002) or their incorporation into refractory soil organic compounds (such as humic substances, Hsu and Hatcher, 2005), both mechanisms enabling the preservation of substantial amounts of amino acids. The reactivity index (RI) and the molar percentages of $\beta$-alanine and $y$-amino butyric acid give consistent and complementary indication on the diagenetic evolution of the $\mathrm{OM}$ in the distal lobe complex. Sediments from the recent lobes were slightly enriched in the non-proteic amino acids, $\beta$-alanine and $\gamma$-amino butyric acid, in comparison to the terrestrial endmembers, but RI and DI remained unaffected, except for Site E. Although these subtle changes are indicative of some degradation, the diagenetic alteration of the protein pool remains extremely limited in comparison to relict turbidite systems with deeply altered $\mathrm{OM}(\mathrm{DI}=-2.17, \mathrm{RI}=0.04$, Dauwe et al., 1999; Dauwe and Middelburg, 1998) and the prevalence of non-proteic amino acids (up to $35 \%$ of the amino acid pool, Cowie and Hedges, 1994). According to the vertical distribution of ${ }^{137} \mathrm{Cs}$, sediments deposited in the most distal reach of the active channel are recent (deposited after 1963, Stetten et al., 2015), which certainly explains their moderate degradation stage. In good consistence with this hypothesis, sediments in the abandoned lobe (Site E) are older and exhibit signs of more advanced degradation. The Congo River essentially exports strongly leached soil-OM and to a lesser extent well-preserved plant detritus (Spencer et al., 2012). In the distal lobe complex, terrestrial OM accounts for about 70\% of the total OM and is dominated by soil-OM (Stetten, 2015; Stetten et al., 2015). Taken together, these observations are consistent with the hypothesis that the rapid transfer of the continental POC along the Congo deep-sea channel enables THAA-rich material deriving from soils to reach the distal part of the Congo deep-sea fan and to escape remineralisation. This material has undergone considerable decay on the continent and only a small fraction of the amino acids are bioavailable for the benthic fauna (EHAA $10 \%$, Fig. B1 in Appendix B). Still, the turbidites represent a potentially labile source of food (high $\mathrm{OC}, \mathrm{BPC}$ and $\% \mathrm{~T}_{\mathrm{AA}} \mathrm{N}$ ) for the benthic fauna, which is adapted to less favourable trophic conditions.

Protein inputs, in particular, are nutritionally meaningful for the deep-sea fauna since dietary intakes of nitrogen represent the only source of nitrogen used by animals. In sediments, amino acids occur as 
more or less degraded proteinaceous material or are incorporated into humic substances, the latter being by far more refractory (Tenore et al., 1984). Considering the huge standing stock of proteaceinous material in the sediments, benthic organisms will withdraw enough amino acids despite the low digestibility of the OM delivered by the turbidity currents. Additional dietary sources may complement their nutrition, such as fresher OM from phytoplankton production (Soltwedel, 1997) or prokaryotes. In peculiar environments such as methane seeps, evidence supports the assumption that benthic microorganisms (bacteria and archaea) represent an important, nutritious food source for benthic invertebrates (Levin and Michener, 2002; Thurber et al., 2012). Methanederived carbon can represent more than half of the fixed carbon for fauna living in microbial mats, and $20-40 \%$ in vesicomyid or siboglinid fields (Decker and Olu, 2012; Levin and Mendoza, 2007). In ampharetid beds, these values vary between 6 and 100\% (Thurber et al., 2010). This contribution also increases with depth, due to lower availability of photosynthesis-derived material (Levin and Michener, 2002; Thurber et al., 2010). Although no gas bubbling has been observed above the seafloor in the distal lobes of the Congo deep-sea fan, methane diffusing through the sediment pore water fuels the benthic assemblages, and methane fluxes as high as in cold seeps (similar habitats) have been recorded by benthic chambers in vesicomyid beds (Khripounoff et al., 2015). Microbial communities composed of methane-oxidising bacteria (anaerobic and aerobic) are found in these habitats (Bessette, 2016; Pastor et al., 2017, this volume). White bacterial mats $\left(<1 \mathrm{~m}^{2}\right)$ certainly made of filamentous sulphide-oxidising bacteria and spots of black reduced sediments also occur sporadically in the recent lobes. These peculiar habitats are especially abundant in the relatively flat and wide depositional area of the recent lobe (Site C, see distribution in Sen et al., submitted, this volume). They form patches enriched in fatty acids by a four- to five-fold factor in comparison to the surrounding sediments (A.M. Pruski, unpublished) and constitute a cornucopia of food for the species adapted to reducing conditions and suphidic habitats.

\subsection{The detritus-based abyssal food web}


Due to the scarcity of labile organic matter in abyssal plains, benthic communities are usually food limited. Dense macrofaunal assemblages were found in non-reduced sediments from the lobe complex area (Olu et al., submitted, this volume). The increased abundance of organisms along the active channel (Sites A, F, C exhibit higher macrofauna densities than the abandoned Site E, Olu et al., this volume) shows that the benthic fauna exploits the labile organic substrates provided by the turbidity currents.

Holothurians represent important components of the abyssal megafauna both in terms of their abundance and functional role in the reprocessing of OM (Amaro et al., 2010; Billett, 1991; Sibuet et al., 1984). During the ROV surveys, holothurians of various morphologies were spotted crawling on bare sediments or swimming above the seafloor. The translucent holothurians observed and sampled in vesicomyid habitats and in their vicinity were slightly enriched in ${ }^{15} \mathrm{~N}$ and ${ }^{13} \mathrm{C}$ in comparison to the surrounding sediments, which is consistent with a surface deposit-feeding behaviour (Fig. 8). Although carbon and nitrogen isotopic values display little variability, the fatty acid patterns of two translucent holothurians (identified below by their sampling numbers, \#4 and \#5) reveal that members of this taxon exploit diverse diets in different habitats. Holothurian \#4 was collected inside a patch of dead clams. SAFAs were the prevalent fatty acids in its tegument, as expected, considering that the sedimentary OM available for detritus feeders was already degraded. Furthermore,

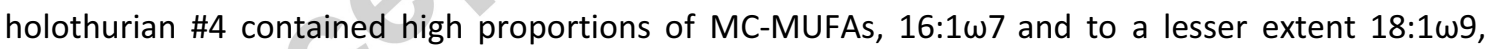

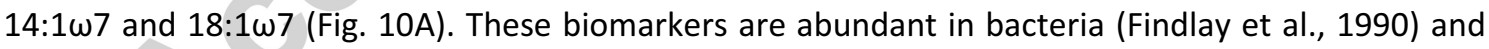
indicate reliance on bacterial dietary inputs. Specific biomarkers of bacteria accounted for approximately one fourth of the total fatty acids in the background sediments (Fig. 10C). Microbial biomass thus certainly contributes to the nutrition of the Congo deep-sea fan holothurians, as proposed for other deep-sea species (Amon and Herndl, 1991; Gao et al., 2014). The background sediments were characterised by a set of bacterial biomarkers that includes $3-\mathrm{OH}-14$, odd number and methylbranched fatty acids (Fig. 10C), while MUFAs were the dominant bacterial fatty acids in

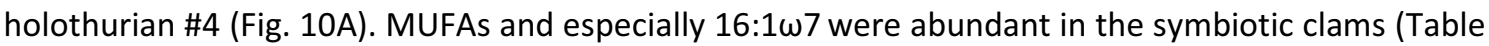


4) and in reduced sediments from the vesicomyid habitats (A.M. Pruski, unpublished data). The high MUFA content in holothurian \#4 is thus consistent with its sampling location (patch of dead clams) and indicates a selective feeding on reduced sediments, with a potential contribution from decaying tissues of clams. A scavenging behaviour has been previously suggested for the holothurid Chiridota sp. living in REGAB mytilid and vesicomyid beds (Olu et al., 2009; Fig. 5F). An additional source of bacterial fatty acids may be the bacterial communities present in the foregut and hindgut of holothurians (Gao et al., 2014). The other holothurian (\#5) was found on non reduced sediment. It was enriched in fatty acids and in particular in essential PUFAs (Fig. 10B) that were absent from the

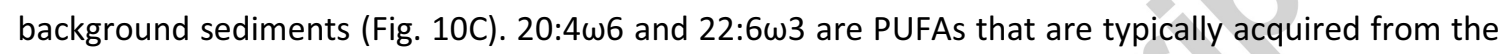
diet. They are found in phytoplankton, but are rapidly degraded as the rain of phytodetritus sinks to the abyssal floor (Kiriakoulakis et al., 2001). In the Porcupine plain, the high PUFA contents of some deep-sea holothurians have been linked to seasonal bentho-pelagic coupling and the competitive ability of some species to exploit this patchy high quality food (Hudson et al., 2004). However in other environments, the source of $20: 4 \omega 6$ and $22: 6 \omega 3$ used by the macrofauna is more likely autochthonous, due to low inputs from the water column (Kharlamenko et al., 2015). Piezophilic bacteria from sediments have been proposed as a source of PUFAs for the abyssal fauna, but their limited growth and activity in the natural environment generally prevent them from being significant providers of essential fatty acids for benthic consumers (for review, see Nichols, 2003). However, holothurians could assimilate PUFAs produced by the resident piezophilic communities living in their intestine (Nichols, 2003). Another proposed source of PUFAs for abyssal holothurians is the meiofauna (Kharlamenko et al., 2015). Bathysiphon sp., a giant abyssal foraminifer known to contain a high level of 20:4 $\omega 6$ (Gooday et al., 2002), forms large fields in the lobe complex area (Sen et al., submitted, this volume) and was abundant in the vicinity of holothurian \#5 (Fig. 5C). Although it is unlikely that detritus feeders can predate directly on large preys, they could assimilate the decaying foraminifer tissues incorporated in the sediments. In the absence of taxonomic identification, the differences between the two translucent holothurians are only speculative. Yet, isotopic signatures 
and fatty acid patterns confirm that the translucent holothurians are mobile superficial sediment

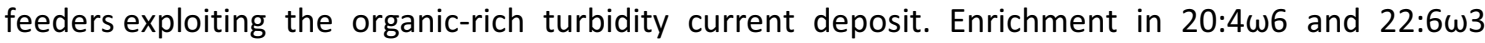
highlights some selectivity for sources enriched in PUFAs (bacteria or meiofauna), but biochemical differences linked to physiological state cannot be excluded. The swimming purple holothurian was noticeably enriched in ${ }^{15} \mathrm{~N}$ compared to the other holothurians $(+5.8 \%)$ and the background sediments $(+9.6 \% \circ)$, which suggests the use of a distinct detrital food source. Together these results highlight a certain degree of particle selectivity and food partitioning among holothurians.

Other prominent members of the megafauna in abyssal ecosystems are poriferans, which rely on the rain of POM and may compete with deposit-feeders for resuspended sediments (Lampitt, 1985). The range of $\delta^{13} \mathrm{C}$ and $\delta^{15} \mathrm{~N}$ values in poriferans was very narrow, suggesting little variability in the food source available for these sessile suspension-feeders. Poriferans were not found along the active channel or in areas receiving inputs from turbidity currents (Sites A, F, C and B). The three species were collected at Site $\mathrm{E}$, which is located $45 \mathrm{~km}$ North of the active channel and receives hemipelagic inputs $\left(\delta^{13} \mathrm{C}=-24.21 \pm 1.40\right.$ and $\delta^{15} \mathrm{~N}=+7.14 \pm 0.75$, Table 1$)$. The isotopic signature of particles from traps deployed at the REGAB site, located $8 \mathrm{~km}$ North of the Congo deep-sea channel at a $3,200 \mathrm{~m}$ depth, was $\delta^{13} \mathrm{C}=-23.22 \%$ and $\delta^{15} \mathrm{~N}=+4.43 \%$ (Olu et al., 2009), consistent with the average $\delta^{13} \mathrm{C}$ signature of sedimentary OM collected in the distal lobe complex area $(-23.70 \% \pm 0.42$, Baudin et al., 2017, this volume). The ${ }^{13} \mathrm{C}$ and ${ }^{15} \mathrm{~N}$ enrichment of the three sponges suggests they do not directly rely on sedimentary POM or resuspended sediments $\left(+4.7 \%\right.$ of ${ }^{13} \mathrm{C}$ and $+9.1 \%$ of ${ }^{15} \mathrm{~N}$ vs sediment), but rather on other sources with higher $\delta^{15} \mathrm{~N}$, as observed in poriferans from the Porcupine abyssal plain (Iken et al., 2001). Such high $\delta^{15} \mathrm{~N}$ may be attributed to symbiotic bacteria metabolising refractory OM (Iken et al., 2001) or to a certain extent to a carnivorous behaviour (ingestion of small preys by these microphagous suspension feeders). Dietary inputs from these two sources are supported by the high contributions of bacterial biomarkers in the three individuals, the abundance of zooplankton biomarkers (LC-MUFAs) in the thorny and yurt-shaped sponges and a high

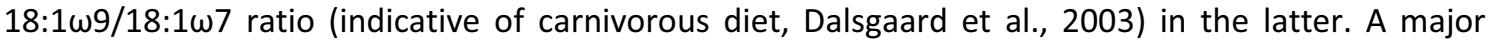


feature of sponges from the Congo deep-sea fan was their enrichment in PUFAs (48-67\%). Most marine organisms are unable to synthesise de novo PUFAs, and may only contribute to trophic upgrading (i.e. the conversion of dietary PUFAs to longer PUFAs, Monroig et al., 2013). This represents a major ecological constraint for abyssal suspension-feeders, as external sources of PUFAs are limited. At this depth, suspended particulate matter is an unlikely dietary source of essential fatty acids due to intensive degradation in the water column. Yet, sponges have unusual pathways of PUFA biosynthesis with active desaturation and elongation systems (Monroig et al., 2013). In addition, bacteria producing PUFAs have been isolated from sponges (Patnayak and Sree, 2005). They could

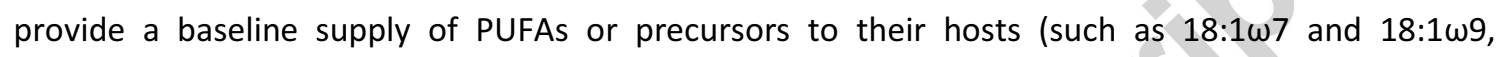
previously identified in associate bacteria, Patnayak and Sree, 2005). Although the respective functions of the two partners are still unknown, the sponge holobionte appears highly efficient at biosynthesising PUFAs essential to maintain membrane fluidity in abyssal systems. Noteworthy, the constant $20: 5 \omega 3 / 20: 4 \omega 6$ ratio (1.8) in the investigated sponges suggests some homeostatic regulation (i.e. membrane composition). Numerous amphipods were found in the yurt-shaped sponge that could provide a refuge from predation and a direct or indirect source of nutrition. The very similar fatty acid composition of the amphipods and their host (Fig. 9) suggests that they feed to some extent directly on the sponge. This is possible since spicules have been previously observed in the gut of sponge-associated amphipods (Amsler et al., 2009). Alternatively, the amphipods could graze the associate bacteria.

Finally, the bulk carbon and nitrogen signatures of an actinarian collected on a hard sediment block from Site B indicates that a suspension-feeder from another phylum exploits a resource similar to the one used by sponges.

\subsection{Thiotrophic symbioses in areas of enhanced anaerobic methane oxidation}

All along the active channel, aggregates of vesicomyid clams in areas of reduced sediment provide biogenic habitats resembling those found on the methane pockmark REGAB located ca. $200 \mathrm{~km}$ 
upstream the turbiditic channel and $8 \mathrm{~km}$ North of the Congo deep-sea canyon (Olu et al., 2009; OluLe Roy et al., 2007).

The light carbon isotopic signature in the gills of the two vesicomyid bivalve species, $C$. rega $b$ and $A$. southwardae, is consistent with the presence of thiotrophic endosymbionts in this tissue, as previously confirmed using molecular and FISH methods (Decker et al., 2013 and unpublished data). Symbiotic clams have a very reduced digestive system and thus depend solely on their symbionts for their nutrition. In chemoautotrophic symbioses, the carbon fixed by the symbionts may be transferred to the host by two non-exclusive mechanisms known as milking (translocation of small soluble organic molecules excreted by the symbionts) and farming (the direct digestion of the bacterial cells). Many clues suggest that in vesicomyids, farming is the preferential process for carbon translocation from bacteria to host (Albéric et al., 1995; Childress and Girguis, 2011; Fiala-Médioni and Le Pennec, 1988; Newton et al., 2007). The negative $\delta^{13} \mathrm{C}$ values in the symbiont-free mantle tissue confirm carbon translocation from the gills to the host (Fig. 8). The observed enrichment in ${ }^{13} \mathrm{C}$ and ${ }^{15} \mathrm{~N}$ between the gills and the mantle is consistent with the fractionation pattern usually observed between an organism and its diet $\left(<1 \%\right.$ and $3.2 \%$ enrichment of ${ }^{13} \mathrm{C}$ and ${ }^{15} \mathrm{~N}$ vs. diet, Michener and Kaufman, 2007) and could be due to fractionation occurring when the bacterial constituents are assimilated by the host. This trend however was not verified for the $\delta^{13} \mathrm{C}$ signature of $C$. regab at Site $\mathrm{F}$, suggesting a different fractionation pattern, or the assimilation of an additional source of carbon depleted in ${ }^{13} \mathrm{C}$ (diffusion of DOC through the biological membranes or ingestion of bacteria and/or archaea with depleted carbon signature).

Between-site differences were observed, with lighter $\delta^{13} \mathrm{C}$ signatures at Site $\mathrm{C}$ and heavier signatures at Site A (Fig. 8). This heterogeneity reveals that the signature of the bicarbonate source used by the symbionts is variable. Chemoautotrophic sulphide-oxidising bacteria are greatly depleted relative to the ambient carbon source $\left(-24.6\right.$ to $-25.1 \%$, Ruby et al., 1987). Considering an average $\delta^{13} \mathrm{C}$ of $-43.2 \%$ in $C$. regab at Site $C$ and a fractionation factor of $-25 \%$, the estimate $\delta^{13} C$ of the DIC source is $-18.2 \%$ for this site, which is comparable to values reported for interstitial DIC in the Gulf of Mexico 
(Coffin et al., 2015). These light DIC signatures may be explained by the production of ${ }^{13} \mathrm{C}$-depleted $\mathrm{CO}_{2}$ during anaerobic methane oxidation (Coffin et al., 2015). We may hypothesise that higher OM inputs (i.e. higher sedimentation rates) in the main depositional area (Site C) lead to more intensive methane oxidation (aerobically and anaerobically) and thus to higher $\mathrm{DIC}{ }^{13} \mathrm{C}$-depletion. In contrast, more homogenous $\delta^{13} \mathrm{C}$ signatures were observed among $C$. regab at the REGAB pockmark (this study, Fig. 8 and Olu et al., 2009). In good constancy with our hypothesis, the different clam patches were characterised by similar sediment geochemistry and AOM activity (Pop Ristova et al., 2012), suggesting the bicarbonate source remained the same across the REGAB pockmark.

Tissues of vesicomyids also recorded processes affecting nitrogen cycling in the sediments. Vesicomyids were indeed remarkably depleted in ${ }^{15} \mathrm{~N}(-6.4$ to $-18.8 \%$ ), but even lower values have been reported for bathymodiolid mussels from hydrocarbon seepages on the Louisiana slope and in the Gulf of Mexico (Becker et al., 2010; Duperron et al., 2007). Values in C. regab were furthermore low in comparison to the $\delta^{15} \mathrm{~N}$ signatures of individuals collected from the REGAB pockmark $(3.5 \% \pm \pm$ $1.9 \%, n=35$ analyses; this study and Olu-Le Roy et al., 2007). Vesicomyid clams strictly rely on chemoautotrophy to meet all their nutritional requirements. Thereby, inorganic nitrogen assimilation is critical to their metabolism (Lee et al., 1999). The sources of nitrogen assimilated by these organisms include ammonia, nitrates and sometimes nitrites (Kuwahara et al., 2007; Lee et al., 1999; Newton et al., 2007). No data is available regarding the isotopic composition of the various inorganic nitrogen end-members, but high ammonia fluxes linked with denitrification and excretion were measured at Site C (Khripounoff et al., 2015). Moreover, a previous study at REGAB pockmark also revealed high ammonia concentrations close to the foot of bivalves (Pop Ristova et al., 2012), indicating ammonia could be an important nitrogen source for the vesicomyids. High ammonia concentrations at the sediment water interface lead to preferential incorporation of ${ }^{14} \mathrm{~N}$ over ${ }^{15} \mathrm{~N}$ (MacAvoy et al., 2003). When ammonia or nitrate is in excess, a strong nitrogen isotopic fractionation $(\sim-13 \%)$ is observed during the assimilation of inorganic nitrogen to amino acids via the glutamine synthetase pathway (Macko et al., 1987). This fractionation is not observed in normal 
conditions when inorganic nitrogen is completely used. The isotopic signature of vesicomyids thereby suggests higher inorganic nitrogen (likely ammonium) concentrations in the distal lobe complex than at the REGAB pockmark. Ammonium concentrations in the sediments are indeed elevated (between 1500 and $2000 \mu \mathrm{M}$, Taillefert et al., this volume) and largely above the ammonium levels measured at REGAB (Pop Ristova et al., 2012). In addition, A. southwardae had a lighter nitrogen isotopic composition than $C$. regab, suggesting either different fractionation patterns in the two species or the use of different nitrogen sources. Indeed, although it is a less efficient electron acceptor, nitrate can be used as an energy source by symbionts (Hentschel and Felbeck, 1993; Kuwahara et al., 2007; Newton et al., 2007; Wilmot and Vetter, 1992). The gene necessary for nitrate respiration is present in the symbionts of some vesicomyid bivalves and absent in others (Kuwahara et al., 2007; Newton et al., 2007). So, differences in the genome of the symbionts of $C$. regab and $A$. southwardae could explain the use of different nitrogen sources. Moreover, A. southwardae is longer than C. regab and possesses haemoglobin, assumed to facilitate digging more deeply in the sediments (Decker et al., submitted, this volume; Krylova et al., 2010). Hence, it could have access to higher amounts of dissolved inorganic nitrogen or a deeper pool of inorganic nitrogen. Similar observations have been made at the REGAB pockmark, where two species also co-occurred, C. regab and L. chuni. The latter can also bury deeper in the sediment due to longer siphons and different oxygen carriers (Decker et al., 2014; Krylova et al., 2010), and also possesses lighter ${ }^{15} \mathrm{~N}$ signature than C. regab (this study, Fig. 8).

As a preliminary approach to study the trophic link between the symbionts and their host, further biomarker investigations were conducted on a patch where both species coexist (Site F). In the vesicomyid gills, the bacterial symbionts take most of the volume of the bacteriocytes (50 to $76 \%$ of the gill epithelial cell volume, Decker et al., 2013 and unpublished data). Their phospholipid composition is closely related to that of free living sulphide-oxidising bacteria with high amounts of MUFAs, $16: 1 \omega 7$ and $18: 1 \omega 7$ (63 to $78 \%$ of the total fatty acids, Conway and McDowell Capuzzo, 1991). The high amounts of these two biomarkers in the gills of $C$. regab and $A$. southwardae (>50\%) 
is almost certainly related to the composition of the symbiont membranes, whereas the high level of $16: 1 \omega 7$ in the symbiont-free tissues (foot) demonstrates the translocation of bacterial fatty acids and the importance of the symbiosis in the nutrition of the vesicomyids. Apart from the symbiont biomarkers, only a very limited number of fatty acids were identified in significant amounts in the two vesicomyid species. This contrasts with the diversity of trophic biomarkers usually found in filterfeeding bivalves, whose composition closely reflects the phytoplanktonic community in their environment. Although PUFA content was high in C. regab and A. southwardae, it was nearly exclusively made of a compound eluting with the same retention time as 20:4 33 (see Fig. D1 in Appendix D). The occurrence of unusual and even new unsaturated fatty acids is a singular particularity of many symbiotic clams (Allen et al., 2001; Ben-Mlih et al., 1992; Saito, 2007). 20:4w3 is

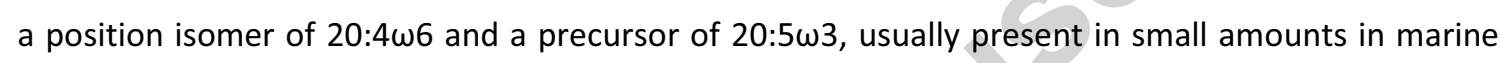
invertebrates. Eicosanoids derive in animals from elongation and desaturation of dietary precursors

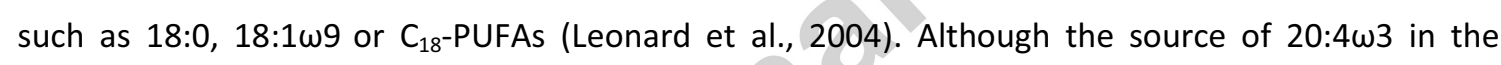
symbiosis remains unknown, vesicomyids could synthesise it from bacterial 18:1w9 (Leonard et al., 2004). The absence of PUFAs, usually considered as essential for marine organisms (20:5w3 and 22:6 63 ), suggests that $20: 4 \omega 3$, and possibly NMID that were not investigated in the present study, act as surrogates insuring membrane fluidity and other fundamental metabolic functions (prostaglandin synthesis, reproduction, stress response, etc.).

\subsection{Contribution of chemosynthesis to the heterotrophic fauna in the vesicomyid habitats}

Within the vesicomyid habitats, the associated fauna composed of surface or sub-surface feeding annelids (Ampharetidae and Dorvilleidae), epicommensal suspension-feeding actinarians and opportunist galatheids exhibited a distinctively light carbon isotopic signature highlighting the utilisation of chemosynthetically-derived OM. These organisms could either directly ingest sulphideoxidising bacteria, smaller-size fauna (meiofauna) relying on sulphide-oxidising or methanotrophic bacteria, or rely on the tissues and solid wastes of vesicomyids. The most depleted $\delta^{13} \mathrm{C}$ signatures 
could be indicative of some reliance on methane-derived carbon in polychaetes with different niches for ampharetids $(-38.9 \pm 1.39 \%$ ) and dorvilleids $(-48.1 \pm 2.9 \%$ o). Symbiosis has not been investigated, but nutrition based on aerobic methanotrophic bacteria has been suggested for dorvilleids at cold seeps (Decker and Olu, 2012) and archivory (involving methanotrophic archaea) has been demonstrated (Thurber et al., 2012). As for ampharetids, they have been suggested to preferentially rely on aerobic methanotrophs, but also on sulphide oxidisers and sulphate reducers (Thurber et al., 2013). Aerobic methanotrophic bacteria as well as anaerobic methanotrophic archaea have been evidenced in sediments collected in vesicomyid aggregates from the Congo fan lobe complex (Bessette, 2016; Pastor et al., 2017, this volume). High fluxes of $\mathrm{CH}_{4}$ were measured in the vesicomyid habitats (Khripounoff et al., 2015). This methane certainly has a biogenic origin with an isotopic signature ranging from $-70 \%$ o to $-90 \%$ (Pastor et al., 2017, this volume). We estimated that methanederived carbon contributed to about 21 to $46 \%$ of the diet in dorvilleids and 2 to $29 \%$ in ampharetids, which confirms the different feeding preferences of the two taxa and can also explain their spatial distribution. Ampharetids are tube-building polychaetes that dominate in the vesicomyid assemblages (Fig. 5D). They are surface deposit-feeders gathering food particles with their long tentacles. They are likely to feed on the detrital OM deposited on the surface as well as on the heterotrophic and chemosynthetic bacteria, which explains their lower reliance on methanotrophy. In constrast, dorvilleids dominate in areas of black reduced sediments but were also abundant in the white microbial mats, where sulphide peak is more superficial, and AOM certainly occurs at lower depth. Dorvilleids are mobile omnivores with chitinised jaws well-adapted to graze microbial biomass and aggregates that perform AOM. More insight into the diet of the dorvilleid worms can be gained from fatty acid biomarkers. In particular, bacterial fatty acids have been previously traced in these polychaetes (Salvo et al., 2015; Thurber et al., 2013, 2012). The fatty acid profile of the dorvilleids from the Congo fan lobe complex was consistent with a diet mainly based on bacteria (Table 4). In a similar way as their congeners from Costa Rica seeps (Thurber et al., 2012), they contained two unusual bacterial fatty acids of the omega 5 series, $16: 1 \omega 5$ and $18: 1 \omega 5$ (1.3 to $3.1 \%$ ). Whereas 
Eukaryotes may synthesise $18: 1 \omega 5$ by elongation of $16: 1 \omega 5$, the latter is specific of sulphate-reducing bacteria (SRB) belonging to the Desulfobacteraceae family (Elvert et al., 2003) and is diagnostic of anaerobic methane-oxidising (AOM) consortia. The light $\delta^{13} \mathrm{C}$ signature and the incorporation of SRB markers clearly confirm that dorvilleids from the Congo fan lobe complex consume anaerobic methanotrophic archaea (ANME) and SRB aggregates. Another possible indication of the ingestion of SRB by the dorvilleids is the high contribution of $18: 1 \omega 7$, which is commonly found in AOM consortia (Thurber et al., 2013). Yet, inputs of 18:1w7 deriving from sulphide-oxidising bacteria (McCaffrey et al., 1989) are equally possible in these sulphide-rich environments. In other methane seeps such as those located along New Zealand's North Island, the heterotrophic fauna inhabiting ampharetid beds was shown to rely mainly on aerobic bacterial methanotrophs. This is not the case for the dorvilleids from the Congo fan lobe complex since diagnostic fatty acid biomarkers for these bacteria, 16:1w6 and 16:1w8 (Bowman et al., 1991), were not found.

Finally, all the associated fauna in the vesicomyid habitats exhibited light nitrogen isotopic signatures related to the detritic $\mathrm{OM}$ and the fauna inhabiting the adjacent non-reduced sediments. This clearly indicates that they use a local microbial source of organic nitrogen. The two actinarians collected on the shells of living clams and their congeners collected on bare sediments had distinct carbon isotopic signatures (Fig. 8). The epicommensal actinarians had $\delta^{13} \mathrm{C}$ signatures (-31.5 \%) similar to that of the Ampharetidae, but remarkably enriched related to their host ( $+6.4 \%$ o shift). This suggests primarily feeding on fine particles and bacteria resuspended by the biological activity of the host.

\subsection{Synthesis: Link between turbidites, engineering vesicomyids and chemosynthesis-based}

\section{communities}

Soft-sediment communities fuelled by chemoautotrophy have been found in many kinds of deep-sea settings where reducing conditions prevail (Bernardino et al., 2012). These include sediments covering basalt deposits in areas of hydrothermal venting, subduction zones and methane cold seeps. Enhanced fluid flow enables the delivery of the inorganic reduced chemicals (sulphide, 
methane) used by the resident chemoautotrophs in these habitats. Similar communities are also observed in the vicinity of decaying massive organic falls (mammals, woods, etc.), but are unusual in organic-rich depositional areas. So far, chemosynthetic communities only have been reported in the Laurantian fan (Mayer et al., 1988) and Monterey fan valley (Embley et al., 1990), where their occurrence is attributed to the re-exposition of older sediment strata. In both cases, the establishment of these communities is explained by the long-lasting environmental stability that has followed the latest mass deposit event ( $\sim 50$ years in the Laurantian fan and $\sim 100$ years in the Monterey valley; Mayer et al., 1988; Paull et al., 2010). The Congo deep-sea fan differs by the frequency of turbiditic currents ( 2 years, Heezen et al., 1964) and the fact that vesicomyid habitats are common all along the active channel of the lobe complex. The aim of this study was to elucidate feeding strategies in macrofaunal assemblages from the distal lobe complex of the Congo deep-sea fan as part of a greater effort to understand the link between the inputs of terrestrially-derived OM and the chemosynthetic habitats. Sedimentary $\mathrm{OM}$ is abundant, rich in biopolymeric compounds, and nitrogen occurs mainly as proteacinous material. In addition, the development and growth of benthic organisms is not limited by essential molecules, which can be found either directly in the soilderived OM (rich in essential amino acids) or following the reprocessing of refractory compounds by resident microbes or meiofauna (PUFA production). Sedimentary OM is thereby abundant and of sufficiently good quality to fulfill the nutritional needs of benthic invertebrates. Macrofaunal densities were found to be much higher than is usually the case at similar depth. The fauna was dominated by polychaetes, as usual for deep-sea macrofauna, or by peracarid crustaceans (tanaidaceans, isopods). The dominance of polychaetes of the Cossuridae family on the levee sediments was related to the high organic content of the sediment (Olu et al., submitted, this volume). These high abundances clearly indicate that biogenic inputs from the Congo River are a trophic driver of macrofaunal density in this system.

The intensive ROV survey conducted during WACS and Congolobe revealed the presence of numerous patches of reduced black sediments with some being associated to microbial mats and/or vesicomyids 
(Sen et al., submitted, this volume). The processes explaining the onset of these peculiar habitats and their spatial distribution remain largely unknown, but they result in the upward diffusion of methane and sulphide (Pastor et al., 2017, this volume). A striking feature is the abrupt change in the porewater geochemistry observed between the vesicomyid habitats and the adjacent background sediments (at the scale of a few decimetres, see Figs. 2D and E). Although their precise role in the chemosynthetic community succession needs further consideration, symbiotic clams act as foundation species in the Congo fan lobe complex and create localised biogenic habitats in areas of reduced sediments. The metabolism of the vesicomyids is strongly tied to microbial consortium performing methane oxidation and sulphate reduction to sulphide (Boetius et al., 2000), the energetic substrate that fuels symbiosis. In the lobe complex, methane arises from OM degradation by methanogens, which leads to the buildup of methane in the porewater (Pastor et al., 2017, this volume). This process certainly occurs at a relatively shallow depth in the sediment (Pastor et al., 2017, this volume), allowing sulphide-tolerant polychaetes (dorvilleids) to forage on the AOM consortia. The OM in the reduced sediments has the same terrestrial origin as in the background seafloor (Baudin et al., 2017, this volume). The chemosynthetic habitats are thus directly controlled by the biogeochemical recycling of the OC-rich turbidity current deposits. Clams actively delve down in the sediments with their muscular foot to pump the porewater sulphide, thereby creating diffusive gradients. They rework and bioirrigate the sediments, allowing deeper penetration of diffuse oxygen, and certainly favour the reoxidation of anaerobic degradation products (Fischer et al., 2012; Levin, 2005). The texture of the sediments was also more granular and less consolidated than in the adjacent sediments (G. Vétion, Pers. Obs). Microbial communities are likely to be impacted by the modifications of their chemical and physical environment. For instance, in coastal sediments macrofaunal activity stimulates lipid degradation (Sun et al., 1999), whereas in cold seeps vestimentiferans increase sulphide production in the sediments by releasing sulphate through their roots (Cordes et al., 2005). The efficient OM remineralisation measured inside the biological aggregates (Pozzato, submitted, this volume) is a clear clue of the engineering role of the bivalves on the microbial consortium involved in OM reprocessing. Higher OC 
contents, lower $\mathrm{C} / \mathrm{N}$ ratios and more depleted $\delta^{13} \mathrm{C}$ signatures in surface sediments are further indications of the importance of these local microbial communities close to the vesicomyids (Baudin et al., 2017, this volume). The isotopic signatures of the Ampharetidae and Dorvillidae clearly indicate that the dominant heterotrophic taxa in the vesicomyid habitats benefit from this local microbial resource and selectively or partially forage on chemosynthetic bacteria. Although no large predator has been captured during the two field campaigns, zoarcid fish were spotted in the chemosynthetic habitats, suggesting some trophic transfer to higher levels of the abyssal food web. Sampling of hemipelagic fish using beam trawls at increasing distance from the REGAB pockmark has evidenced a significant export of chemosynthetically fixed carbon to the surrounding ecosystem. Chemosynthetic carbon was estimated to contribute at least $35 \%$ to the diet of the zoarcid fish but the species was not sampled outside of the pockmark (Olu et al., 2009). Further investigations are necessary to assess how chemosynthetic habitats found in the distal lobe complex of the Congo deep-sea fan influence the surrounding abyssal plain.

\section{Conclusions}

The aggregates of vesicomyid bivalves from the Congo deep-sea fan represent one rare example of a soft-sediment, chemosynthetically based ecosystem sustained by the diagenesis of organic-rich turbidity current deposits. These exceptional OM inputs at such abyssal depths also sustain a more classical detritus-based ecosystem. Sedimentary OM, the principal dietary source, is mostly soilderived, poorly digestible and relatively refractory due to extent degradation on the continent. However, the standing stock of bioreactive carbon is huge and of sufficient quality to support dense assemblages of macrofauna. The reprocessing of OM by methanogens leads to the build-up of methane in the porewater sediment. Oxidation of methane coupled to sulphate reduction provides the necessary reduced substrates for chemosynthesis. Vesicomyidae relying on thiotrophic endosymbionts benefit from these conditions and create biogenic habitats that increase ecosystem heterogeneity in the recent lobe complex. Within these assemblages, the heterotrophic fauna relies 
on chemosynthesis, allowing the transfer of energy from the terrestrial OM accumulated in the sediments to the abyssal food web. Primary consumers such as dorvilleid polychaetes directly graze chemosynthetic free-living microorganisms, whereas the depleted and more variable $\delta^{15} \mathrm{~N}$ of ampharetids, galatheids and actinarians suggests a reliance on OM recycled by local microbial communities. In the surrounding sediments, surface detritivorous holothurians feed on sedimentary $\mathrm{OM}$, while a more degraded pool of $\mathrm{OM}$ is exploited by suspension-feeding poriferans and an isolated actinarian. In the Congo deep-sea fan, bacteria are major actors in the transfer of the terrestrial OM to the abyssal food web at any given trophic level, as free-living heterotrophic or chemosynthetic microorganisms involved in the recycling of $\mathrm{OM}$, as associate microfauna contributing to the metabolisation of refractory $\mathrm{OM}$ or as endosymbionts fulfilling the nutritional needs of vesicomyids. Noteworthy, whereas most benthic invertebrates from the Congo deep-sea fan are enriched in essential fatty acids of the omega 3 and 6 series, the prevalent PUFAs differed among species, revealing distinct strategies to assimilate and retain dietary intakes or to biosynthesise them from precursors or through bacterial associates.

\section{Acknowledgments}

We are indebted to Ifremer/Genavir, the captain (G. Ferrand), C. Rabouille as chief scientist of the Congolobe cruise, and crews for the sampling campaigns WACS and Congolobe onboard the R/V Pourquoi Pas? We acknowledge S. Bourgeois for sample conditioning during the Congolobe campaign and B. Bombled and P. Noel, who were in charge of the multicore sampling during the cruises. We are grateful to J. Caparros and O. Crispi who kindly performed elemental analyses on the river samples, S. Hourdez, P. Bonifacio, M. Sibuet and E. Mac Phearson for taxomomic identification, E.J. Pernet for sample preparation for isotopic analyses, and H. Wang for assistance with the biochemical analyses. We are thankful to R. Spencer and H. Talbot for providing samples from the Congo River. We also want to thank K. Debbasch (Paris Descartes University, Maison des Langues) for 
the English editing of the manuscript, J. Tourolle for her assistance with the high resolution

bathymetric maps and V. Domien for her help with the design of the figures.

This work was supported by the ANR grant Congolobe led by C. Rabouille (ANR-11-BS56-0030, 2011-

2016). The study also benefited from financial supports from the Institute of Ecology and

Environment (INEE CNRS and University Paris VI) to UMR8222 LECOB, as well as from IFREMER to the

"Laboratoire Environnement Profond". E. Stetten was supported by a doctoral fellowship from the

French Ministry of Research and Education.

\section{References}

Albéric, P., Fiala-Médioni, A., Boulègue, J., 1995. Free diaminopimelic acid in symbiotic bivalves. Comptes Rendus Acad. Sci. Ser. III-Sci. Vie-Life Sci. 318, 1053-1057.

Alkhatib, M., Schubert, C.J., del Giorgio, P.A., Gélinas, Y., Lehmann, M.F., 2012. Organic matter reactivity indicators in sediments of the St. Lawrence Estuary. Estuar. Coast. Shelf Sci. 102103, 36-47. doi:10.1016/j.ecss.2012.03.002

Allen, C.E., Tyler, P.A., Van Dover, C.L., 2001. Lipid composition of the hydrothermal vent clam Calyptogena pacifica (Mollusca : Bivalvia) as a trophic indicator. J. Mar. Biol. Assoc. U. K. 81, 817-821. doi:10.1017/S0025315401004647

Amaro, T., Bianchelli, S., Billett, D.S.M., Cunha, M.R., Pusceddu, A., Danovaro, R., 2010. The trophic biology of the holothurian Molpadia musculus: implications for organic matter cycling and ecosystem functioning in a deep submarine canyon. Biogeosciences 7, 2419-2432. doi:10.5194/bg-7-2419-2010

Amon, R.M.W., Herndl, G.J., 1991. Deposit feeding and sediment: Mar. Ecol. 12, 163-174. doi:10.1111/j.1439-0485.1991.tb00250.x

Amsler, M.O., McClintock, J.B., Amsler, C.D., Angus, R.A., Baker, B.J., 2009. An evaluation of spongeassociated amphipods from the Antarctic Peninsula. Antarct. Sci. 21, 579-589.

Babonneau, N., Savoye, B., Cremer, M., Bez, M., 2002. Processes and sedimentary architectures along the present Zaire turbidite channel (ZAIANGO project). AAPG Annu. Meet. Abstract A11.

Badawy, A.A.-B., 2012. The EZ:Faast family of amino acid analysis kits: application of the GC-FID kit for rapid determination of plasma tryptophan and other amino acids. Methods Mol. Biol. Clifton NJ 828, 153-164. doi:10.1007/978-1-61779-445-2_14

Barnes, H., Blackstock, J., 1973. Estimation of lipids in marine animals and tissue: detailed investigations of the sulfovanillin method for total lipids. J. Exp. Mar. Biol. Ecol. 12, 103-118.

Baudin, F., Disnar, J.R., Martinez, P., Dennielou, B., 2010. Distribution of the organic matter in the channel-levees systems of the Congo mud-rich deep-sea fan (West Africa). Implication for deep offshore petroleum source rocks and global carbon cycle. Mar. Pet. Geol. 27, 995-1010.

Baudin, F., Stetten, E., Schnyder, J., Charlier, K., Martinez, P., Dennielou, B., Droz, L., 2017. Origin and distribution of the organic matter in the distal lobe of the Congo deep-sea fan - A Rock-Eval 
survey. Deep Sea Res. Part II Top. Stud. Oceanogr., this volume. http://dx.doi.org/10.1016/j.dsr2.2017.01.009

Becker, E.L., Lee, R.W., Macko, S.A., Faure, B.M., Fisher, C.R., 2010. Stable carbon and nitrogen isotope compositions of hydrocarbon-seep bivalves on the Gulf of Mexico lower continental slope. Deep Sea Res. Part II Top. Stud. Oceanogr. 57, 1957-1964. doi:10.1016/j.dsr2.2010.05.002

Ben-Mlih, F., Marty, J.C., Fiala-Médioni, A., 1992. Fatty-acid composition in deep hydrothermal vent symbiotic bivalves. J. Lipid Res. 33, 1797-1806.

Bernardino, A.F., Levin, L.A., Thurber, A.R., Smith, C.R., 2012. Comparative composition, diversity and trophic ecology of sediment macrofauna at vents, seeps and organic Falls. PLoS ONE 7, e33515. doi:10.1371/journal.pone.0033515

Bessette, S., 2016. Identification des communautés microbiennes des lobes terminaux du système turbiditique du Congo. Université de Brest.

Billett, D.S.M., 1991. Deep-sea holothurians. Oceanogr. Mar. Biol. Annu. Rev. 29, 259-317.

Boetius, A., Ravenschlag, K., Schubert, C.J., Rickert, D., Widdel, F., Gieseke, A., Amann, R., Jørgensen, B.B., Witte, U., Pfannkuche, O., 2000. A marine microbial consortium apparently mediating anaerobic oxidation of methane. Nature 407, 623-626. doi:10.1038/35036572

Boetius, A., Scheibej, S., Tselepides, A., Thiel, H., 1996. Microbial biomass and activities in deep-sea sediments of the Eastern Mediterranean: trenches are benthic hotspots. Deep Sea Res. Part I Oceanogr. Res. Pap. 43, 1439-1460. doi:10.1016/S0967-0637(96)00053-2

Bourgeois, S., Pruski, A.M., Sun, M.-Y., Buscail, R., Lantoine, F., Kerhervé, P., Vétion, G., Rivière, B., Charles, F., 2011. Distribution and lability of land-derived organic matter in the surface sediments of the Rhône prodelta and the adjacent shelf (Mediterranean Sea, France): a multi proxy study. Biogeosciences 8, 3107-3125. doi:10.5194/bg-8-3107-2011

Bowman, J.P., Skerratt, J.H., Nichols, P.D., Sly, L.I., 1991. Phospholipid fatty acid and lipopolysaccharide fatty acid signature lipids in methane-utilizing bacteria. FEMS Microbiol. Lett. 85, 15-22. doi:10.1111/j.1574-6968.1991.tb04693.x

Buscail, R., Pocklington, R., Daumas, R., Guidi, L., 1990. Fluxes and budget of organic matter in the benthic boundary-layer over the Northwestern Mediterranean Margin. Cont. Shelf Res. 10, 1089-1122.

Childress, J.J., Girguis, P.R., 2011. The metabolic demands of endosymbiotic chemoautotrophic metabolism on host physiological capacities. J. Exp. Biol. 214, 312-325.

doi:10.1242/jeb.049023

Clarke, K.R., Gorley, R.N., 2006. PRIMER v5: users manual/tutorial. PRIMER-E Ltd, Plymouth.

Coffin, R., Osburn, C., Plummer, R., Smith, J., Rose, P., Grabowski, K., 2015. Deep sediment-sourced methane contribution to shallow sediment organic carbon: Atwater Valley, Texas-Louisiana shelf, Gulf of Mexico. Energies 8, 1561-1583. doi:10.3390/en8031561

Conway, N., McDowell Capuzzo, J., 1991. Incorporation and utilization of bacterial lipids in the Solemya velum symbiosis. Mar. Biol. 108, 277-291. doi:10.1007/BF01344343

Cordes, E.E., Arthur, M.A., Shea, K., Arvidson, R.S., Fisher, C.R., 2005. Modeling the mutualistic interactions between tubeworms and microbial consortia. PLoS Biol. 3, e77. doi:10.1371/journal.pbio.0030077

Cowie, G.L., Hedges, J.I., 1994. Biochemical indicators of diagenetic alteration in natural organic matter mixtures. Nature 369, 304-307. 
Dalsgaard, J., St John, M., Kattner, G., Muller-Navarra, D., Hagen, W., 2003. Fatty acid trophic markers in the pelagic marine environment, in: Advances in Marine Biology. Elsevier, pp. 225-340.

Danovaro, R., Dell'Anno, A., Fabiano, M., 2001. Bioavailability of organic matter in the sediments of the Porcupine Abyssal Plain, northeastern Atlantic. Mar. Ecol. Prog. Ser. 220, 25-32. doi:10.3354/meps220025

Danovaro, R., Fabiano, M., Della Croce, N., 1993. Labile organic matter and microbial biomasses in deep-sea sediments (Eastern Mediterranean Sea). Deep Sea Res. Part I Oceanogr. Res. Pap. 40, 953-965. doi:10.1016/0967-0637(93)90083-F

Dauwe, B., Middelburg, J.J., 1998. Amino acids and hexosamines as indicators of organic matter degradation state in North Sea sediments. Limnol. Oceanogr. 43, 782-798.

Dauwe, B., Middelburg, J.J., Herman, P.M.J., Heip, C.H.R., 1999a. Linking diagenetic alteration of amino acids and bulk organic matter reactivity. Limnol. Oceanogr. 44, 1809-1814.

Dauwe, B., Middelburg, J.J., Van Rijswijk, P., Sinke, J., Herman, P.M.J., Heip, C.H.R., 1999b. Enzymatically hydrolyzable amino acids in North Sea sediments and their possible implication for sediment nutritional values. J. Mar. Res. 57, 109-134.

Decker, C., Olu, K., 2012. Habitat heterogeneity influences cold-seep macrofaunal communities within and among seeps along the Norwegian margin - Part 2: contribution of chemosynthesis and nutritional patterns: Nutritional patterns at Norwegian cold seeps. Mar. Ecol. 33, 231-245. doi:10.1111/j.1439-0485.2011.00486.x

Decker, C., Olu, K., Arnaud-Haond, S., Duperron, S., 2013. Physical proximity may promote lateral acquisition of bacterial symbionts in vesicomyid clams. PLoS ONE 8, e64830. doi:10.1371/journal.pone.0064830

Dell'Anno, A., Mei, M.L., Pusceddu, A., Danovaro, R., 2002. Assessing the trophic state and eutrophication of coastal marine systems: a new approach based on the biochemical composition of sediment organic matter. Mar. Pollut. Bull. 4, 611-622.

Dennielou, B., Droz, L., Jacq, C., Babonneau, N., Bonnel, C., Picot, M., Le Saout, M., Saout, J., Bez, M., Savoye, B., Olu, K., Rabouille, C., 2017. Morphology, structure, composition and build-up processes of the active channel-mouth lobe complex of the Congo deep-sea fan with inputs from remotely operated underwater vehicle (ROV) multibeam and video surveys. Deep Sea Research II, this volume.

Dettmer, K., Stevens, A., Fagerer, S., Kaspar, H., Oefner, P., 2012. Amino acid analysis in physiological samples by GC-MS with propyl chloroformate derivatization and iTRAQ-LC-MS/MS, in: Alterman, M.A., Hunziker, P. (Eds.), Amino Acid Analysis, Methods in Molecular Biology. Humana Press, pp. 165-181. doi:10.1007/978-1-61779-445-2_15

Dubois, M., Gilles, K.A., Hamilton, J.K., Rebers, P.A., Smith, F., 1956. Colorimetric method for determination of sugars and related substances. Anal. Chem. 28, 350-356. doi:10.1021/ac60111a017

Duperron, S., Sibuet, M., MacGregor, B.J., Kuypers, M.M.M., Fisher, C.R., Dubilier, N., 2007. Diversity, relative abundance and metabolic potential of bacterial endosymbionts in three Bathymodiolus mussel species from cold seeps in the Gulf of Mexico. Environ. Microbiol. 9, 1423-1438. doi:10.1111/j.1462-2920.2007.01259.x

Elvert, M., Boetius, A., Knittel, K., Jørgensen, B.B., 2003. Characterization of specific membrane fatty acids as chemotaxonomic markers for sulfate-reducing bacteria involved in anaerobic oxidation of methane. Geomicrobiol. J. 20, 403-419. 
Embley, R.W., Eittreim, S.L., McHugh, C.H., Normark, W.R., Rau, G.H., Hecker, B., DeBevoise, A.E., Greene, H.G., Ryan, W.B.F., Harrold, C., Baxter, C., 1990. Geological setting of chemosynthetic communities in the Monterey Fan Valley system. Deep Sea Res. Part I Oceanogr. Res. Pap. 37, 1651-1667. doi:10.1016/0198-0149(90)90069-8

Fiala-Médioni, A., Le Pennec, M., 1988. Structural adaptations in the gill of the japanese subduction zone bivalves (vesicomyidae) Calyptogena phaseoliformis and Calyptogena laubieri. Oceanol. Acta 11, 185-192.

Findlay, R.H., Trexler, M.B., Guckert, J.B., White, D.C., 1990. Laboratory study of disturbance in marine sediments: Response of a microbial community. Mar. Ecol. Prog. Ser. 62, 121-133.

Fischer, D., Sahling, H., Nöthen, K., Bohrmann, G., Zabel, M., Kasten, S., 2012. Interaction between hydrocarbon seepage, chemosynthetic communities, and bottom water redox at cold seeps of the Makran accretionary prism: insights from habitat-specific pore water sampling and modeling. Biogeosciences 9, 2013-2031. doi:10.5194/bg-9-2013-2012

Fry, B., Sherr, E.B., 1984. $\delta^{13} \mathrm{C}$ measurements as indicators of carbon flow in marine and freshwater ecosystems. Contrib. Mar. Sci. 27, 13-47.

Galéron, J., Menot, L., Renaud, N., Crassous, P., Khripounoff, A., Treignier, C., Sibuet, M., 2009. Spatial and temporal patterns of benthic macrofaunal communities on the deep continental margin in the Gulf of Guinea. Deep Sea Res. Part II Top. Stud. Oceanogr. 56, 2299-2312. doi:10.1016/j.dsr2.2009.04.011

Gao, F., Li, F., Tan, J., Yan, J., Sun, H., 2014. Bacterial community composition in the gut xontent and ambient sediment of sea cucumber Apostichopus japonicus revealed by 16S rRNA gene pyrosequencing. PLoS ONE June 26.

Gooday, A., Pond, D., Bowser, S., 2002. Ecology and nutrition of the large agglutinated foraminiferan Bathysiphon capillare in the bathyal NE Atlantic: distribution within the sediment profile and lipid biomarker composition. Mar. Ecol. Prog. Ser. 245, 69-82. doi:10.3354/meps245069

Grémare, A., Medernach, L., deBovée, F., Amouroux, J.M., Vétion, G., Albert, P., 2002. Relationships between sedimentary organics and benthic meiofauna on the continental shelf and the upper slope of the Gulf of Lions (NW Mediterranean). Mar. Ecol. Prog. Ser. 234, 85-94. doi:10.3354/meps234085

Grutters, M., van Raaphorst, W., Helder, W., 2001. Total hydrolysable amino acid mineralisation in sediments across the northeastern Atlantic continental slope (Goban Spur). Deep-Sea Res. Part I Oceanogr. Res. Pap. 48, 811-832. doi:10.1016/\$0967-0637(00)00075-3

Heezen, B.C., Menzies, R.J., Schneider, E.D., Ewing, W.M., Granelli, N.C.L., 1964. Congo submarine Canyon. AAPG bulletin 48, 1126-1149.

Hentschel, U., Felbeck, H., 1993. Nitrate respiration in the hydrothermal vent tubeworm Riftia pachyptila. Nature 366, 338-340. doi:10.1038/366338a0

Hsu, P.-H., Hatcher, P.G., 2005. New evidence for covalent coupling of peptides to humic acids based on 2D NMR spectroscopy: A means for preservation. Geochim. Cosmochim. Acta 69, 45214533. doi:10.1016/j.gca.2005.05.005

Hudson, I.R., Pond, D.W., Billett, D.S.M., Tyler, P.A., Lampitt, R.S., Wolff, G.A., 2004. Temporal variations in fatty acid composition of deep-sea holothurians: evidence of bentho-pelagic coupling. Mar. Ecol. Prog. Ser. 281, 109-120. doi:10.3354/meps281109

Iken, K., Brey, T., Wand, U., Voigt, J., Junghans, P., 2001. Food web structure of the benthic community at the Porcupine Abyssal Plain (NE Atlantic): a stable isotope analysis. Prog. Oceanogr. 50, 383-405. doi:10.1016/S0079-6611(01)00062-3 
Isla, E., Rossi, S., Palanques, A., Gili, J.M., Gerdes, D., Arntz, W., 2006. Biochemical composition of marine sediment from the eastern Weddell Sea (Antarctica): High nutritive value in a high benthic-biomass environment. J. Mar. Syst. 60, 255-267. doi:10.1016/j.jmarsys.2006.01.006

Jennerjahn, T.C., Ittekkot, V., 1997. Organic matter in sediments in the mangrove areas and adjacent continental margins of Brazil: I. Amino acids and hexosamines. Oceanol. Acta 20, 359-369.

Kharlamenko, V.I., Stepanov, V.G., Borisovets, E.E., Kiyashko, S.I., Svetashev, V.I., 2015. The fatty acid composition and nutrition of deep-sea holothurians from the Sea of Okhotsk. Russ. J. Mar. Biol. 41, 448-455. doi:10.1134/S106307401506005X

Khripounoff, A., Caprais, J.C., Decker, C., Essirard, M., Le Bruchec, J., Noel, P., Olu, K., 2015. Variability in gas and solute fluxes through deep-sea chemosynthetic ecosystems inhabited by vesicomyid bivalves in the Gulf of Guinea. Deep Sea Res. Part I Oceanogr. Res. Pap. 95, 122130. doi:10.1016/j.dsr.2014.10.013

Kiriakoulakis, K., Stutt, E., Rowland, S.J., Vangriesheim, A., Lampitt, R.S., Wolff, G.A., 2001. Controls on the organic chemical composition of settling particles in the Northeast Atlantic Ocean. Prog. Oceanogr. 50, 65-87. doi:10.1016/S0079-6611(01)00048-9

Knicker, H., 2004. Stabilization of N-compounds in soil and organic-matter-rich sediments-what is the difference? Mar. Chem. 92, 167-195. doi:10.1016/j.marchem.2004.06.025

Krylova, E.M., Cosel, R.V., 2011. A new genus of large Vesicomyidae (Mollusca, Bivalvia, Vesicomyidae, Pliocardiinae) from the Congo margin, with the first record of the subfamily Pliocardiinae in the Bay of Biscay (northeastern Atlantic). Zoosystema 33, 83-99. doi:10.5252/z2011n1a4

Krylova, E.M., Sahling, H., Janssen, R., 2010. Abyssogena: a new genus of the family Vesicomyidae (Bivalvia) from deep-water vents and seeps. J. Molluscan Stud. 76, 107-132. doi:10.1093/mollus/eyp052

Kuwahara, H., Yoshida, T., Takaki, Y., Shimamura, S., Nishi, S., Harada, M., Matsuyama, K., Takishita, K., Kawato, M., Uematsu, K., Fujiwara, Y., Sato, T., Kato, C., Kitagawa, M., Kato, I., Maruyama, T., 2007. Reduced genome of the thioautotrophic intracellular symbiont in a deep-sea clam, Calyptogena okutanii. Curr. Biol. 17, 881-886. doi:10.1016/j.cub.2007.04.039

Lampitt, R.S., 1985. Evidence for the seasonal deposition of detritus to the deep-sea floor and its subsequent resuspension. Deep Sea Res. Part I Oceanogr. Res. Pap. 32, 885-897. doi:10.1016/0198-0149(85)90034-2

Lee, C., Wakeham, S., Arnosti, C., 2004. Particulate organic matter in the sea: the composition conundrum. AMBIO J. Hum. Environ. 33, 565-575. doi:10.1579/0044-7447-33.8.565

Lee, R.W., Robinson, J.J., Cavanaugh, C.M., 1999. Pathways of inorganic nitrogen assimilation in chemoautotrophic bacteria-marine invertebrate symbioses: expression of host and symbiont glutamine synthetase. J. Exp. Biol. 202 (Pt 3), 289-300.

Leonard, A.E., Pereira, S.L., Sprecher, H., Huang, Y.-S., 2004. Elongation of long-chain fatty acids. Prog. Lipid Res. 43, 36-54. doi:10.1016/S0163-7827(03)00040-7

Levin, L.A., 2005. Ecology of cold seep sediments: Interactions of fauna with flow, chemistry and microbes, in: Oceanography and Marine Biology - an Annual Review, Vol. 43, Oceanography and Marine Biology. CRC Press-Taylor and Francis Group, Boca Raton, pp. 1-46.

Levin, L.A., Mendoza, G.F., 2007. Community structure and nutrition of deep methane-seep macrobenthos from the North Pacific (Aleutian) Margin and the Gulf of Mexico (Florida Escarpment). Mar. Ecol. 28, 131-151. doi:10.1111/j.1439-0485.2006.00131.x 
Levin, L.A., Michener, R.H., 2002. Isotopic evidence for chemosynthesis-based nutrition of macrobenthos: The lightness of being at Pacific methane seeps. Limnol. Oceanogr. 47, 13361345. doi:10.4319/lo.2002.47.5.1336

Lomstein, B.A., Jørgensen, B.B., Schubert, C.J., Niggemann, J., 2006. Amino acid biogeo- and stereochemistry in coastal Chilean sediments. Geochim. Cosmochim. Acta 70, 2970-2989.

MacAvoy, S.E., Macko, S.A., Carney, R.S., 2003. Links between chemosynthetic production and mobile predators on the Louisiana continental slope: stable carbon isotopes of specific fatty acids. Chem. Geol. 201, 229-237. doi:10.1016/S0009-2541(03)00204-3

Macko, S.A., Fogel, M.L., Hare, P.E., Hoering, T.C., 1987. Isotopic fractionation of nitrogen and carbon in the synthesis of amino acids by microorganisms. Chem. Geol. Isot. Geosci. Sect. 65, 79-92. doi:10.1016/0168-9622(87)90064-9

Mayer, L., Benninger, L., Bock, M., DeMaster, D., Roberts, Q., Martens, C., 2002. Mineral associations and nutritional quality of organic matter in shelf and upper slope sediments off Cape Hatteras, USA: a case of unusually high loadings. Deep Sea Res. Part II Top. Stud. Oceanogr. 49, 4587-4597.

Mayer, L.A., Shor, A.N., Hughes Clarke, J., Piper, D.J.W., 1988. Dense biological communities at 3850 $\mathrm{m}$ on the Laurentian Fan and their relationship to the deposits of the 1929 Grand Banks earthquake. Deep Sea Res. Part I Oceanogr. Res. Pap. 35, 1235-1246. doi:10.1016/01980149(88)90079-9

Mayer, L.M., Schick, L.L., Sawyer, T., Plante, C.J., Jumars, P.A., Self, R.L., 1995. Bioavailable amino acids in sediments: a biomimetic, kinetics-based approach. Limnol. Oceanogr. 40, 511-520.

McCaffrey, M.A., Farrington, J.W., Repeta, D.J., 1989. Geochemical implications of the lipid composition of Thioploca spp. from the Peru upwelling region $-15^{\circ} \mathrm{S}$. Org. Geochem. 14, 6168. doi:10.1016/0146-6380(89)90019-3

Meade, R.H., 1996. River-sediment inputs to major deltas, in: Milliman, J.D., Haq, B.U. (Eds.), SeaLevel Rise and Coastal Subsidence: Causes, Consequences and Strategies. Kluwer Academic Publishers, pp. 63-85.

Michener, R.H., Kaufman, L., 2007. Stable isotope ratios as tracers in marine food webs: an update, in: Michener, R., Lajtha, K. (Eds.), Stable isotopes in ecology and environmental science. Blackwell Publishing Ltd, Oxford, UK, pp. 238-282.

Monroig, Ó., Tocher, D., Navarro, J., 2013. Biosynthesis of polyunsaturated fatty acids in marine invertebrates: recent advances in molecular mechanisms. Mar. Drugs 11, 3998-4018. doi:10.3390/md11103998

Neira, C., Sellanes, J., Soto, A., Gutiérrez, D., Gallardo, V.A., 2001. Meiofauna and sedimentary organic matter off Central Chile: response to changes caused by the 1997-1998 El Niño. Oceanol. Acta 24.

Newton, I.L.G., Woyke, T., Auchtung, T.A., Dilly, G.F., Dutton, R.J., Fisher, M.C., Fontanez, K.M., Lau, E., Stewart, F.J., Richardson, P.M., Barry, K.W., Saunders, E., Detter, J.C., Wu, D., Eisen, J.A., Cavanaugh, C.M., 2007. The Calyptogena magnifica chemoautotrophic symbiont genome. Science 315, 998-1000. doi:10.1126/science.1138438

Nichols, D.S., 2003. Prokaryotes and the input of polyunsaturated fatty acids to the marine food web. FEMS Microbiol. Lett. 219, 1-7.

Olu, K., 2011. WACS cruise,Pourquoi pas ? R/V. doi:10.17600/11030010

Olu, K., Caprais, J.C., Galeron, J., Causse, R., von Cosel, R., Budzinski, H., Le Menach, K., Le Roux, C., Levache, D., Khripounoff, A., Sibuet, M., 2009. Influence of seep emission on the non- 
symbiont-bearing fauna and vagrant species at an active giant pockmark in the Gulf of Guinea (Congo-Angola margin). Deep-Sea Res. Part II-Top. Stud. Oceanogr. 56, 2380-2393. doi:10.1016/j.dsr2.2009.04.017

Olu, K., Decker, C., Morineaux, M., Ain Baziz, M., Menot, L., Caprais, J.-C., Cathalot, C., Pastor, L., Kryvola, E, Rabouille, C, submitted, this volume. Variability of macrofaunal community structure in reducing sediments of the Congo deep-sea fan, hypotheses about their dynamics and similarities with cold-seep counterparts. Deep-Sea Res. II submitted, this volume.

Olu-Le Roy, K., Caprais, J.-C., Fifis, A., Fabri, M.-C., Galéron, J., Budzinsky, H., Le Ménach, K., Khripounoff, A., Ondréas, H., Sibuet, M., 2007. Cold-seep assemblages on a giant pockmark off West Africa: spatial patterns and environmental control. Mar. Ecol. 28, 115-130. doi:10.1111/j.1439-0485.2006.00145.x

Pastor, L., Toffin, L., Caprais, J.-C., Bessette, S., Lesongeur, F., Brandily, C., Godfroy, A., Olu, K., submitted, 2017. Evidence for AOM in symbiotic bivalves habitats from the Congo deep-sea fan lobes. Deep-Sea Res. II, this volume. http://dx.doi.org/10.1016/j.dsr2.2017.03.011

Patnayak, S., Sree, A., 2005. Screening of bacterial associates of marine sponges for single cell oil and PUFA. Lett. Appl. Microbiol. 40, 358-363. doi:10.1111/j.1472-765X.2005.01671.x

Paull, C.K., Schlining, B., Ussler, W., Lundste, E., Barry, J.P., Caress, D.W., Johnson, J.E., McGann, M., 2010. Submarine mass transport within monterey canyon: benthic disturbance controls on the distribution of chemosynthetic biological communities, in: Mosher, D.C., Shipp, R.C., Moscardelli, L., Chaytor, J.D., Baxter, C.D.P., Lee, H.J., Urgeles, R. (Eds.), Submarine mass movements and their consequences. Springer Netherlands, Dordrecht, pp. 229-246.

Pfannkuche, O., Thiel, H., 1987. Meiobenthic stocks and benthic activity on the NE-Svalbard shelf and in the Nansen Basin. Polar Biol. 7, 253-266. doi:10.1007/BF00443943

Philben, M., Benner, R., 2013. Reactivity of hydroxyproline-rich glycoproteins and their potential as biochemical tracers of plant-derived nitrogen. Org. Geochem. 57, 11-22. doi:10.1016/j.orggeochem.2013.01.003

Philben, M., Ziegler, S.E., Edwards, K.A., Kahler, R., Benner, R., 2016. Soil organic nitrogen cycling increases with temperature and precipitation along a boreal forest latitudinal transect. Biogeochemistry 127, 397-410. doi:10.1007/s10533-016-0187-7

Pop Ristova, P., Wenzhöfer, F., Ramette, A., Zabel, M., Fischer, D., Kasten, S., Boetius, A., 2012. Bacterial diversity and biogeochemistry of different chemosynthetic habitats of the REGAB cold seep (West African margin, 3160 m water depth). Biogeosciences 9, 5031-5048. doi:10.5194/bg-9-5031-2012

Pozzato, L., Cathalot, C., Berrached, C., Toussaint, F., Stetten, E., Caprais, J.C., Pastor, L., Olu, K., Rabouille, C. Early diagenesis in the Congo deep-sea fan sediments dominated by massive terrigenous deposits: Part I - Oxygen consumption and organic carbon mineralization using a micro-electrode approach. Deep Sea Res. Part II Top. Stud. Oceanogr. submitted, this volume.

Pruski, A.M., Buscail, R., Bourgeois, S., Vétion, G., Coston-Guarini, J., Rabouille, C., 2015. Biogeochemistry of fatty acids in a river-dominated Mediterranean ecosystem (Rhône River prodelta, Gulf of Lions, France): Origins and diagenesis. Org. Geochem. 83-84, 227-240. doi:10.1016/j.orggeochem.2015.04.002

Pusceddu, A., Bianchelli, S., Canals, M., Sanchez-Vidal, A., Durrieu De Madron, X., Heussner, S., Lykousis, V., de Stigter, H., Trincardi, F., Danovaro, R., 2010. Organic matter in sediments of canyons and open slopes of the Portuguese, Catalan, Southern Adriatic and Cretan Sea margins. Deep Sea Res. Part I Oceanogr. Res. Pap. 57, 441-457. doi:10.1016/j.dsr.2009.11.008 
Rabouille, C., 2011. Congolobe cruise,Pourquoi pas ? R/V. doi:10.17600/11030170

Rabouille, C., Caprais, J.-C., Lansard, B., Crassous, P., Dedieu, K., Reyss, J.L., Khripounoff, A., 2009. Organic matter budget in the Southeast Atlantic continental margin close to the Congo Canyon: In situ measurements of sediment oxygen consumption. Deep Sea Res. Part II Top. Stud. Oceanogr. 56, 2223-2238. doi:10.1016/j.dsr2.2009.04.005

Rabouille, C., Olu, K., Baudin, F., Khripounoff, A., Dennielou, B., Arnaud-Haond, S., Babonneau, N., Bayle, C., Beckler, J., Bessette, S., Bombled, B., Bourgeois, S., Brandily, C., Caprais, J.C., Cathalot, C., Charlier, K., Corvaisier, R., Croguennec, C., Cruaud, P., Decker, C., Droz, L., Gayet, N., Godfroy, A., Hourdez, S., Le Bruchec, J., Le Saout, J., Lesaout, M., Lesongeur, F., Martinez, P., Mejanelle, L., Michalopoulos, P., Mouchel, O., Noel, P., Pastor, L., Picot, M., Pignet, P., Pozzato, L., Pruski, A.M., Rabiller, M., Raimonet, M., Ragueneau, O., Reyss, J.L., Rodier, P., Ruesch, B., Ruffine, L., Savignac, F., Senyarich, C., Schnyder, J., Sen, A., Stetten, E., Sun, M.Y., Taillefert, M., Teixeira, S., Tisnerat-Laborde, N., Toffin, L., Tourolle, J., Toussaint, F., Vétion, G., Jouanneau, J.M., Bez, M., this volume. The Congolobe project, a multidisciplinary study of Congo deep-sea fan lobe complex: Overview of methods, strategies, observations and sampling. Deep Sea Res. Part II Top. Stud. Oceanogr. doi:10.1016/j.dsr2.2016.05.006

Rossi, F., Lardicci, C., 2002. Role of the nutritive value of sediment in regulating population dynamics of the deposit-feeding polychaete Streblospio shrubsolii. Mar. Biol. 140, 1129-1138. doi:10.1007/s00227-001-0768-3

Ruby, E.G., Jannasch, H.W., Deuser, W.G., 1987. Fractionation of stable carbon isotopes during chemoautotrophic growth of sulfur-oxidizing bacteria. Appl. Environ. Microbiol. 53, 19401943.

Saito, H., 2007. Identification of novel n-4 series polyunsaturated fatty acids in a deep-sea clam, Calyptogena phaseoliformis. J. Chromatogr. A 1163, 247-259. doi:10.1016/j.chroma.2007.06.016

Salvo, F., Dufour, S.C., Hamoutene, D., Parrish, C.C., 2015. Lipid Classes and Fatty Acids in Ophryotrocha cyclops, a Dorvilleid from Newfoundland Aquaculture Sites. PLOS ONE 10, e0136772. doi:10.1371/journal.pone.0136772

Savoye, B., Babonneau, N., Dennielou, B., Bez, M., 2009. Geological overview of the Angola-Congo margin, the Congo deep-sea fan and its submarine valleys. Deep-Sea Res. Part II-Top. Stud. Oceanogr. 56, 2169-2182. doi:10.1016/j.dsr2.2009.04.001

Schnyder, J., Stetten, E., Baudin, F., Pruski, A.M., Martinez, P., submitted, this volume. Fresh terrestrial organic matter delivered to terminal Congo deep sea fan as revealed by palynofacies. Deep-Sea Res. II this volume.

Sen, A., Arnaubec, A., Decker, C., Droz, L., Dennielou, B., Rabouille, C, Olu, K, submitted, this volume. Distribution of chemosynthesis-based and detrital-based megafauna and habitats in the Congo Deep-Sea fan. Deep-Sea Res. II this volume.

Sibuet, M., Monniot, C., Desbruyères, D., Dinet, A., Khripounoff, A., Rowe, G., Ségonzac, M., 1984. Benthic populations and trophic characteristics in the Demerare abyssal basin (AtlanticOcean). Oceanol. Acta 7, 345-358.

Sibuet, M., Vangriesheim, A., 2009. Deep-sea environment and biodiversity of the West African Equatorial margin. Deep-Sea Res. Part II-Top. Stud. Oceanogr. 56, 2156-2168. doi:10.1016/j.dsr2.2009.04.015

Soltwedel, T., 1997. Meiobenthos distribution pattern in the tropical East Atlantic: indication for fractionated sedimentation of organic matter to the sea floor? Mar. Biol. 129, 747-756. 
Spencer, R.G.M., Hernes, P.J., Aufdenkampe, A.K., Baker, A., Gulliver, P., Stubbins, A., Aiken, G.R., Dyda, R.Y., Butler, K.D., Mwamba, V.L., Mangangu, A.M., Wabakanghanzi, J.N., Six, J., 2012. An initial investigation into the organic matter biogeochemistry of the Congo River. Geochim. Cosmochim. Acta 84, 614-627. doi:10.1016/j.gca.2012.01.013

Stetten, E., 2015. Origine, distribution et réactivité de la matière organique associée aux lobes terminaux du système turbiditique du Congo. Thèse Université Pierre et Marie Curie - Paris VI, Paris, France. 238 pages.

Stetten, E., Baudin, F., Reyss, J.-L., Martinez, P., Charlier, K., Schnyder, J., Rabouille, C., Dennielou, B., Coston-Guarini, J., Pruski, A.M., 2015. Organic matter characterization and distribution in sediments of the terminal lobes of the Congo deep-sea fan: Evidence for the direct influence of the Congo River. Mar. Geol. 369, 182-195. doi:10.1016/j.margeo.2015.08.020

Sun, M.-Y., Aller, R.C., Lee, C., Wakeham, S.G., 1999. Enhanced degradation of algal lipids by benthic macrofaunal activity: Effect of Yoldia limatula. J. Mar. Res. 57, 775-804. doi:10.1357/002224099321560573

Taillefert, M., Beckler, J. S., Cathalot, C., Michalopoulos, P., Corvaisier, R., Kiriazis, N., Caprais, J. C., Pastor, L., Rabouille, C. Early diagenesis in the sediments of the Congo deep-sea fan dominated by massive terrigenous deposits: Part II - Iron-sulfur coupling. Deep Sea Res. Part II Top. Stud. Oceanogr. this volume.

Talbot, H.M., Handley, L., Spencer-Jones, C.L., Dinga, B.J., Schefuß, E., Mann, P.J., Poulsen, J.R., Spencer, R.G.M., Wabakanghanzi, J.N., Wagner, T., 2014. Variability in aerobic methane oxidation over the past 1.2 Myrs recorded in microbial biomarker signatures from Congo fan sediments. Geochim. Cosmochim. Acta 133, 387-401. doi:10.1016/j.gca.2014.02.035

Teixeira, S., Olu, K., Decker, C., Cunha, R.L., Fuchs, S., Hourdez, S., Serrão, E.A., Arnaud-Haond, S., 2013. High connectivity across the fragmented chemosynthetic ecosystems of the deep Atlantic Equatorial Belt: efficient dispersal mechanisms or questionable endemism? Mol. Ecol. 22, 4663-4680. doi:10.1111/mec.12419

Tenore, K., Hanson, R., Mcclain, J., Maccubbin, A., Hodson, R., 1984. Changes in composition and nutritional value to a benthic deposit feeder. Bull. Mar. Sci. 35, 299-311.

Thurber, A.R., Kröger, K., Neira, C., Wiklund, H., Levin, L.A., 2010. Stable isotope signatures and methane use by New Zealand cold seep benthos. Mar. Geol. 272, 260-269. doi:10.1016/j.margeo.2009.06.001

Thurber, A.R., Levin, L.A., Orphan, V.J., Marlow, J.J., 2012. Archaea in metazoan diets: implications for food webs and biogeochemical cycling. ISME J. 6, 1602-1612. doi:10.1038/ismej.2012.16

Thurber, A.R., Levin, L.A., Rowden, A.A., Sommer, S., Linke, P., Kröger, K., 2013. Microbes, macrofauna, and methane: A novel seep community fuelled by aerobic methanotrophy. Limnol. Oceanogr. 58, 1640-1656. doi:10.4319/lo.2013.58.5.1640

Treignier, C., Derenne, S., Saliot, A., 2006. Terrestrial and marine $n$-alcohol inputs and degradation processes relating to a sudden turbidity current in the Zaire canyon. Org. Geochem. 37, 1170-1184. doi:10.1016/j.orggeochem.2006.03.010

Tselepides, A., Polychronaki, T., Marrale, D., Akoumianaki, I., Dell'Anno, A., Pusceddu, A., Roberto Danovaro, 2000. Organic matter composition of the continental shelf and bathyal sediments of the Cretan Sea (NE Mediterranean). Prog. Oceanogr. 46, 311-344. doi:10.1016/S00796611(00)00024-0 
Unger, D., Gaye-Haake, B., Neumann, K., Gebhardt, A.C., Ittekkot, V., 2005. Biogeochemistry of suspended and sedimentary material in the $\mathrm{Ob}$ and Yenisei rivers and Kara Sea: amino acids and amino sugars. Cont. Shelf Res. 25, 437-460.

Van Gaever, S., Galéron, J., Sibuet, M., Vanreusel, A., 2009. Deep-sea habitat heterogeneity influence on meiofaunal communities in the Gulf of Guinea. Deep Sea Res. Part II Top. Stud. Oceanogr. 56, 2259-2269. doi:10.1016/j.dsr2.2009.04.008

Whelan, J.K., 1977. Amino acids in a surface sediment core of the Atlantic abyssal plain. Geochim. Cosmochim. Acta 41, 803-810. doi:10.1016/0016-7037(77)90050-3

Wilmot, D.B., Vetter, R.D., 1992. Oxygen- and nitrogen-dependent sulfur metabolism in the thiotrophic clam Solemya reidi. Biol. Bull. 182, 444-453. doi:10.2307/1542264

Zhao, Y., Shan, B., Tang, W., Zhang, H., Rong, N., Ding, Y., 2016. Distributions, early diagenesis, and spatial characteristics of amino acids in sediments of multi-polluted rivers: A case study in the Haihe River Basin, China. Int. J. Environ. Res. Public. Health 13: 234.

doi:10.3390/ijerph13020234 


\section{Figure legend}

Fig. 1: General bathymetric maps showing (A) the Congo deep-sea fan with its active channel, and (B) the terminal part of the Congo deep-sea fan with location of the study sites (WACS and Congolobe campaigns): Sites $A, F, C$ and $B$ are located on the recent lobe complex, Site $E$ is located on the abandoned lobe complex. The box in Fig. $1 \mathrm{~A}$ indicates the study area, whereas boxes on Fig. $1 \mathrm{~B}$ delineate the sampling area for Site A (Fig. 2), Site B, Site F (Fig. 3), Site C (Fig. 4) and Site E.

Fig. 2: High-resolution bathymetric map of Site $A$ at the entrance of the lobe complex $(A)$ showing location of the two habitats sampled (the boxes correspond to the area enlarged in Fig. 2B and C). Close-up views of the bare sediment habitat on the North levee (B) and the vesicomyid habitat at the South of the channel $(C)$ with location of operations, and sampling markers. Note simplified labels (excluding station name and replacing WACS by W) for clarity of the figures.

Fig. 3: High-resolution bathymetric map (A) and close-up view (B) of Site F located in the middle of the lobe complex with location of operations, and sampling markers. The box on Fig. 3A corresponds to the area enlarged in Fig. 3B. Note simplified labels (excluding station name) for clarity of the figures.

Fig. 4: High-resolution bathymetric map of Site $\mathrm{C}$ located at the most distal reach of the active channel (A) with location of operations, and sampling markers (the box corresponds to the area enlarged in Fig. 4B). Close-up view (B) showing the precise location of sediment coring and animal sampling. Note simplified labels (excluding station name and replacing WACS by W) for clarity of the figures.

Fig. 5. Representative views of habitats and megafauna from the distal lobe complex of the Congo deep-sea fan (4750-4950 m depth) and REGAB pockmark (3200 m depth). The abandoned Site E only received hemipelagic inputs and is inhabited by classical abyssal fauna such as suspension-feeding poriferans (A). Sparse and dense chemosynthetic habitats are found along the active channel where turbidity currents enriched the seafloor with OM rich-deposits: (B) a small patch of vesicomyid clams with epicommensal actinarians (Site B), (C) bare sediments with giant foraminifers (Bathysiphon sp.) and a small holothurian (Site B), (D) a transparent holothurian on a dense cluster of vesicomyids (Site A); Ampharetidae polychaetes are also visible among vesicomyid clams, (E) sampling of sediments with a push core; the boundary between the clam habitat and the surrounding non reduced sediments is clearly visible (Site A). Similar assemblages were previously observed at the REGAB pockmark located $8 \mathrm{~km}$ North to the Congo channel: (F) aggregate of the vesicomyid C. regab with holothurians (Chiridota sp.), shrimps (Alvinocaris muricola) and galatheids (Olu et al. 2009). Photo credit: IFREMER. 
Fig. 6: Biopolymeric carbon (BPC) in surface sediments from the distal lobe complex of the Congo deep-sea fan and sediments from the African continent (Malebo Pool on the Congo River). Left axis: contribution of proteins (TAA-C), carbohydrates (CARB-C) and lipids (LIP-C) to the total organic carbon; right axis: proteins to carbohydrates ratio. $\mathrm{PS}=$ permanently submerged, $\mathrm{BS}=$ bank sediment, $F P=$ floodplain.

Fig. 7. Amino acid composition of surface sediments from the Malebo Pool (A) and the distal lobe of the Congo deep-sea fan (B). PS= permanently submerged, $B S=$ bank sediment, $F P=$ floodplain, $\mathrm{Gly}=$ glycine, Asx= aspartic acid + asparagine, Ala= alanine, Glx= glutamic acid + glutamine, Thr= threonine, Ser= serine, $\mathrm{Val}=$ valine, Leu= leucine, Pro= proline, Lys=lysine, lleu= isoleucine, Phe= phenylalanine, His= histidine, Hpro= hydroxyproline, BALA $=\beta$-glutamic acid, GABA, $\gamma$-aminobutyric acid, bacterial= ornithine, $\beta$-glutamic acid, diaminopimelic acid, and $\alpha$-aminobutyric acid. Tyrosine and methionine were present in trace amounts.

Fig. 8. Dual isotope signatures of macrofauna from the distal lobe complex of the Congo deep-sea fan. (A) Macrofauna collected on background sediments and within the vesicomyid habitats. Each point represents a distinct individual. Known symbiont-bearing clams, heterotrophic infauna and mobile taxa are indicated with separate symbols. Average values for sediments from the recent lobe (Sites A, F, C and B) are also provided (see Table 1). Feeding strategies are indicated in italic. Two food webs are discernible, one based on detritic OM, the other one linked to chemosynthetic production. (B) Plot summarizing mean $( \pm 1 \mathrm{SD}) \delta^{13} \mathrm{C}$ and $\delta^{15} \mathrm{~N}$ values for vesicomyids from the recent lobe complex and from the pockmark REGAB. Diamonds $=C$. regab, circles $=A$. southwardae, squares $=L$. chuni, open symbols $=$ gills and plain symbols $=$ mantles. The colour of the symbols indicate the collection site. A. southwardae is not present on Site $C$ and $L$. chuni is not present in the recent lobe complex. Within the REGAB pockmark, W5 and W3 sampling sites are located about 400 $\mathrm{m}$ apart, in the centre and in the SW part of the pockmark, respectively. Hypotheses explaining the different isotopic signatures are given in italic.

Fig. 9. Two-dimensional non-metric multidimensional scaling (MDS) ordination plot comparing fatty acid profiles of macrofauna from the distal lobe complex of the Congo deep-sea fan. Data points that are closer together in the two-dimensional space have more similar fatty acid profiles than points that are further apart. The 2D stress value (0.05) indicates confidence in the placement of samples relative to each other. Lines encircled the data points showing 60,70 or $90 \%$ similarities in fatty acid profile pattern (similarity levels derive from hierarchical clustering). The percentage of similarity and the three main fatty acids contributing to the similarity within these groups (SIMPER analysis) are indicated next to the clusters. The percentages of similarity between poriferans and amphipods, and 
between vesicomyid gills and foot are also provided. LC-MUFAs= long chain monounsaturated fatty acids containing 20 carbons or more.

Fig. 10: Fatty acid composition of two holothurians from the distal lobe complex of the Congo deepsea fan and their surrounding sediments. (A) and (B) Holothurians from Site B, and (C) surficial sediment $(0-0.5 \mathrm{~cm})$ from Site B (CoL-B-MTB12 C1).

Table 1: Compilation of the main geochemical and biochemical characteristics of background sediments from the distal lobe complex of the Congo deep-sea fan.

\begin{tabular}{|c|c|c|c|c|c|c|c|c|c|c|c|c|c|}
\hline Site & $\begin{array}{l}\text { Core } \\
\text { ID }\end{array}$ & $\begin{array}{l}\text { OC } \\
\%^{1}\end{array}$ & $\underset{2}{\mathrm{~N}} \%$ & $\begin{array}{l}\text { C:N } \\
\text { molar } \\
1\end{array}$ & $\delta^{13} C^{1}$ & $\delta_{1}^{15} \mathrm{~N}$ & $\begin{array}{c}\text { THA } \\
\text { A } \\
\text { mg.g } \\
\text { DW }^{2}\end{array}$ & $\begin{array}{c}\text { CAR } \\
\text { B } \\
\text { mg.g } \\
\text { DW }^{2}\end{array}$ & $\begin{array}{c}\text { Lipi } \\
\text { ds } \\
\text { mg. } \\
\text { g }^{-1} \\
\text { DW } \\
2\end{array}$ & $\begin{array}{c}\text { BPC } \\
\mathrm{mgC} \\
\cdot \mathrm{g}^{-1} \\
\mathrm{DW} \\
2\end{array}$ & $\begin{array}{l}\% \mathrm{~T}_{\mathrm{A}} \\
{ }_{\mathrm{A}} \mathbf{N}^{2}\end{array}$ & $\mathrm{DI}^{2}$ & $\mathrm{RI}^{2}$ \\
\hline \multirow{5}{*}{ A } & ColA & & & & - & & & \multicolumn{4}{|c|}{ Cr } & - & \\
\hline & - & 3.19 & 0.29 & 17. & 26.5 & 5.48 & 12.7 & 8.18 & 1.01 & 9.46 & 64.9 & 0.13 & 1.16 \\
\hline & MTB & \pm & \pm & $3 \pm$ & $7 \pm$ & \pm & $9 \pm$ & \pm & \pm & \pm & \pm & \pm & \pm \\
\hline & 03 & 0.32 & 0.04 & 1.1 & 0.21 & 0.45 & 1.15 & 0.83 & 0.19 & 0.44 & 14.6 & 0.27 & 0.47 \\
\hline & $\begin{array}{l}\text { ColF- } \\
\text { MTB }\end{array}$ & $\begin{array}{c}3.26 \\
\pm\end{array}$ & $\begin{array}{c}0.31 \\
\pm\end{array}$ & $\begin{array}{l}16 \\
6 \pm\end{array}$ & $\begin{array}{c}26.1 \\
6 \pm\end{array}$ & $\begin{array}{c}5.32 \\
\pm\end{array}$ & $\begin{array}{c}10.4 \\
6 \pm\end{array}$ & $\begin{array}{c}9.83 \\
\pm\end{array}$ & $\begin{array}{c}1.11 \\
\pm\end{array}$ & $\begin{array}{c}9.13 \\
\pm\end{array}$ & 47.4 & $\begin{array}{c}0.18 \\
\pm\end{array}$ & $\begin{array}{c}0.93 \\
\pm\end{array}$ \\
\hline$F$ & 05 & 0.42 & 0.02 & 1.3 & 0.45 & 0.20 & 0.64 & 0.56 & 0.05 & 0.26 & \pm 5.0 & 0.22 & 0.24 \\
\hline & $\begin{array}{l}\text { ColC- } \\
\text { MTB }\end{array}$ & $\begin{array}{c}3.94 \\
\pm\end{array}$ & $\begin{array}{c}0.35 \\
\pm\end{array}$ & $\begin{array}{l}15 \\
7 \pm\end{array}$ & $\begin{array}{c}26.8 \\
6 \pm\end{array}$ & $\begin{array}{c}5.32 \\
\pm\end{array}$ & $\begin{array}{c}12.9 \\
8 \pm\end{array}$ & $\begin{array}{c}8.42 \\
\pm\end{array}$ & $\begin{array}{c}1.08 \\
\pm\end{array}$ & $\begin{array}{c}9.73 \\
\pm\end{array}$ & $\begin{array}{c}51.2 \\
\pm\end{array}$ & $\begin{array}{c}0.14 \\
\pm\end{array}$ & $\begin{array}{c}1.38 \\
\pm\end{array}$ \\
\hline C & 11 & 0.36 & 0.02 & 0.7 & $\begin{array}{c}0.16 \\
-\end{array}$ & 0.31 & 1.43 & 0.50 & 0.16 & 0.84 & 3.7 & $\begin{array}{c}0.32 \\
-\end{array}$ & 0.31 \\
\hline & $\begin{array}{l}\text { ColB- } \\
\text { MTB }\end{array}$ & $\begin{array}{c}3.20 \\
\pm\end{array}$ & $\begin{array}{c}0.24 \\
\pm\end{array}$ & $\begin{array}{l}16 \\
4 \pm\end{array}$ & $\begin{array}{c}26.1 \\
0 \pm\end{array}$ & $\begin{array}{c}5.33 \\
\pm\end{array}$ & $\begin{array}{c}11.0 \\
1 \pm\end{array}$ & $\begin{array}{c}7.43 \\
\pm\end{array}$ & $\begin{array}{c}0.86 \\
\pm\end{array}$ & $\begin{array}{c}8.34 \\
\pm\end{array}$ & $\begin{array}{c}66.5 \\
\pm\end{array}$ & $\begin{array}{c}0.10 \\
\pm\end{array}$ & $\begin{array}{c}1.09 \\
\pm\end{array}$ \\
\hline B & 12 & 0.39 & 0.07 & 1.2 & $\begin{array}{c}0.37 \\
-\end{array}$ & 0.38 & 1.38 & 1.42 & 0.09 & 1.13 & 20.9 & $\begin{array}{c}0.28 \\
-\end{array}$ & 0.33 \\
\hline & $\begin{array}{l}\text { ColE- } \\
\text { MTB }\end{array}$ & $\begin{array}{c}1.85 \\
\pm\end{array}$ & $\begin{array}{c}0.19 \\
\pm\end{array}$ & $\begin{array}{l}13 . \\
2 \pm\end{array}$ & $\begin{array}{c}24.2 \\
1 \pm\end{array}$ & $\begin{array}{c}7.14 \\
\pm\end{array}$ & $\begin{array}{c}5.29 \\
\pm\end{array}$ & $\begin{array}{c}5.86 \\
\pm\end{array}$ & $\begin{array}{c}0.45 \\
\pm\end{array}$ & $\begin{array}{c}4.88 \\
\pm\end{array}$ & $\begin{array}{c}39.4 \\
\pm\end{array}$ & $\begin{array}{c}0.65 \\
\pm\end{array}$ & $\begin{array}{c}0.33 \\
\pm\end{array}$ \\
\hline $\mathrm{E}$ & 14 & 0.69 & 0.04 & 3.4 & 1.40 & 0.75 & 1.46 & 0.78 & 0.23 & 0.67 & 4.6 & 0.57 & 0.31 \\
\hline $\begin{array}{c}\text { Male } \\
\text { bo } \\
\text { pool }^{3}\end{array}$ & PS/F & $\begin{array}{c}1.13 \\
\pm\end{array}$ & $\begin{array}{c}0.15 \\
\pm\end{array}$ & $\begin{array}{l}15 \\
8 \pm\end{array}$ & & & $\begin{array}{c}18.5 \\
2 \pm\end{array}$ & $\begin{array}{c}12.8 \\
0 \pm\end{array}$ & $\begin{array}{c}1.69 \\
\pm\end{array}$ & $\begin{array}{c}5.76 \\
\pm\end{array}$ & $\begin{array}{c}72.1 \\
\pm\end{array}$ & $\begin{array}{c}0.47 \\
\pm\end{array}$ & $\begin{array}{c}1.23 \\
\pm\end{array}$ \\
\hline $\mathrm{pool}^{3}$ & P/BK & 0.24 & 0.08 & 0.8 & - & - & 2.54 & 0.27 & 0.43 & 3.43 & 5.3 & 0.17 & 0.20 \\
\hline
\end{tabular}

Data for the terrestrial end-member are also provided for comparison. Values represent means \pm 1 standard deviation. 
Core $I D=$ operational identification code used by the Congolobe consortium, THAA= total hydrolysable amino acids, $\mathrm{CARB}=$ carbohydrates, $\mathrm{BPC}=$ biopolymeric carbon, $\% \mathrm{TAA}-\mathrm{N}=$ percentage of nitrogen occurring as amino acids, $\mathrm{Dl}=$ degradation index, $\mathrm{Rl}=$ reactivity index.

1: average values correspond to the arithmetic mean calculated for each $22 \mathrm{~cm}$-core sliced in 11 horizontal layers $(n=11)$ and were calculated based on data reported in the supplementary material provided by Stetten et al. (2015).

2: this study, average values correspond to the arithmetic mean calculated on 11 horizontal layers for cores COL-C-MTB-11 and COL-E-MTB-14, and 4 horizontal layers for the other cores.

3: Congo River sediments collected at the Malebo Pool (Kinshasa): permanently submerged (PS), floodplain (FP) and bank (BK) sediments from the Congo River were analysed. Values correspond to the mean of the 3 samples \pm 1 standard deviation.

Table 2: List of mega- and macrofauna from the distal lobe of the Congo deepsea fan and from the REGAB pockmark with studied tissues, mode of preservation, sampling site, habitat, operational information (cruise and dive number), collection device and analysis performed. $\mathrm{N}=$ number of individuals, SI= stable isotopes, $F A=$ fatty acids.

\begin{tabular}{|c|c|c|c|c|c|c|c|c|c|c|}
\hline Taxa & Species & $\mathbf{N}$ & Tissue & $\begin{array}{c}\text { Sto } \\
\text { rag } \\
\text { e }\end{array}$ & Site & Habitat & $\begin{array}{l}\text { Crui } \\
\text { se }\end{array}$ & $\begin{array}{l}\text { D } \\
\text { iv } \\
\text { e }\end{array}$ & $\begin{array}{l}\text { Sampl } \\
\text { ing } \\
\text { devic } \\
\text { e }\end{array}$ & $\begin{array}{l}\text { An } \\
\text { aly } \\
\text { sis }\end{array}$ \\
\hline \multirow{2}{*}{$\begin{array}{c}\text { Polychaeta } \\
- \\
\text { Dorvilleida } \\
\text { e }\end{array}$} & \multirow{2}{*}{$\begin{array}{l}\text { undetermine } \\
\mathrm{d}\end{array}$} & 3 & $\begin{array}{c}\text { without } \\
\text { digestiv } \\
\text { e tract }\end{array}$ & $\begin{array}{l}\text { Eth } \\
\text { an } \\
\text { ol } \\
96^{\circ}\end{array}$ & C & $\begin{array}{l}\text { Vesicom } \\
\text { yid bed }\end{array}$ & $\begin{array}{l}\text { WA } \\
\text { CS }\end{array}$ & $\begin{array}{l}4 \\
3 \\
6\end{array}$ & $\begin{array}{c}\text { Large } \\
\text { blade } \\
\text { core }\end{array}$ & SI \\
\hline & & 8 & $\begin{array}{l}\text { without } \\
\text { digestiv } \\
\text { e tract }\end{array}$ & $\begin{array}{c}- \\
80^{\circ} \\
C\end{array}$ & C & $\begin{array}{l}\text { Vesicom } \\
\text { yid bed }\end{array}$ & $\begin{array}{l}\text { WA } \\
\text { CS }\end{array}$ & $\begin{array}{l}4 \\
3 \\
6\end{array}$ & $\begin{array}{l}\text { Large } \\
\text { blade } \\
\text { core }\end{array}$ & FA \\
\hline \multirow{3}{*}{$\begin{array}{c}\text { Polychaeta } \\
\text { - } \\
\text { Amphareti } \\
\text { dae }\end{array}$} & \multirow{3}{*}{$\begin{array}{l}\text { undetermine } \\
\text { d }\end{array}$} & 3 & $\begin{array}{l}\text { without } \\
\text { digestiv } \\
\text { e tract }\end{array}$ & $\begin{array}{l}\text { Eth } \\
\text { an } \\
\text { ol } \\
96^{\circ}\end{array}$ & C & $\begin{array}{l}\text { Vesicom } \\
\text { yid bed }\end{array}$ & $\begin{array}{l}\text { WA } \\
\text { CS }\end{array}$ & $\begin{array}{l}4 \\
3 \\
7\end{array}$ & Net & SI \\
\hline & & 3 & $\begin{array}{l}\text { without } \\
\text { digestiv } \\
\text { e tract }\end{array}$ & $\begin{array}{l}\text { Eth } \\
\text { an } \\
\text { ol } \\
96^{\circ}\end{array}$ & A & $\begin{array}{l}\text { Vesicom } \\
\text { yid bed }\end{array}$ & $\begin{array}{l}\text { Con } \\
\text { gol } \\
\text { obe }\end{array}$ & $\begin{array}{l}4 \\
8 \\
4\end{array}$ & $\begin{array}{l}\text { Succio } \\
\text { n } \\
\text { Sampl } \\
\text { er }\end{array}$ & SI \\
\hline & & 3 & $\begin{array}{l}\text { without } \\
\text { digestiv } \\
\text { e tract }\end{array}$ & $\begin{array}{l}\text { Eth } \\
\text { an } \\
\text { ol }\end{array}$ & C & $\begin{array}{l}\text { Vesicom } \\
\text { yid bed }\end{array}$ & $\begin{array}{l}\text { Con } \\
\text { gol } \\
\text { obe }\end{array}$ & $\begin{array}{l}4 \\
9 \\
1\end{array}$ & Net & $\mathrm{SI}$ \\
\hline
\end{tabular}




\begin{tabular}{|c|c|c|c|c|c|c|c|c|c|c|}
\hline \multirow{5}{*}{$\begin{array}{l}\text { Holothuroi } \\
\text { dea - } \\
\text { Elasipodida }\end{array}$} & & & & $96^{\circ}$ & & & & & & \\
\hline & & 1 & $\begin{array}{c}\text { tegume } \\
\mathrm{nt}\end{array}$ & $\begin{array}{l}\text { Eth } \\
\text { an } \\
\text { ol } \\
96^{\circ}\end{array}$ & A & $\begin{array}{l}\text { Vesicom } \\
\text { yid bed }\end{array}$ & $\begin{array}{l}\text { Con } \\
\text { gol } \\
\text { obe }\end{array}$ & $\begin{array}{l}4 \\
8 \\
4\end{array}$ & $\begin{array}{l}\text { Succio } \\
\text { n } \\
\text { Sampl } \\
\text { er }\end{array}$ & $\mathrm{SI}$ \\
\hline & undetermine & 2 & $\begin{array}{c}\text { tegume } \\
\text { nt }\end{array}$ & $\begin{array}{c}\text { Eth } \\
\text { an } \\
\text { ol } \\
96^{\circ}\end{array}$ & C & $\begin{array}{c}\text { Backgro } \\
\text { und } \\
\text { sedimen } \\
t\end{array}$ & $\begin{array}{l}\text { Con } \\
\text { gol } \\
\text { obe }\end{array}$ & $\begin{array}{l}4 \\
9 \\
1\end{array}$ & $\begin{array}{c}\text { Succio } \\
n \\
\text { Sampl } \\
\text { er }\end{array}$ & $\mathrm{SI}$ \\
\hline & & 3 & $\begin{array}{c}\text { tegume } \\
\mathrm{nt}\end{array}$ & $\begin{array}{l}\text { Eth } \\
\text { an } \\
\text { ol } \\
96^{\circ}\end{array}$ & B & $\begin{array}{l}\text { Vesicom } \\
\text { yid bed }\end{array}$ & $\begin{array}{l}\text { Con } \\
\text { gol } \\
\text { obe }\end{array}$ & $\begin{array}{l}4 \\
9 \\
2\end{array}$ & $\begin{array}{l}\text { Succio } \\
n \\
\text { Sampl } \\
\text { er }\end{array}$ & $\mathrm{SI}$ \\
\hline & & 2 & $\begin{array}{c}\text { tegume } \\
\text { nt }\end{array}$ & $\begin{array}{c}- \\
80^{\circ} \\
C\end{array}$ & B & $\begin{array}{l}\text { Vesicom } \\
\text { yid bed }\end{array}$ & $\begin{array}{l}\text { Con } \\
\text { gol } \\
\text { obe }\end{array}$ & $\begin{array}{l}4 \\
9 \\
2\end{array}$ & $\begin{array}{l}\text { Succio } \\
\text { n } \\
\text { Sampl } \\
\text { er }\end{array}$ & FA \\
\hline $\begin{array}{l}\text { Holothuroi } \\
\text { dea - } \\
\text { Synallactid } \\
\text { ae }\end{array}$ & $\begin{array}{c}\text { Paleopatides } \\
\text { gigantea }\end{array}$ & 1 & $\begin{array}{c}\text { tegume } \\
\text { nt }\end{array}$ & $\begin{array}{l}\text { Eth } \\
\text { an } \\
\text { ol } \\
96^{\circ}\end{array}$ & C & $\begin{array}{c}\text { Backgro } \\
\text { und } \\
\text { sedimen } \\
t\end{array}$ & $\begin{array}{l}\text { Con } \\
\text { gol } \\
\text { obe }\end{array}$ & $\begin{array}{l}4 \\
9 \\
1\end{array}$ & $\begin{array}{l}\text { Succio } \\
\text { n } \\
\text { Sampl } \\
\text { er }\end{array}$ & SI \\
\hline \multirow[t]{4}{*}{ Galathea } & $\begin{array}{c}\text { Munidopsis } \\
\text { crassa }\end{array}$ & 1 & muscle & $\begin{array}{l}\text { mal } \\
\text { in- } \\
\text { Eth } \\
\text { an } \\
\text { ol } \\
80^{\circ}\end{array}$ & $\mathrm{F}$ & $\begin{array}{l}\text { Vesicom } \\
\text { yid bed }\end{array}$ & $\begin{array}{l}\text { Con } \\
\text { gol } \\
\text { obe }\end{array}$ & $\begin{array}{l}4 \\
8 \\
6\end{array}$ & $\begin{array}{l}\text { Succio } \\
\text { n } \\
\text { Sampl } \\
\text { er }\end{array}$ & $\mathrm{SI}$ \\
\hline & 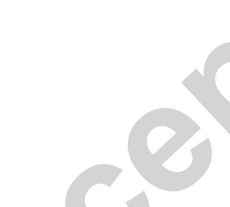 & 1 & muscle & $\begin{array}{l}\text { Eth } \\
\text { an } \\
\text { ol } \\
96^{\circ}\end{array}$ & $E$ & $\begin{array}{c}\text { Backgro } \\
\text { und } \\
\text { sedimen } \\
t\end{array}$ & $\begin{array}{l}\text { Con } \\
\text { gol } \\
\text { obe }\end{array}$ & $\begin{array}{l}4 \\
9 \\
4\end{array}$ & $\begin{array}{l}\text { Succio } \\
\text { n } \\
\text { Sampl } \\
\text { er }\end{array}$ & $\mathrm{SI}$ \\
\hline & $\begin{array}{l}\text { undetermine } \\
\text { d }\end{array}$ & 2 & $\begin{array}{c}\text { tissue } \\
\text { and foot }\end{array}$ & $\begin{array}{l}\text { Eth } \\
\text { an } \\
\text { ol } \\
96^{\circ}\end{array}$ & B & $\begin{array}{l}\text { Vesicom } \\
\text { yid bed }\end{array}$ & $\begin{array}{l}\text { Con } \\
\text { gol } \\
\text { obe }\end{array}$ & $\begin{array}{l}4 \\
9 \\
2\end{array}$ & Net & SI \\
\hline & $\begin{array}{c}\text { undetermine } \\
\text { d }\end{array}$ & 1 & $\begin{array}{c}\text { tissue } \\
\text { and foot }\end{array}$ & $\begin{array}{l}\text { Eth } \\
\text { an } \\
\text { ol } \\
96^{\circ}\end{array}$ & B & $\begin{array}{l}\text { Vesicom } \\
\text { yid bed }\end{array}$ & $\begin{array}{l}\text { Con } \\
\text { gol } \\
\text { obe }\end{array}$ & $\begin{array}{l}4 \\
9 \\
2\end{array}$ & $\begin{array}{l}\text { Succio } \\
\text { n } \\
\text { Sampl } \\
\text { er }\end{array}$ & SI \\
\hline \multirow[t]{2}{*}{ Porifera } & $\begin{array}{l}\text { undetermine } \\
d \text { (elongated }\end{array}$ & 1 & tissue & $\begin{array}{l}\text { Eth } \\
\text { an } \\
\text { ol } \\
96^{\circ}\end{array}$ & $E$ & $\begin{array}{l}\text { Backgro } \\
\text { und } \\
\text { sedimen } \\
t\end{array}$ & $\begin{array}{l}\text { Con } \\
\text { gol } \\
\text { obe }\end{array}$ & $\begin{array}{l}4 \\
9 \\
4\end{array}$ & $\begin{array}{l}\text { Succio } \\
n \\
\text { Sampl } \\
\text { er }\end{array}$ & $\mathrm{SI}$ \\
\hline & sponge) & 1 & tissue & $\begin{array}{c}- \\
80^{\circ} \\
C\end{array}$ & $E$ & $\begin{array}{c}\text { Backgro } \\
\text { und } \\
\text { sedimen }\end{array}$ & $\begin{array}{l}\text { Con } \\
\text { gol } \\
\text { obe }\end{array}$ & $\begin{array}{l}4 \\
9 \\
4\end{array}$ & $\begin{array}{c}\text { Succio } \\
\mathrm{n} \\
\text { Sampl }\end{array}$ & FA \\
\hline
\end{tabular}




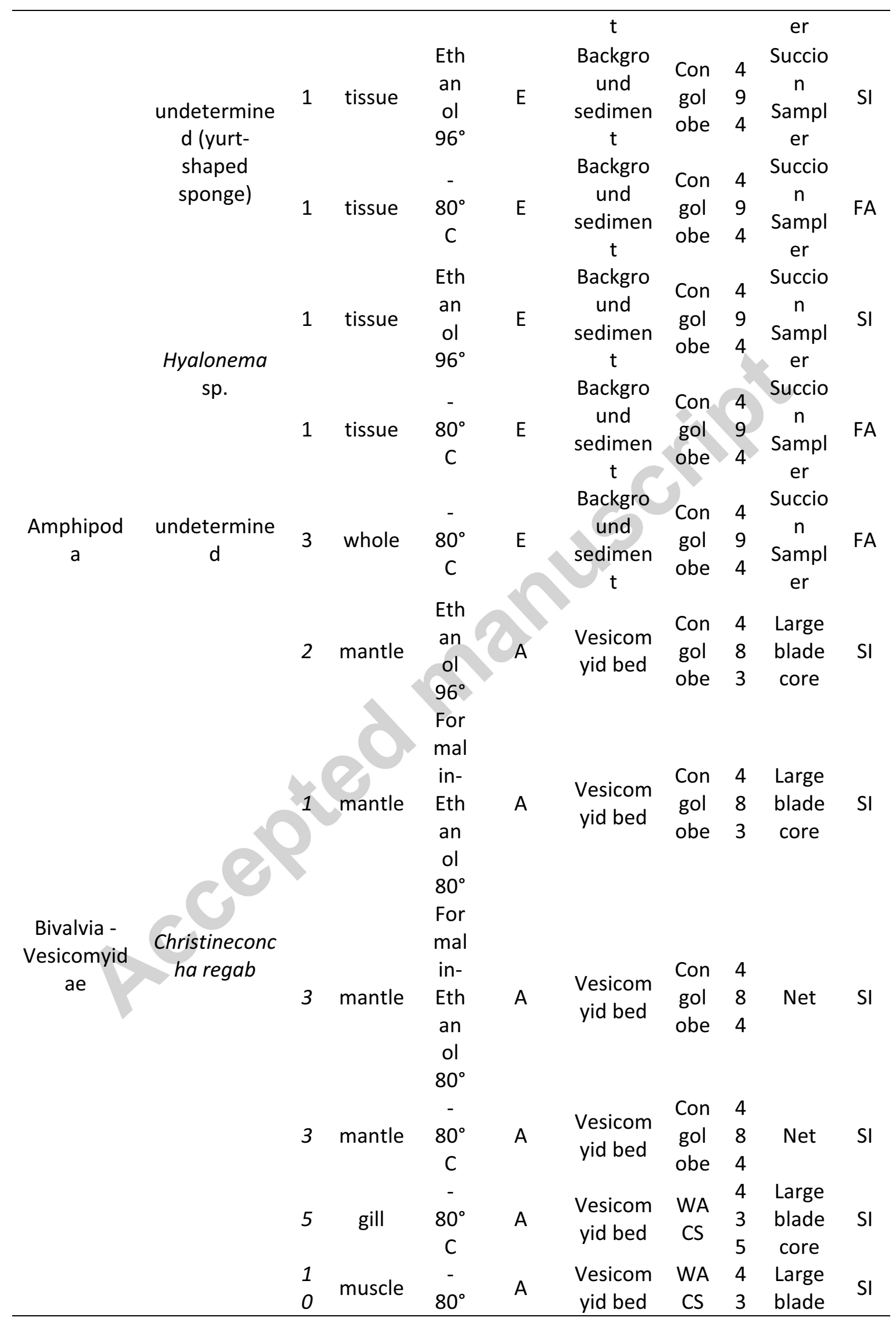




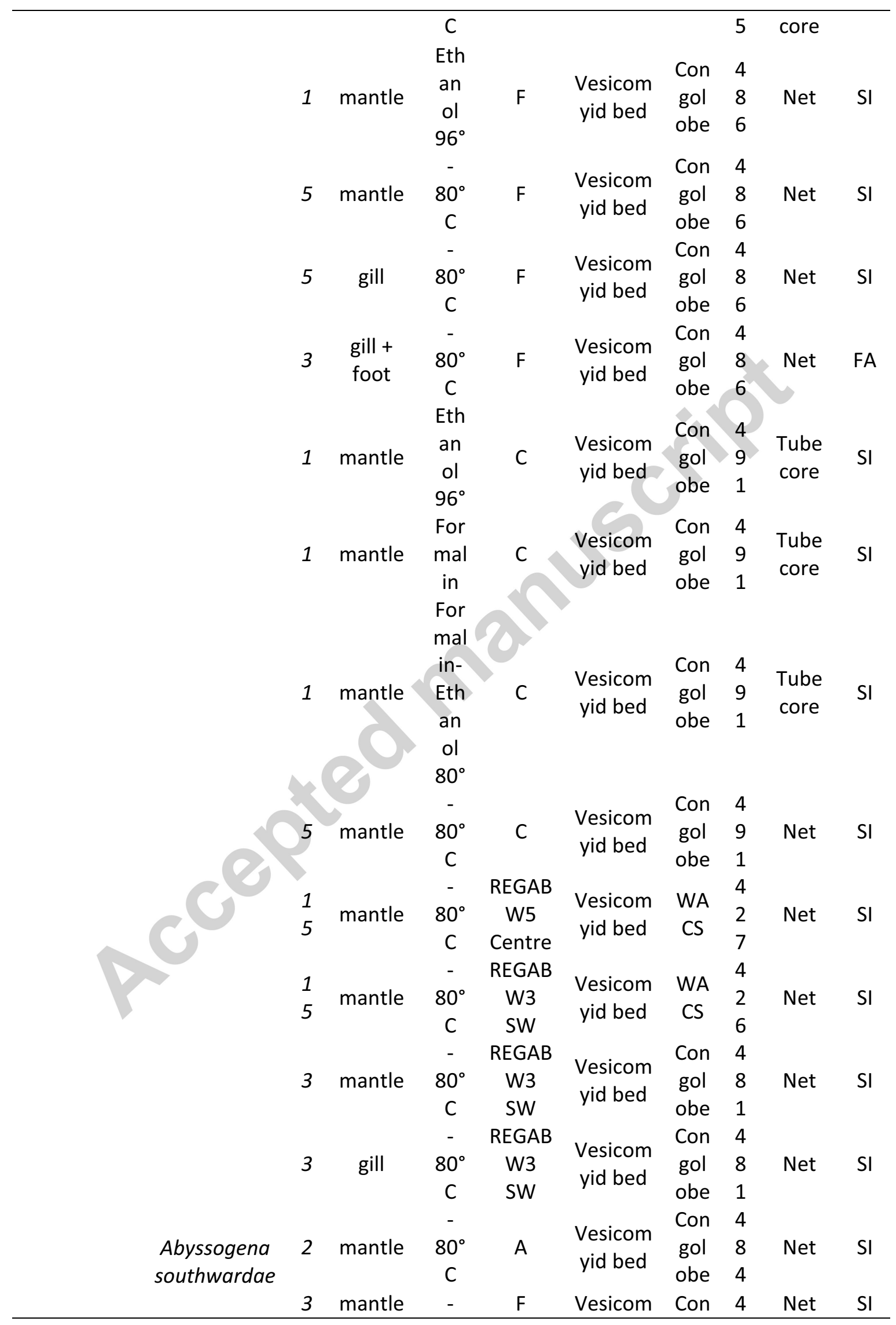




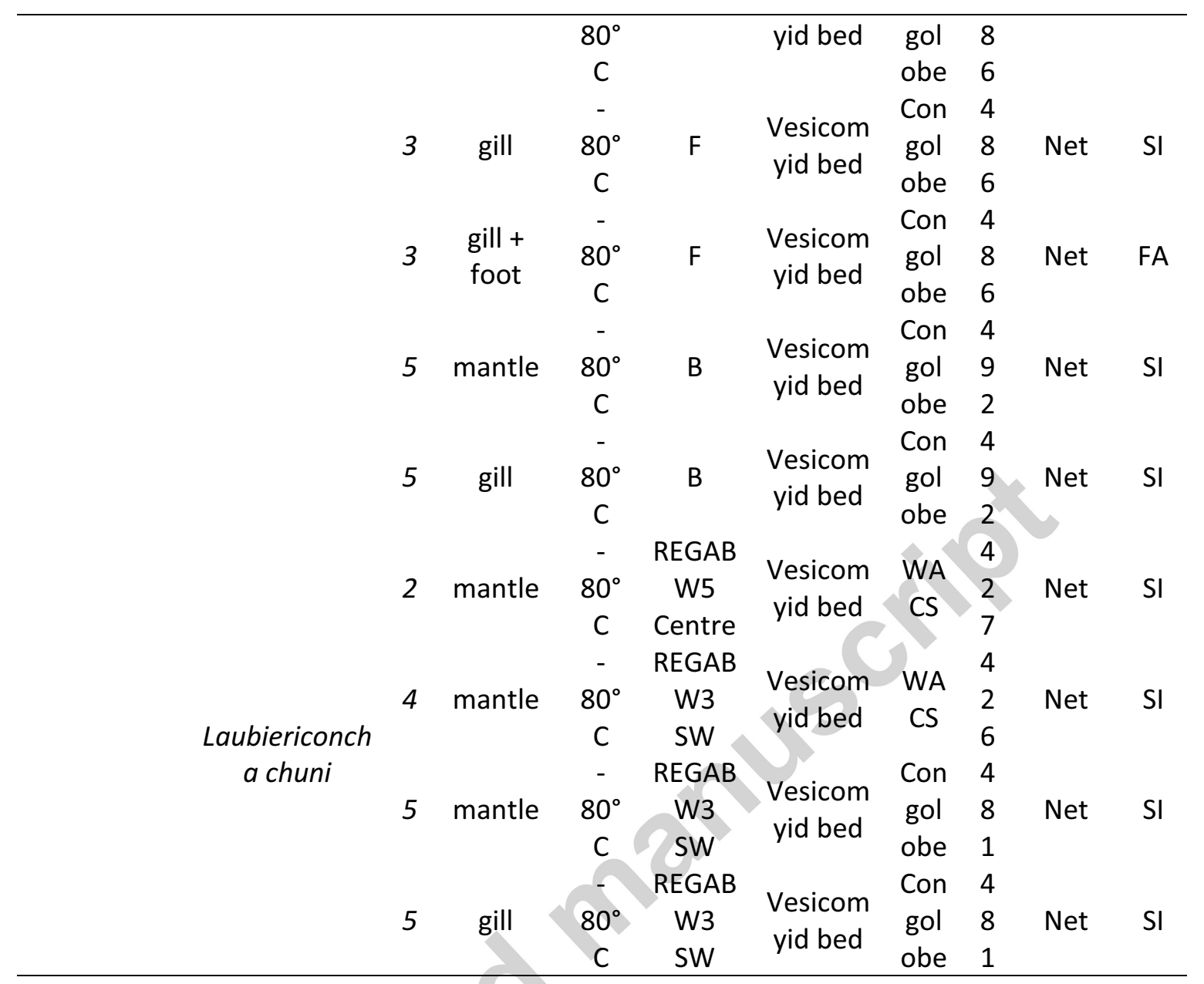

Table 3: Principal lipid biomarkers used in this study and a summary of their likely sources in the abyss.

\begin{tabular}{lll}
\hline Feature & Fatty acids & Source \\
\hline MC-SAFAs & 14:0, 16:0, 18:0 & \\
& & Unspecific [1] \\
LC-SAFAs & $24: 0,26: 0,28: 0,30: 0$ & Vascular plants [1] \\
& & Common in many bacteria, specific of \\
MC-MUFAs & $16: 1 \omega 7$ (palmitoleic acid) & thiotrophic bacteria [2] \\
& $18: 1 \omega 7$ (cis-vaccenic acid) & Generally diagnostic of bacteria, abundant in \\
& & AOM consortia and SOB [3, 4] \\
& $18: 1 \omega 9$ (oleic acid) & Animal, higher plants and algae [1] \\
& Indicator of carnivory vs herbivory [5] \\
$14: 1 \omega 9 / 18: 1 \omega 7$ & Bacteria [6] \\
$16: 1 \omega 5$ & SRB , diagnostic of AOM consortia [7]
\end{tabular}


$16: 1 \omega 6,16: 1 \omega 8$

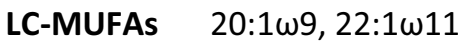

Methanotrophic bacteria [8]

Zooplankton [5]

PUFAs Usually derived from the rain of phytoplankton [9], but may also be produced locally:

20:5 $\omega 3$ (eicosapentanoic acid, EPA) Piezophilic bacteria [10]

20:4 $\omega 3$ (eicosatetraenoic acid, ETA) Intermediate of EPA biosynthesis [11]

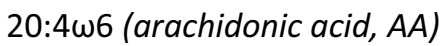

Bathysiphon sp. [12]

22:6w3 (docosahexaenoic acid, DHA) Piezophilic bacteria [10]

BAFAs

Methylbranched chains (iso and

anteiso), Odd number saturated

$(15: 0,17: 0)$, Hydroxylated (2 and 3-

$\mathrm{OH})$, Cyclopropyl $\left(17: 0^{\perp}, 19: 0^{\perp}\right)$

MC-SAFAs: Mid-chain even number saturated fatty acids, LC-SAFAs: Long-chain saturated fatty acids, MC-MUFAs: mid-chain monounsaturated fatty acids $\left(\mathrm{C}_{\leq 18}\right)$, LC-MUFAs: Iong-chain monounsaturated fatty acids $\left(C_{\geq 20}\right)$, PUFAs: polyunsaturated fatty acids.

$\mathrm{AOM}=$ anaerobic oxidation of methane, $\mathrm{SOB}=$ sulphide-oxidising bacteria, $\mathrm{SRB}=$ sulphate-reducing bacteria.

[1] Bianchi and Canuel (2011), [2] Conway and McDowell Capuzzo (1991), [3] Thurber et al. (2013), [4] McCaffrey et al. (1989), [5] Dalsgaard et al. (2003), [6] Findlay et al. (1990), [7] Elvert et al. (2003), [8] Bowman et al. (1991), [9] Hudson et al. (2004), [10] Nichols et al. (2003), [11] Leonard et al. (2004), [12] Gooday et al. (2002).

Table 4 : Relative abundances of fatty acids in taxa from the distal lobe complex of the Congo deep-sea fan.

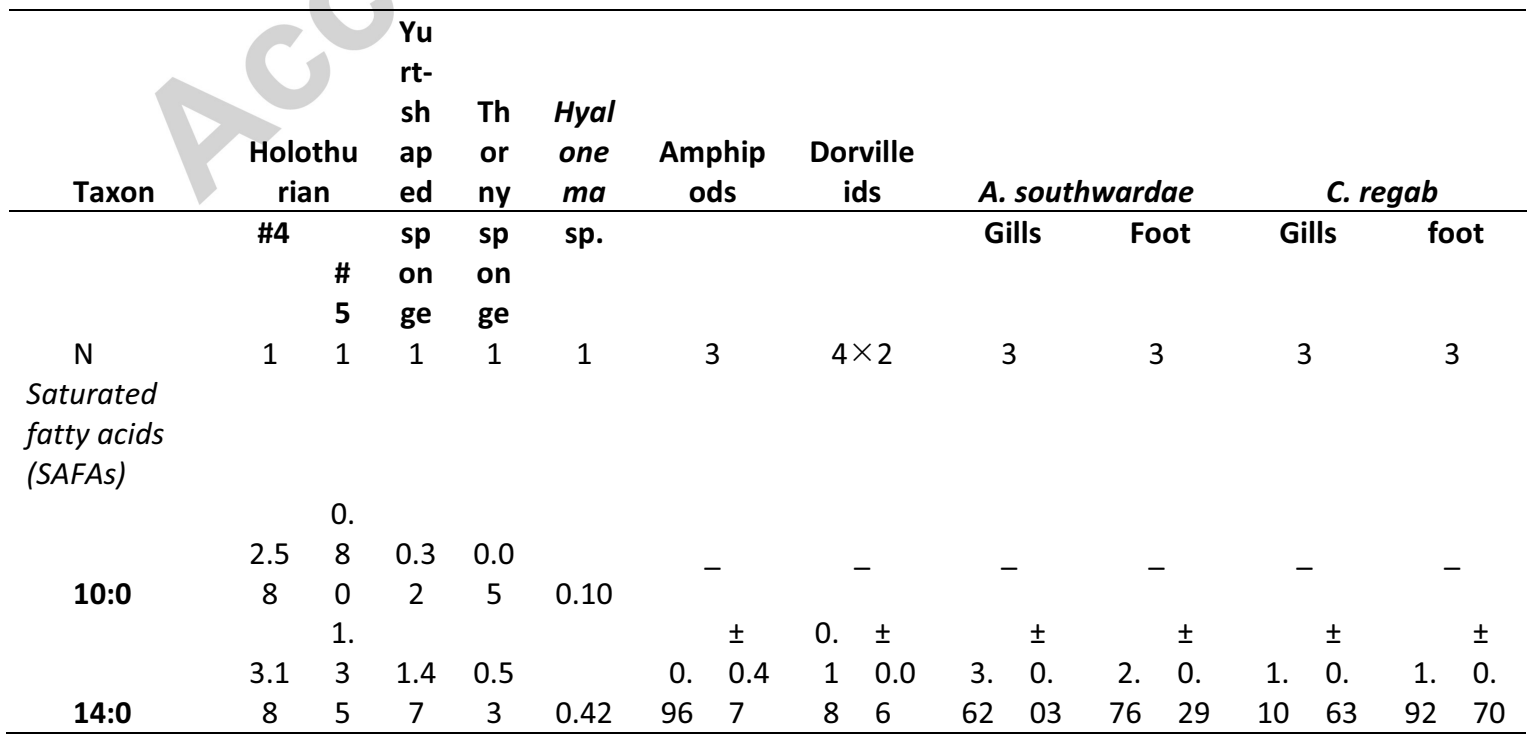




\begin{tabular}{|c|c|c|c|c|c|c|c|c|c|c|c|c|c|c|c|c|c|}
\hline & & 1 & & & & & & & & & & & & & & & \\
\hline & & 1. & & & & & \pm & 7. & \pm & & \pm & & \pm & & \pm & & \pm \\
\hline & 21. & 4 & 6.6 & 1.7 & & 8. & 1.9 & 3 & 0.7 & 5. & 0. & 9. & 0. & 7. & 0. & 9. & 0. \\
\hline 16:0 & 96 & 4 & 8 & 8 & 1.49 & 68 & 1 & 2 & 4 & 90 & 22 & 42 & 49 & 66 & 32 & 48 & 35 \\
\hline & & 5. & & & & & \pm & 1. & \pm & & \pm & & \pm & & \pm & & \pm \\
\hline & 16. & 7 & 4.8 & 5.2 & & 0. & 0.2 & 0 & 0.2 & 1. & 0. & 1. & 0. & 0. & 0. & 1. & 0. \\
\hline 18:0 & 42 & 5 & 8 & 2 & 7.50 & 69 & 2 & 9 & 1 & 23 & 08 & 75 & 15 & 44 & 20 & 21 & 08 \\
\hline & & 2. & & & & & \pm & 0. & \pm & & \pm & & \pm & & & & \pm \\
\hline & 0.6 & 0 & 0.5 & 0.1 & & 0. & 0.0 & 0 & 0.0 & 0. & 0. & 0. & 0. & & - & 0. & 0. \\
\hline 20:0 & 2 & 5 & 0 & 1 & 0.03 & 04 & 0 & 3 & 0 & 03 & 00 & 13 & 02 & & & 03 & 01 \\
\hline $\begin{array}{l}\text { Mono unsatu } \\
\text { fatty acids ( }\end{array}$ & & & & & & & & & & & & & & & & & \\
\hline & & 0. & & & & & \pm & 0. & \pm & & \pm & & & & \pm & & \\
\hline & 5.0 & 6 & 0.0 & 0.0 & & 0. & 0.0 & 0 & 0.0 & 0. & 0. & & & 0. & 0. & & \\
\hline $14: 1 \omega 7$ & 1 & 6 & 9 & 6 & 0.03 & 04 & 1 & 5 & 2 & 29 & 04 & 1 & T & 04 & 01 & & T \\
\hline & & 3. & & & & & \pm & 5. & \pm & 51 & \pm & 14 & \pm & 46 & \pm & 11 & \pm \\
\hline & 15. & 0 & 2.8 & 2.4 & & 2. & 0.6 & 2 & 3.3 & .2 & 2. & .6 & 0. & .3 & 0. & .9 & 0. \\
\hline $16: 1 \omega 7$ & 71 & 1 & 8 & 9 & 0.48 & 60 & 3 & 1 & 9 & 6 & 70 & 2 & 66 & 6 & 33 & 4 & 94 \\
\hline & & 0. & & & & & \pm & 1. & \pm & & \pm & & \pm & & \pm & & \pm \\
\hline & 0.3 & 2 & 1.0 & 0.6 & & 0. & 0.1 & 4 & 0.4 & 0. & 0. & 0. & 0. & 0. & 0. & 0. & 0. \\
\hline $16: 1 \omega 5$ & 1 & 5 & 6 & 4 & 0.55 & 31 & 8 & 9 & 9 & 32 & 02 & 86 & 11 & 89 & 20 & 28 & 02 \\
\hline & & & & & & & & 1. & \pm & & \pm & & \pm & & \pm & & \pm \\
\hline & & & & & & & & 0 & 0.2 & 0. & 0. & 0. & 0. & 0. & 0. & 0. & 0. \\
\hline $18: 1 \omega x$ & - & - & - & - & _ & - & & 0 & 7 & 28 & 07 & 98 & 10 & 26 & 06 & 64 & 04 \\
\hline & & 3. & & & & 10 & \pm & 2. & \pm & 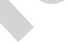 & \pm & & \pm & & \pm & & \pm \\
\hline $18: 1 \omega 9$ & 7.4 & 4 & 7.1 & 2.2 & & .5 & 1.6 & 6 & 0.2 & 0 & 0. & 0. & 0. & 0. & 0. & 0. & 0. \\
\hline cis & 0 & 2 & 3 & 9 & 4.43 & 8 & 6 & 2 & 3 & 07 & 09 & 09 & 01 & 03 & 02 & 11 & 01 \\
\hline & & 1. & & & & & \pm & 5. & \pm & & \pm & & \pm & & \pm & & \pm \\
\hline & 5.2 & 2 & 3.3 & 10. & & 7. & 3.8 & 7 & 2.4 & 3. & 0. & 3. & 0. & 5. & 0. & 3. & 0. \\
\hline $18: 1 \omega 7$ & 4 & 6 & 6 & 40 & 9.74 & 64 & 6 & 0 & 4 & 47 & 69 & 53 & 39 & 26 & 80 & 91 & $4 \varepsilon$ \\
\hline & & & & & & & \pm & 1. & \pm & & \pm & & \pm & & \pm & & \pm \\
\hline & 0.4 & & 0.9 & 0.7 & 3 & 1. & 0.9 & 0 & 0.3 & 0. & 0. & 0. & 0. & 0. & 0. & 0. & 0. \\
\hline $18: 1 \omega 5$ & 0 & $\mathrm{~T}$ & 1 & 1 & 0.69 & 97 & 3 & 2 & 4 & 13 & 01 & 55 & 09 & 24 & 02 & 24 & 01 \\
\hline & & & & & & & \pm & 2. & \pm & & \pm & & \pm & & \pm & & \pm \\
\hline & & & 0.4 & 0.2 & & 1. & 1.5 & 3 & 0.4 & 3. & 0. & 6. & 0. & 4. & 0. & 5. & 0. \\
\hline 20:1w11 & $\mathrm{T}$ & T & 2 & 7 & 0.16 & 29 & 2 & 0 & 3 & 34 & 08 & 63 & 29 & 00 & 02 & 78 & 26 \\
\hline & & 0. & & & & & \pm & 0. & \pm & & \pm & & \pm & & \pm & & \pm \\
\hline & 0.2 & 9 & 0.9 & 0.5 & & 1. & 0.3 & 2 & 0.0 & 0. & 0. & 2. & 0. & 0. & 0. & 3. & 0. \\
\hline $20: 1 \omega 9$ & 1 & 2 & 9 & 1 & 0.47 & 08 & 0 & 8 & 4 & 50 & 06 & 85 & 03 & 97 & 44 & 41 & 14 \\
\hline & & 1. & & & & & \pm & 2. & \pm & & \pm & 13 & \pm & & \pm & 13 & \pm \\
\hline & 0.5 & 5 & 1.8 & 0.6 & & 5. & 1.7 & 9 & 0.5 & 8. & 0. & .3 & 0. & 8. & 1. & .0 & 0. \\
\hline $20: 1 \omega 7$ & 6 & 5 & 1 & 2 & 0.62 & 46 & 8 & 7 & 5 & 49 & 41 & 7 & 49 & 23 & 20 & 7 & 22 \\
\hline & & 0. & & & & & \pm & & & & & & & & \pm & & \pm \\
\hline & & 1 & 0.7 & 0.6 & & 0. & 0.1 & & & & _ & - & & 0. & 0. & 0. & 0. \\
\hline 22:1w9 & _- & 0 & 0 & 1 & 0.54 & 50 & 1 & & _ & & & & & 07 & 02 & 42 & $0 \varepsilon$ \\
\hline & & 0. & & & & & \pm & 0. & \pm & & \pm & & \pm & & \pm & & \pm \\
\hline & - & 0 & 1.4 & 1.3 & & 0. & 0.0 & 1 & 0.0 & 0. & 0. & 1. & 0. & 1. & 0. & 4. & 0. \\
\hline $22: 1 \omega 7$ & & 3 & 5 & 8 & 0.88 & 53 & 5 & 1 & 3 & 29 & 01 & 04 & 03 & 11 & 27 & 85 & 13 \\
\hline & & 3. & & & & & \pm & & & & & & & & \pm & & \pm \\
\hline & _ & 4 & 0.5 & 0.8 & & 0. & 0.0 & & & & _ & - & & 0. & 0. & 0. & 0. \\
\hline $24: 1 \omega 9$ & & 1 & 7 & 5 & 0.51 & 15 & 8 & & - & & & & & 02 & 00 & 12 & 02 \\
\hline & & & 8.3 & 7.3 & & & & & & & & & & & & & \\
\hline $24: 1 \omega x$ & - & - & 0 & 6 & 1.88 & - & - & & - & - & - & - & & & - & . & - \\
\hline Polyunsatur & & & & & & & & & & & & & & & & & \\
\hline
\end{tabular}




\begin{tabular}{|c|c|c|c|c|c|c|c|c|c|c|c|c|c|c|c|c|c|}
\hline \multicolumn{18}{|c|}{ fatty acids (PUFAs) } \\
\hline & & 0. & & & & & \pm & 0. & \pm & & \pm & & \pm & & \pm & & \pm \\
\hline & 0.6 & 0 & 0.0 & 0.0 & - & 0. & 0.0 & 4 & 0.1 & 0. & 0. & 0. & 0. & 0. & 0. & 0. & 0. \\
\hline \multirow[t]{2}{*}{$16: 2 \omega 4$} & 7 & 1 & 3 & 3 & & 06 & 4 & 0 & 0 & 02 & 00 & 02 & 00 & 02 & 00 & 03 & 00 \\
\hline & & 1. & & & & & \pm & 1. & \pm & & \pm & & & & & & \pm \\
\hline $18: 2 \omega 6$ & 0.7 & 0 & 1.2 & 0.3 & & 1. & 0.7 & 2 & 0.2 & 0. & 0. & 0. & & 0. & & 0. & 0. \\
\hline \multirow[t]{3}{*}{ cis } & 4 & 3 & 2 & 0 & 0.28 & 37 & 6 & 1 & 6 & 07 & 12 & 01 & & 01 & & 02 & 01 \\
\hline & & & & & & & \pm & 7. & \pm & & \pm & & \pm & & \pm & & \pm \\
\hline & _ & _- & 0.0 & 0.0 & & 0. & 0.2 & 1 & 1.1 & 0. & 0. & 0. & 0. & 0. & 0. & 0. & 0. \\
\hline \multirow[t]{3}{*}{$18: 2 \omega 4$} & & & 6 & 9 & 0.05 & 32 & 3 & 6 & 6 & 11 & 03 & 20 & 02 & 13 & 04 & 22 & 03 \\
\hline & & & & & & & & 1. & \pm & & & & & & & & \\
\hline & & & & & & & & 6 & 0.3 & & & & & & & & \\
\hline \multirow[t]{3}{*}{$18: 3 \omega 4$} & T & T & & & & & & 6 & 4 & & - & & & & & & \\
\hline & & 0. & & & & & \pm & 1. & \pm & & \pm & & \pm & & \pm & & \pm \\
\hline & & 1 & 0.8 & 0.6 & & 0. & 0.2 & 6 & 0.0 & 0. & 0. & 0. & 0. & 0. & 0. & 0. & 0. \\
\hline \multirow[t]{3}{*}{$20: 2 \omega 6$} & & 1 & 9 & 6 & 0.84 & 96 & 7 & 4 & 5 & 02 & 00 & 04 & 01 & 01 & 01 & 02 & 00 \\
\hline & & 0. & & & & & \pm & 1. & \pm & & \pm & & \pm & & \pm & & \pm \\
\hline & & 2 & 0.0 & 0.0 & & 0. & 0.0 & 7 & 0.2 & 0. & 0. & 0. & 0. & 0. & 0. & 0. & 0. \\
\hline \multirow[t]{3}{*}{$20: 3 \omega 6$} & $\mathrm{~T}$ & 6 & 9 & 7 & 0.08 & 11 & 5 & 7 & 4 & 14 & 00 & 15 & 01 & 18 & 05 & 17 & 02 \\
\hline & & 2 & & & & & & & & & & & & & & & \\
\hline & & 3. & & & & & \pm & 1. & \pm & & \pm & & \pm & & \pm & & \pm \\
\hline $20: 4 \omega 6$ & 4.7 & 6 & 12. & 16. & 18.9 & 6. & 2.1 & 9 & 0.1 & 0. & 0. & 0. & 0. & 0. & 0. & 0. & 0. \\
\hline \multirow[t]{2}{*}{ (AA) } & 9 & 7 & 47 & 11 & 6 & 21 & 8 & 9 & 5 & 07 & 01 & 05 & 01 & 09 & 03 & 04 & 01 \\
\hline & & & & & & & \pm & 0. & \pm & & & & & & & & \\
\hline \multirow{2}{*}{$20: 3 \omega 3$} & - & - & - & - & - & 4. & 1.6 & 2 & 0.0 & & & . & & & - & & - \\
\hline & & 0 & & & & & \pm & 9. & \pm & 17 & \pm & 37 & \pm & 19 & \pm & 39 & \pm \\
\hline $20: 4 \omega 3$ & & 0 & 0.2 & 0.0 & & 0. & 0.0 & 4 & 8.8 & .5 & 2. & .6 & 1. & .6 & 1. & .5 & 1. \\
\hline \multirow[t]{3}{*}{ (ETA) } & T & 3 & 5 & 5 & 0.09 & 19 & 4 & 6 & 4 & 4 & 74 & 5 & 41 & 2 & 01 & 6 & 57 \\
\hline & & & & & & & & 2 & & & & & & & & & \\
\hline & & 3. & & & & 17 & \pm & 0. & \pm & & \pm & & \pm & & \pm & & \pm \\
\hline $20: 5 \omega 3$ & - & 3 & 22. & 30. & 34.6 & .2 & 5.8 & 1 & 4.5 & 0. & 0. & 0. & 0. & 0. & 0. & 0. & 0. \\
\hline \multirow{3}{*}{ (EPA) } & & 2 & 71 & 48 & 5 & 1 & 3 & 8 & 3 & 06 & 01 & 27 & 10 & 06 & 02 & 13 & 03 \\
\hline & & 0. & & & 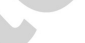 & & \pm & 0. & \pm & & \pm & & \pm & & & & \\
\hline & - & 1 & 0.8 & 0.1 & & 1. & 0.4 & 5 & 0.2 & 0. & 0. & 0. & 0. & & & & \\
\hline \multirow[t]{3}{*}{$22: 4 \omega 6$} & & 1 & 9 & 7 & 0.14 & 22 & 4 & 4 & 2 & 02 & 00 & 03 & 00 & & $\mathrm{~T}$ & & T \\
\hline & & 1. & 3 & V & & & \pm & 0. & \pm & & \pm & & \pm & & & & \pm \\
\hline & 0.3 & 7 & 0.2 & 0.1 & & 0. & 0.0 & 2 & 0.1 & 0. & 0. & 0. & 0. & & & 0. & 0. \\
\hline \multirow[t]{3}{*}{$22: 5 \omega 6$} & 0 & 0 & 9 & 5 & 0.17 & 32 & 4 & 9 & 0 & 05 & 01 & 24 & 02 & & T & 22 & 02 \\
\hline & & & & & & & & & & & \pm & & \pm & & \pm & & \pm \\
\hline & & - & - & - & - & & & & & 0. & 0. & 0. & 0. & 0. & 0. & 0. & 0. \\
\hline $22: 4 \omega 3$ & & & & & & & T & & $T$ & 40 & 11 & 98 & 07 & 57 & 13 & 78 & 20 \\
\hline & & 0. & & & & & \pm & 1. & \pm & & \pm & & \pm & & & & \\
\hline & & 1 & 1.3 & 1.2 & & 2. & 1.3 & 1 & 0.5 & 0. & 0. & 0. & 0. & & - & & - \\
\hline 22:5w3 & & 9 & 8 & 2 & 1.11 & 60 & 4 & 7 & 4 & 03 & 01 & 05 & 01 & & & & \\
\hline & & 2 & & & & & & & & & & & & & & & \\
\hline & & 2. & & & & 18 & \pm & 0. & \pm & & \pm & & \pm & & & & \pm \\
\hline 22:6w3 & 7.5 & 8 & 7.8 & 10. & 10.4 & .8 & 9.1 & 0 & 0.0 & 0. & 0. & 0. & 0. & & - & 0. & 0. \\
\hline (DHA) & 4 & 7 & 8 & 66 & 7 & 4 & 4 & 8 & 1 & 06 & 01 & 08 & 03 & & & 03 & 01 \\
\hline $\begin{array}{l}\text { Specific bac } \\
\text { fatty acids }\end{array}$ & & & & & & & & & & & & & & & & & \\
\hline & & 1. & & & & & \pm & 0. & \pm & & \pm & & \pm & & \pm & & \pm \\
\hline & 1.5 & 1 & 0.7 & 0.2 & & 0. & 0.0 & 0 & 0.0 & 0. & 0. & 0. & 0. & 0. & 0. & 0. & 0. \\
\hline 15:0 & 4 & 6 & 4 & 2 & 0.17 & 53 & 6 & 3 & 0 & 67 & 03 & 01 & 00 & 46 & 13 & 01 & 00 \\
\hline & 0.7 & 1. & 1.9 & 1.1 & & 0. & \pm & 0. & \pm & & \pm & & \pm & & \pm & & \\
\hline $17: 0$ & 7 & 9 & 2 & 0 & 1.10 & 39 & 0.0 & 0 & 0.0 & 0. & 0. & 0. & 0. & 0. & 0. & & - \\
\hline
\end{tabular}




\begin{tabular}{|c|c|c|c|c|c|c|c|c|c|c|c|c|c|c|c|c|c|}
\hline & & 4 & & & & & 7 & 5 & 1 & 20 & 04 & 10 & 02 & 21 & 07 & & \\
\hline & & 0. & & & & & \pm & 0. & \pm & & & & & & & & \\
\hline \multirow{4}{*}{ i $16: 0$} & & 1 & 0.7 & 0.2 & & 0. & 0.0 & 0 & 0.0 & \multirow{2}{*}{\multicolumn{2}{|c|}{-}} & & & \multirow{2}{*}{\multicolumn{2}{|c|}{ - }} & \multicolumn{2}{|c|}{ - } \\
\hline & $\mathrm{T}$ & 4 & 4 & 9 & 0.12 & 22 & 6 & 1 & 0 & & & \multicolumn{2}{|c|}{$\mathrm{T}$} & & & & \\
\hline & & 0. & & & & & \pm & 0. & \pm & & & & & & & & \\
\hline & & 5 & 0.8 & 0.2 & & 0. & 0.1 & 0 & 0.0 & \multirow{2}{*}{\multicolumn{2}{|c|}{-}} & \multicolumn{2}{|c|}{-} & & & & \\
\hline \multirow[t]{3}{*}{ i 17:0 } & $\mathrm{T}$ & 5 & 5 & 5 & 0.09 & 39 & 5 & 4 & 0 & & & & & 7 & & & $\mathrm{~T}$ \\
\hline & & 0. & & & & & \pm & 0. & \pm & & & & & & & & \\
\hline & 0.1 & 1 & 0.7 & 0.3 & & 0. & 0.0 & 0 & 0.0 & \multirow{2}{*}{\multicolumn{2}{|c|}{ - }} & & & \multirow{2}{*}{\multicolumn{2}{|c|}{-}} & \multicolumn{2}{|c|}{-} \\
\hline \multirow[t]{3}{*}{ ai $17: 0$} & 2 & 1 & 9 & 3 & 0.06 & 12 & 6 & 1 & 1 & & & 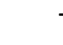 & $\Gamma$ & & & & \\
\hline & & 0. & & & & & \pm & & & & & & & & & & \\
\hline & & 8 & 0.4 & 0.3 & & 0. & 0.0 & & & \multicolumn{2}{|c|}{ _ } & \multicolumn{2}{|c|}{ - } & \multirow{2}{*}{\multicolumn{2}{|c|}{-}} & \multicolumn{2}{|c|}{ - } \\
\hline \multirow[t]{3}{*}{ i $18: 0$} & $\mathrm{~T}$ & 9 & 6 & 2 & 0.11 & 16 & 8 & \multirow{2}{*}{\multicolumn{2}{|c|}{-}} & & & & & & & & \\
\hline & & 0. & & & & & & & & & & & & & & & \\
\hline & 1.5 & 0 & 0.0 & 0.0 & & _- & & & - & & & & & & & & _- \\
\hline \multirow[t]{3}{*}{ 3-OH-12 } & 4 & 5 & 3 & 1 & $\mathrm{~T}$ & & & & & & & 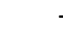 & $\Gamma$ & & & & \\
\hline & & 4. & & & & & \pm & & & & & & & & & & \\
\hline & 1.0 & 1 & 0.0 & & _ & 0. & 0.1 & & & - & & & & & & & _ \\
\hline 2-OH-16 & 8 & 4 & 2 & $\mathrm{~T}$ & & 22 & 4 & & - & & & & & & & & \\
\hline & & & & & & & \pm & & & & \pm & & & & \pm & & \pm \\
\hline & _- & _- & _- & _ & _ & 0. & 0.0 & & & 0. & 0. & 0. & 0. & 0. & 0. & 0. & 0. \\
\hline $19: 0^{\Delta}$ & - & - & - & - & - & 41 & 9 & & - & 86 & 20 & 91 & 15 & 96 & 20 & 52 & 01 \\
\hline & & 2 & & & & & & & & & & & & & & & \\
\hline SSAFAC & & 2. & & & & 10 & \pm & 8. & \pm & 10 & \pm & 14 & \pm & & \pm & 12 & \pm \\
\hline 2SAFAS & 45. & 6 & 15. & 7.9 & & .4 & 2.4 & 6 & 0.9 & .9 & 0. & .0 & 0. & 9. & 0. & .6 & 0. \\
\hline & 64 & 2 & 10 & 7 & 9.84 & 8 & 9 & 3 & 1 & 5 & 25 & 7 & 50 & 29 & 55 & 6 & 35 \\
\hline EMC- & & 8. & & & & 23 & \pm & $\begin{array}{l}3 \\
7 .\end{array}$ & \pm & 55 & \pm & 20 & \pm & 53 & \pm & 17 & \pm \\
\hline MUFAs & 34. & 7 & 15. & 16. & 16.2 & .2 & 6.1 & 1 & 2.5 & .9 & 2. & .8 & 0. & .3 & 0. & .2 & 1. \\
\hline$\left(C_{\leq 18}\right)$ & 18 & 5 & 52 & 84 & 1 & 4 & 5 & 2 & 7 & 4 & 87 & 2 & 88 & 8 & 81 & 9 & 40 \\
\hline$\Sigma L C-$ & & 6. & & & & & \pm & 5. & \pm & 12 & \pm & 23 & \pm & 14 & \pm & 27 & \pm \\
\hline MUFAs & 0.7 & 0 & 14. & 11. & & 9. & 2.9 & 6 & 1.0 & .6 & 0. & .8 & 0. & .5 & 0. & .7 & 0. \\
\hline$\left(C_{\geq 20}\right)$ & 7 & 2 & 25 & 60 & 5.06 & 11 & 1 & 5 & 2 & 1 & 39 & 9 & 62 & 6 & 86 & 8 & 59 \\
\hline & & 5 & & & & & & 4 & & & & & & & & & \\
\hline & & 3. & & & & 54 & \pm & 8. & \pm & 18 & \pm & 40 & \pm & 21 & \pm & 41 & \pm \\
\hline & 14. & 4 & 48. & 60. & 67.0 & .5 & 11. & 1 & 3.3 & .7 & 2. & .2 & 1. & .1 & 0. & .7 & 1. \\
\hline ¿PUFAs & 05 & 6 & 53 & 32 & 1 & 8 & 38 & 7 & 1 & 8 & 96 & 1 & 48 & 5 & 96 & 4 & 65 \\
\hline & & 9. & & & & & \pm & 0. & \pm & & \pm & & \pm & & \pm & & \pm \\
\hline ¿BAFAs & 5.3 & 1 & 6.6 & 3.2 & & 2. & 0.1 & 4 & 0.1 & 1. & 0. & 1. & 0. & 1. & 0. & 0. & 0. \\
\hline & 7 & 5 & 1 & 7 & 1.88 & 59 & 1 & 3 & 0 & 72 & 23 & 02 & 13 & 63 & 40 & 53 & 01 \\
\hline & & & & & & & & 6 & & & & & & & & & \\
\hline & & 0. & & & & 11 & \pm & 5. & \pm & 38 & \pm & 25 & \pm & 26 & \pm & 28 & \pm \\
\hline$\Sigma F A\left(m g . g^{-}\right.$ & 0.2 & 6 & 0.9 & 3.7 & & 2. & 31. & 6 & 17. & .3 & 2. & .3 & 1. & .1 & 7. & .5 & 2. \\
\hline${ }^{1}$ DW) & 2 & 4 & 8 & 4 & 4.22 & 46 & 36 & 6 & 55 & 3 & 71 & 6 & 58 & 8 & 03 & 4 & 63 \\
\hline
\end{tabular}

A total of 71 fatty acids have been identified and quantified, but only fatty acids that contribute to more than $0.5 \%$ in at least one taxon are presented. Fatty acids contributed to more than $10 \%$ are highlighted in bold. Values represent means \pm 1 standard deviation. Total fatty acid concentrations ( $\Sigma F A)$ account for the sum of the 71 fatty acids analysed. Note that NMID fatty acids have not been analysed. 
$\mathrm{N}=$ number of individuals, $\mathrm{T}=$ trace amounts, $\# 4$ and $\# 5$ are operational codes corresponding to the sampling net number. For the dorvilleids, each of the four analyses corresponds to two worms that have been pooled. 


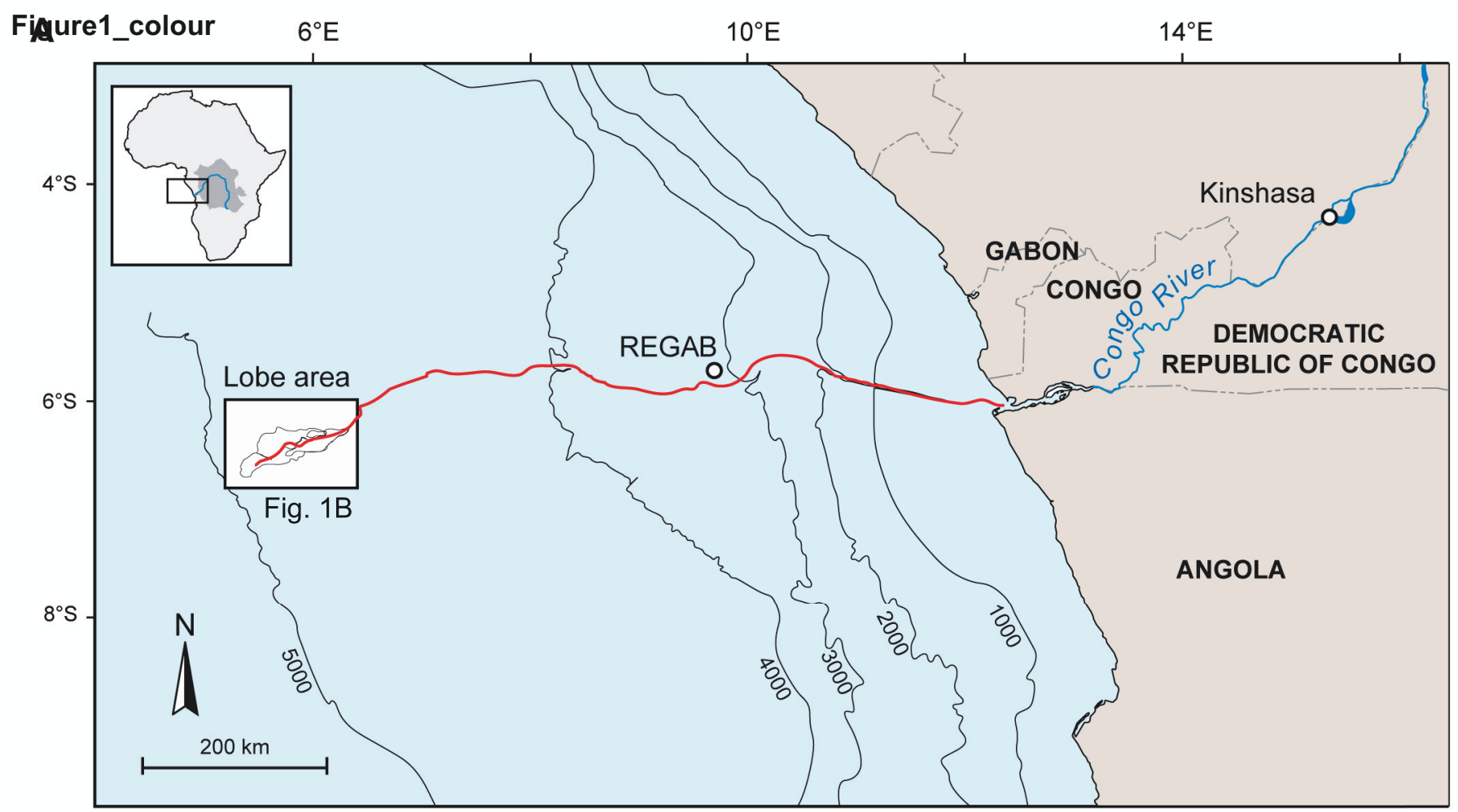

B

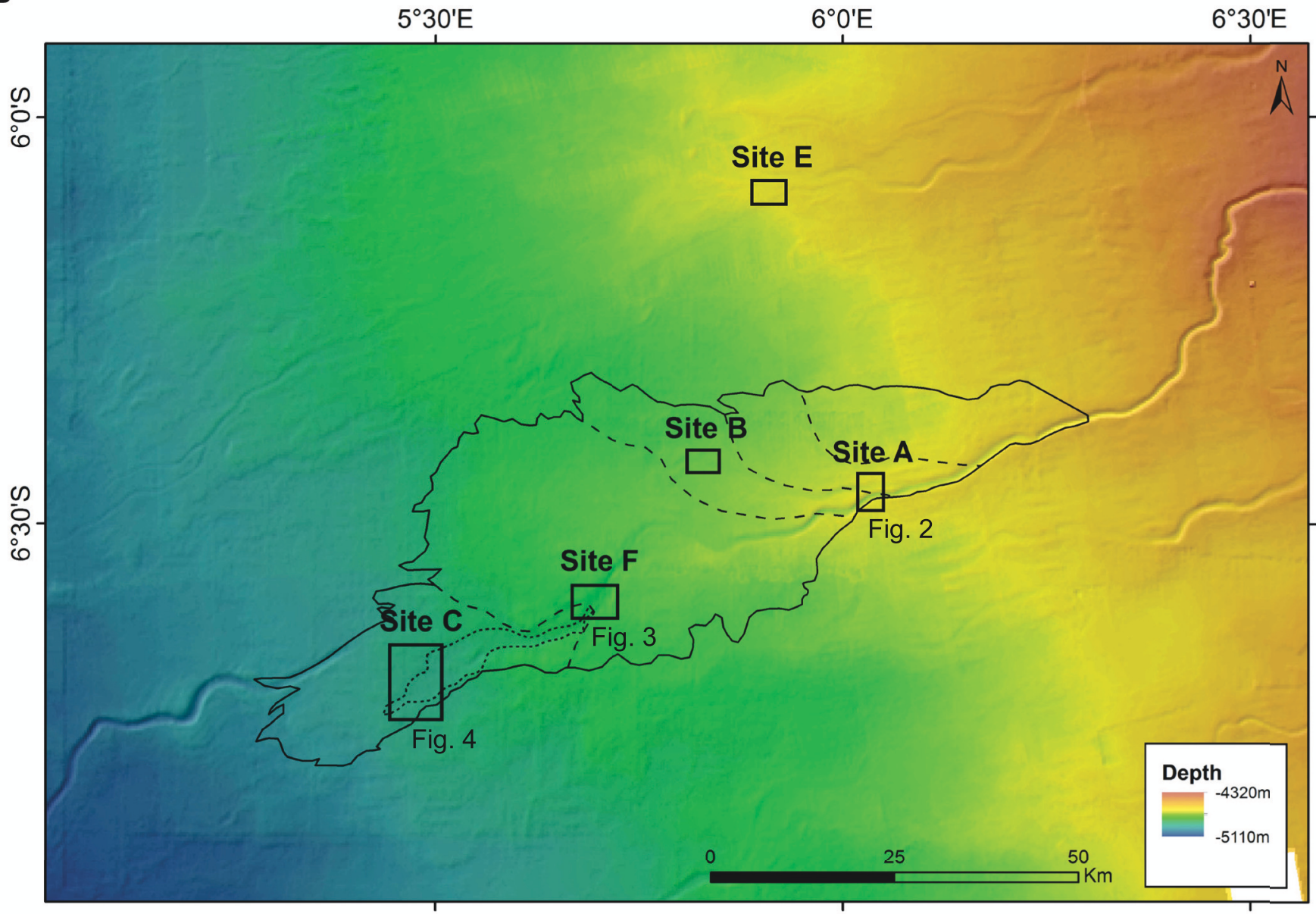




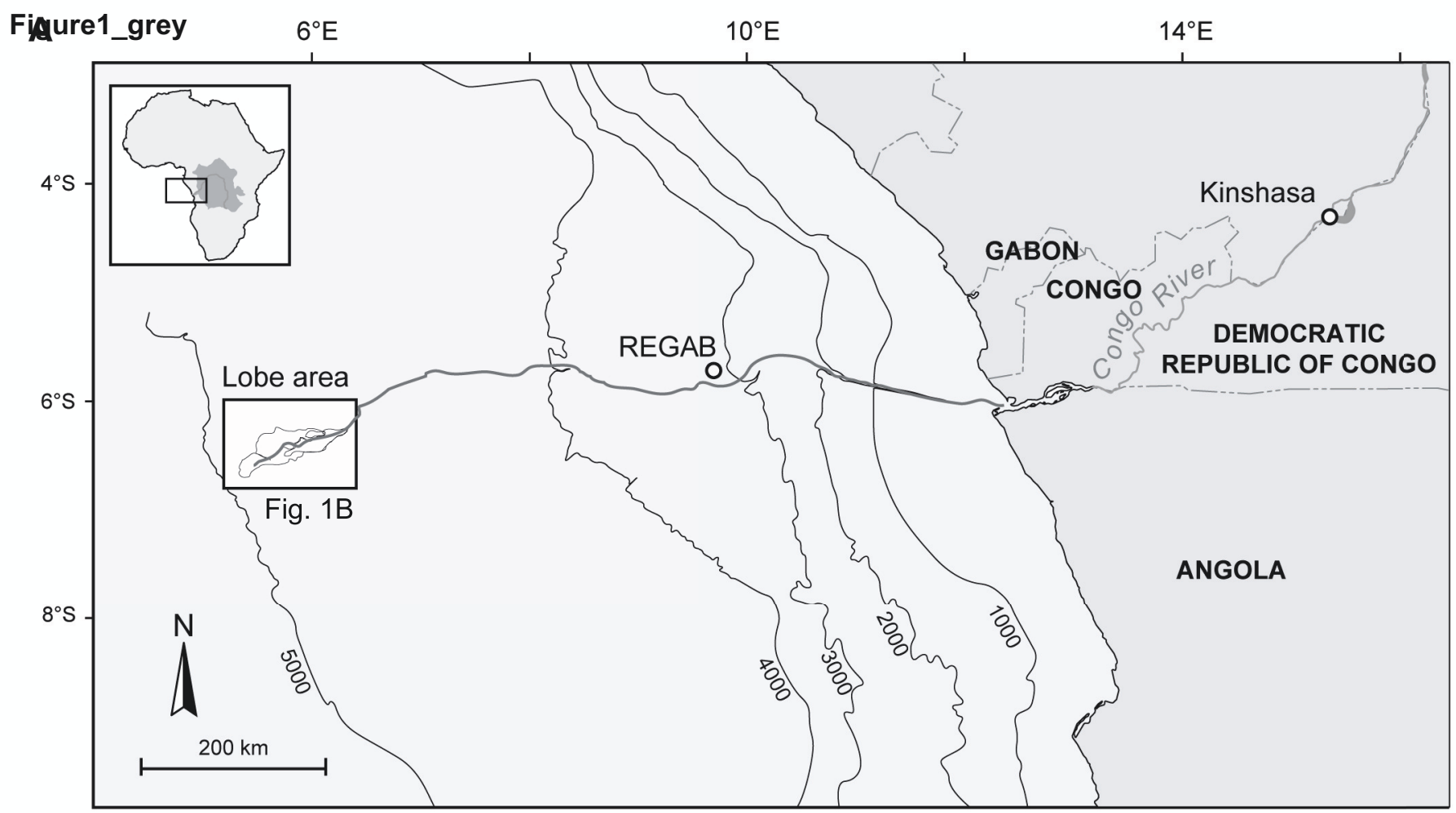

B

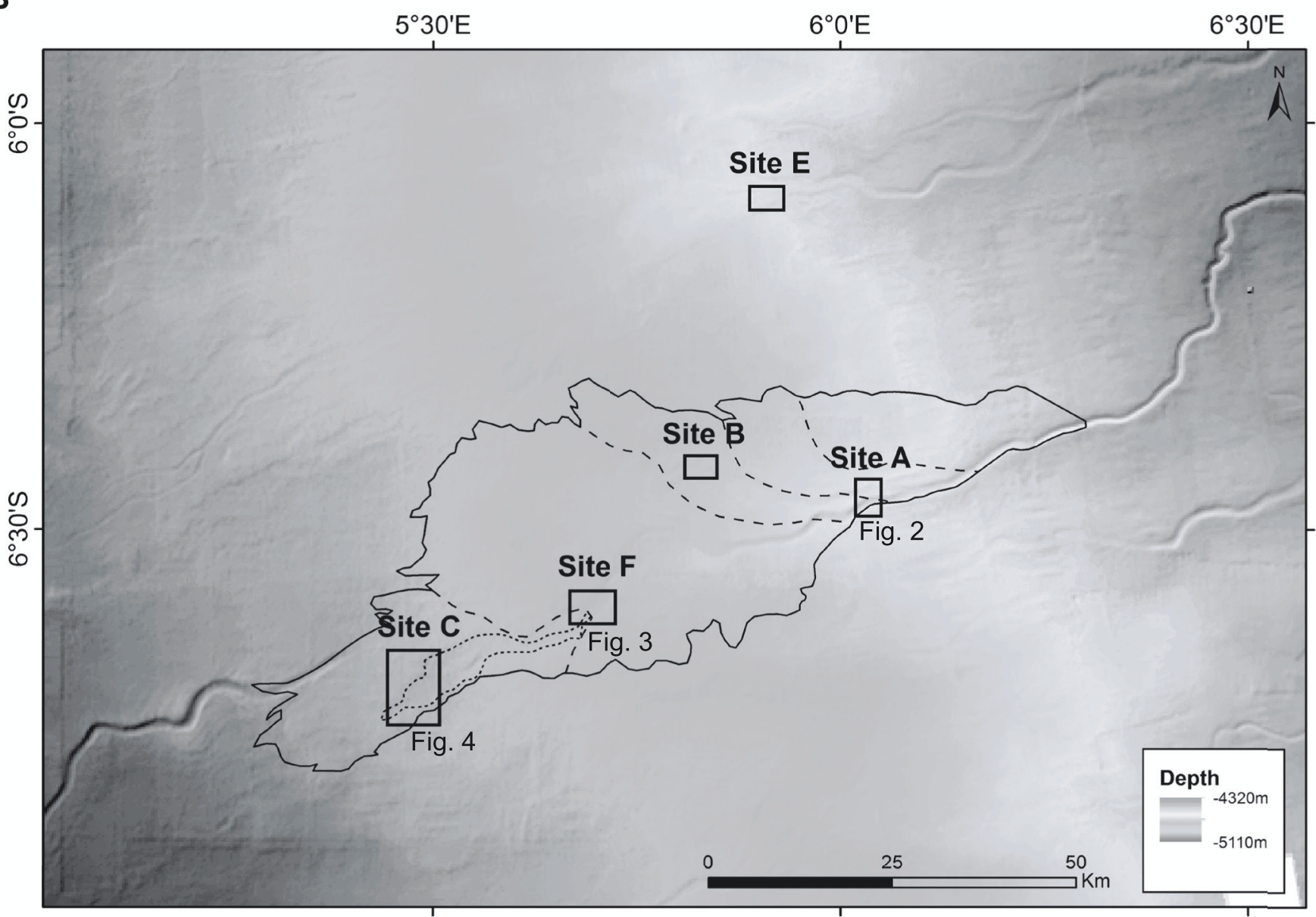




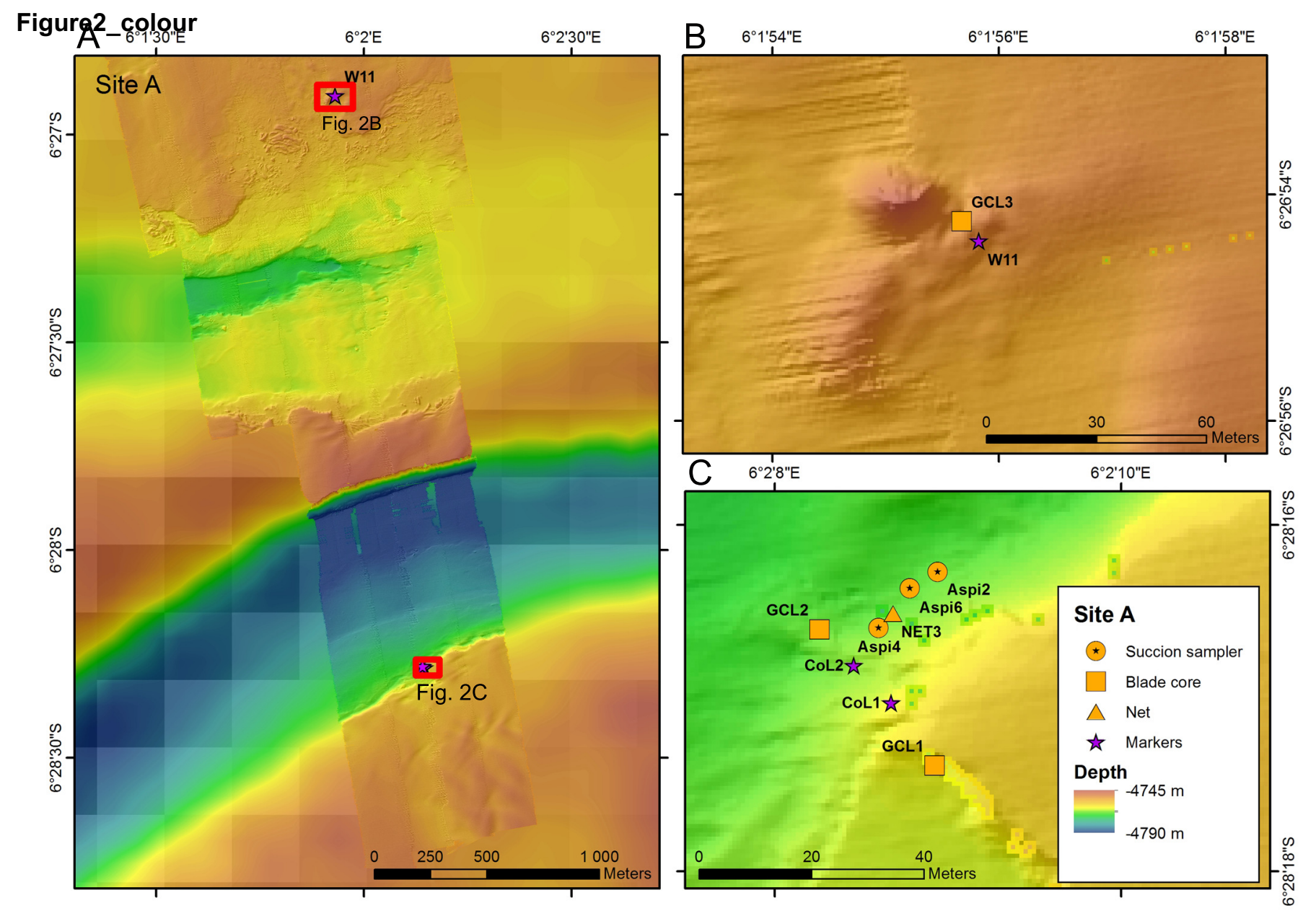




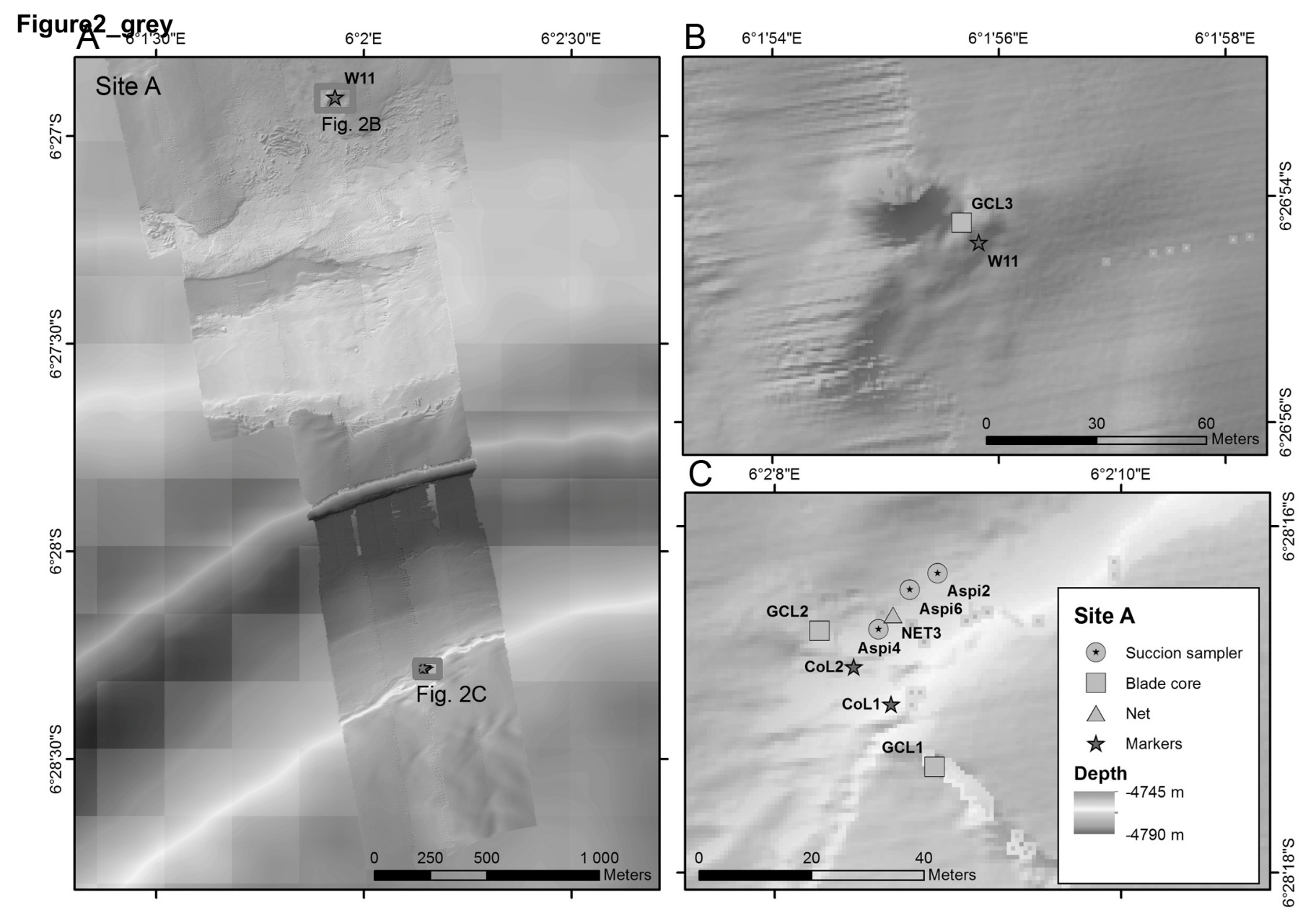




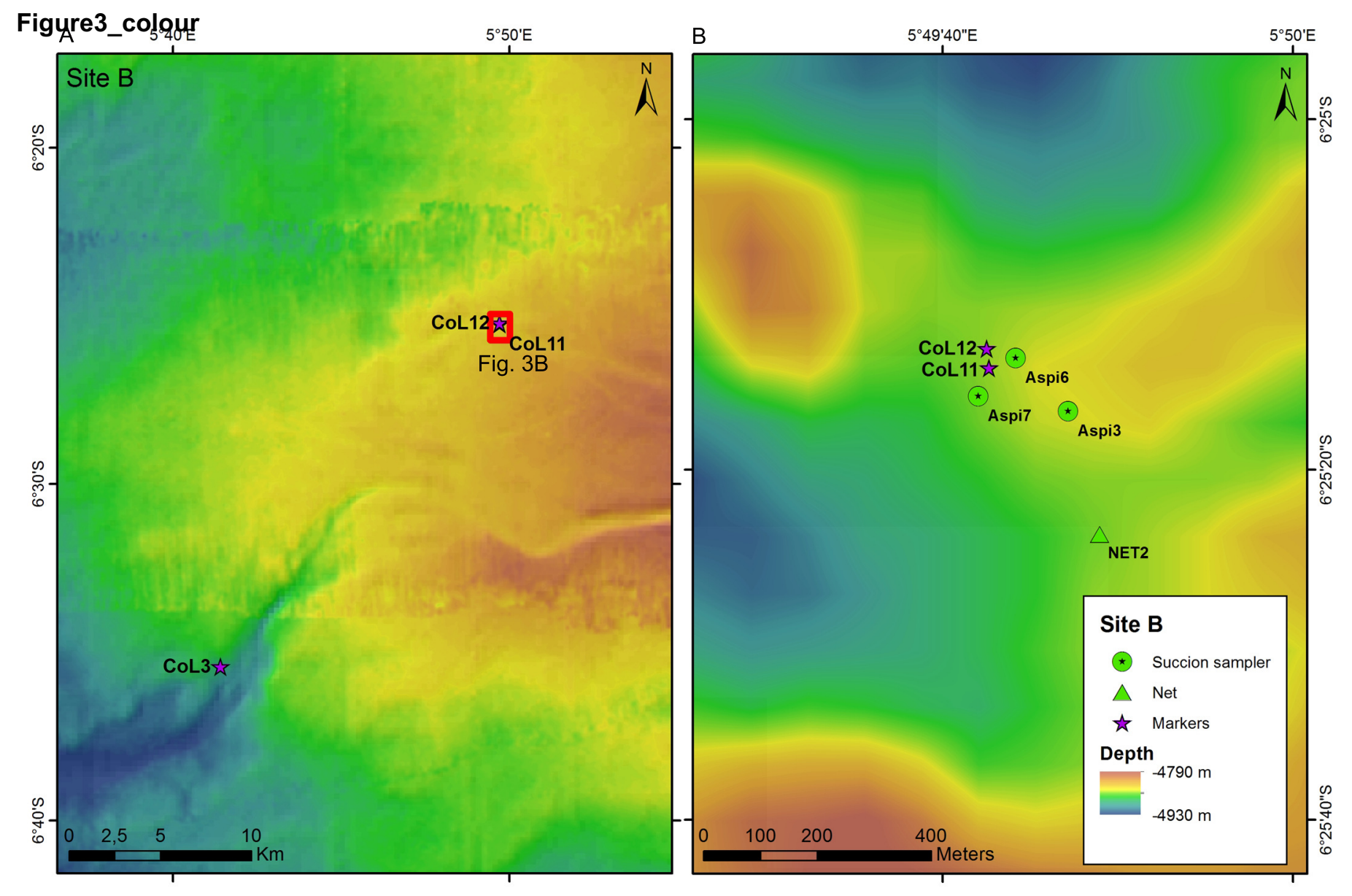




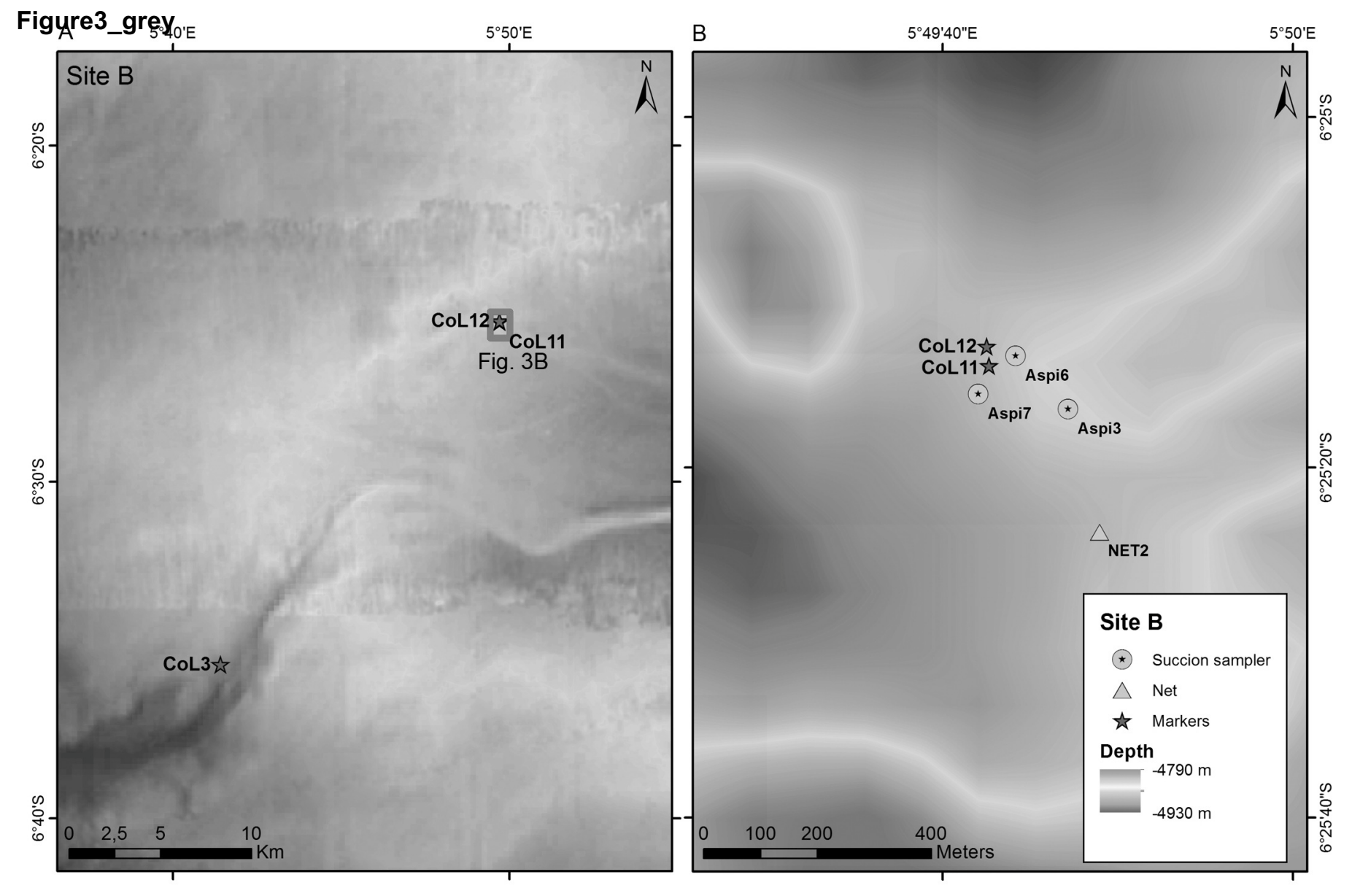



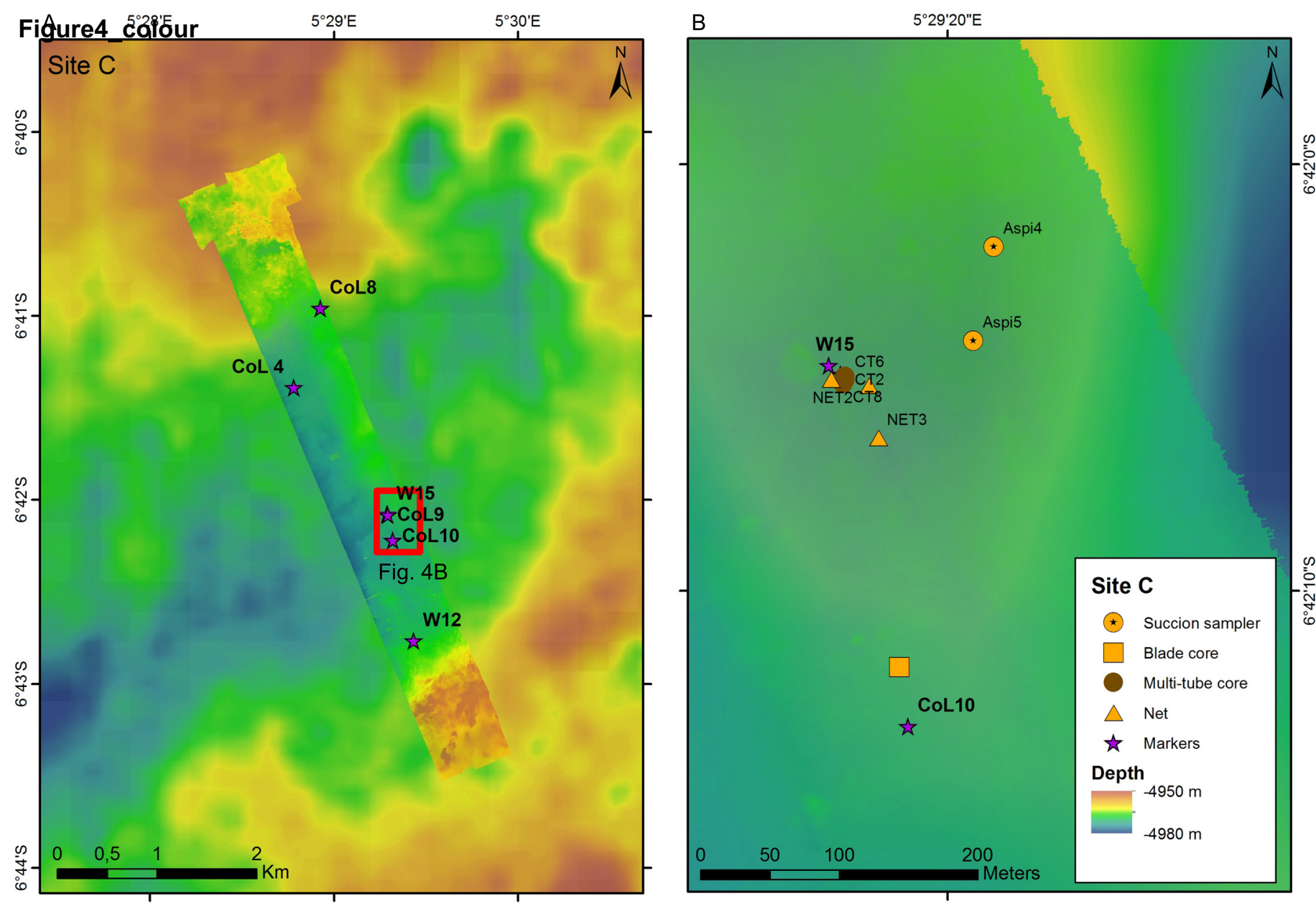

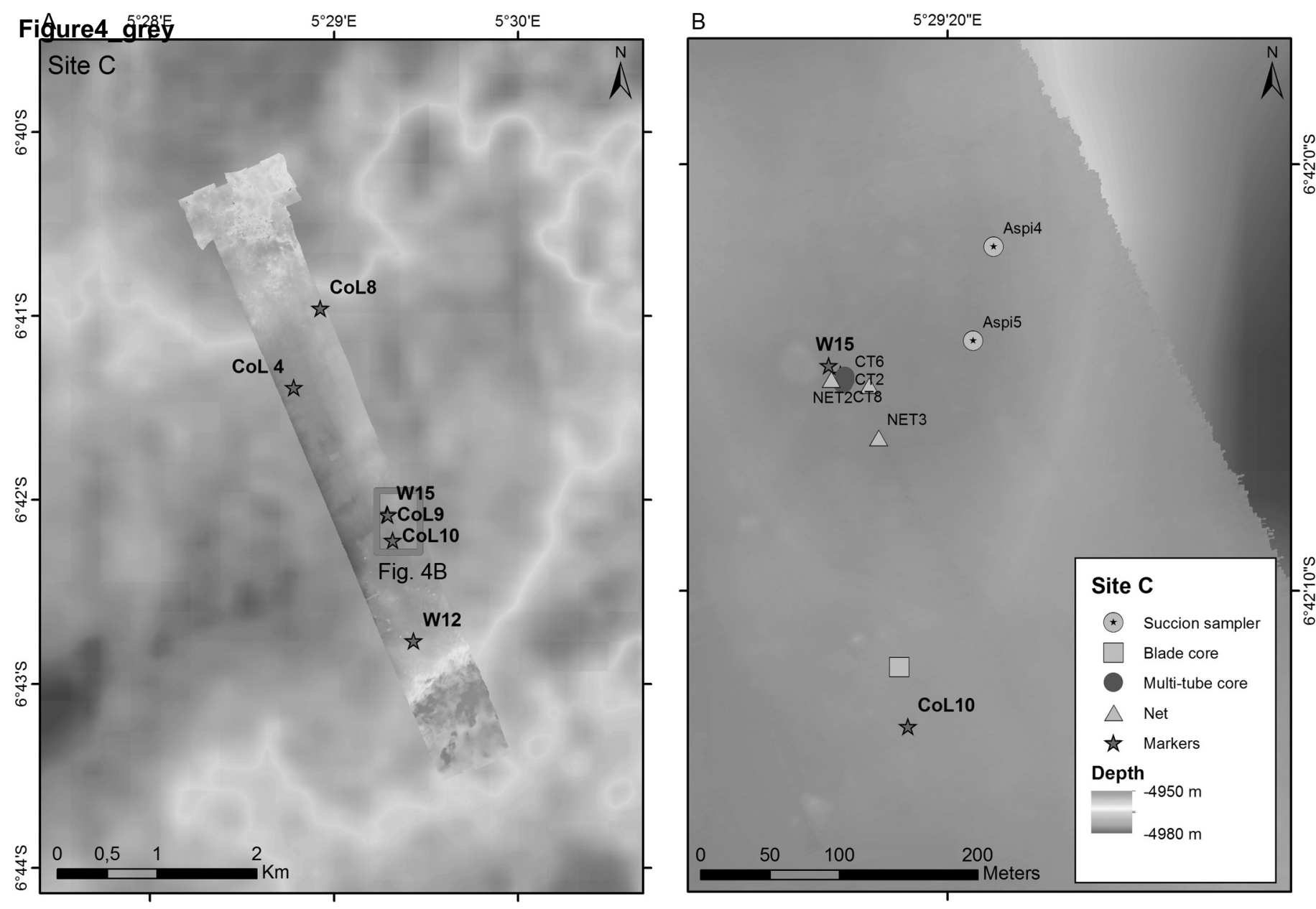

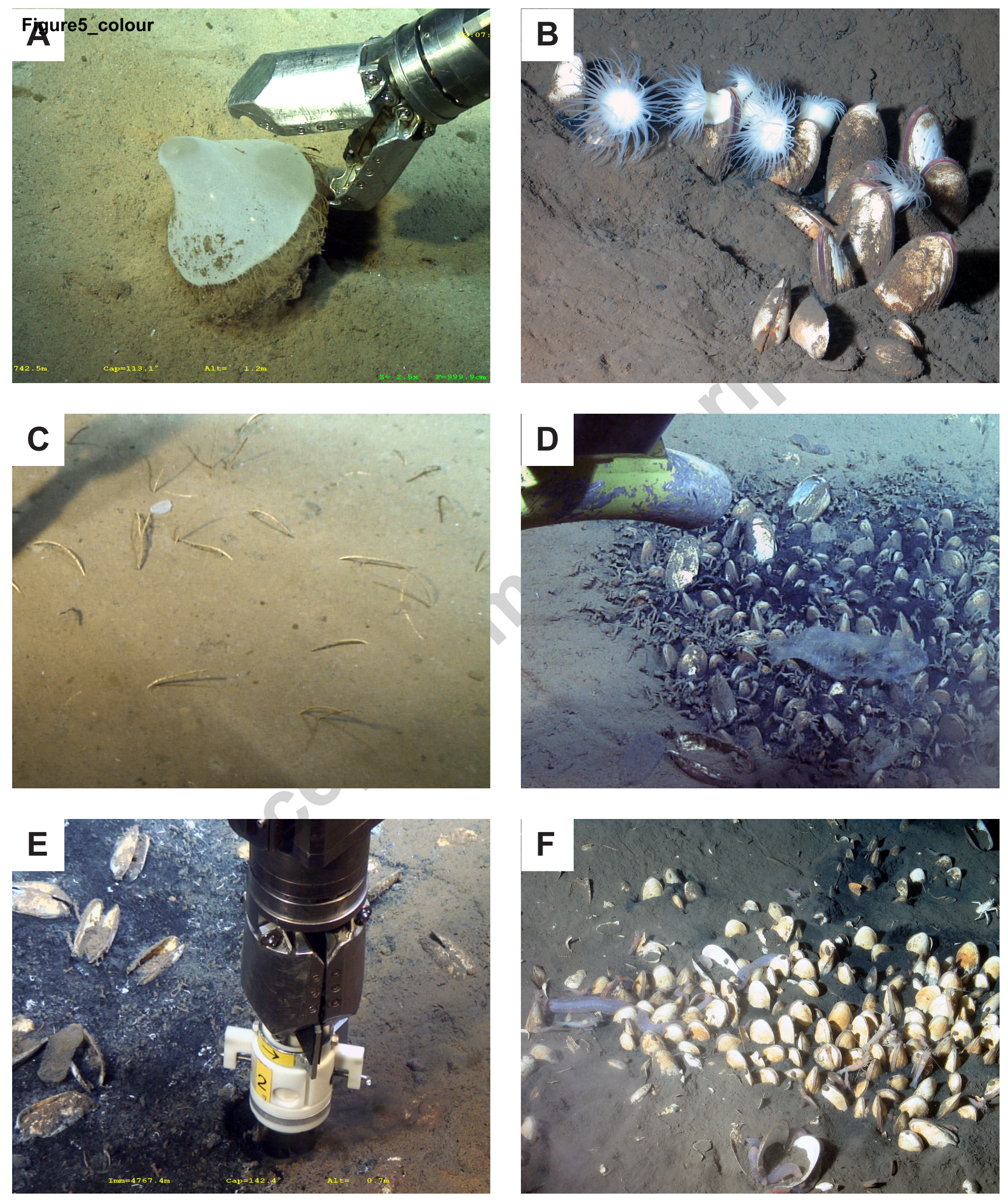

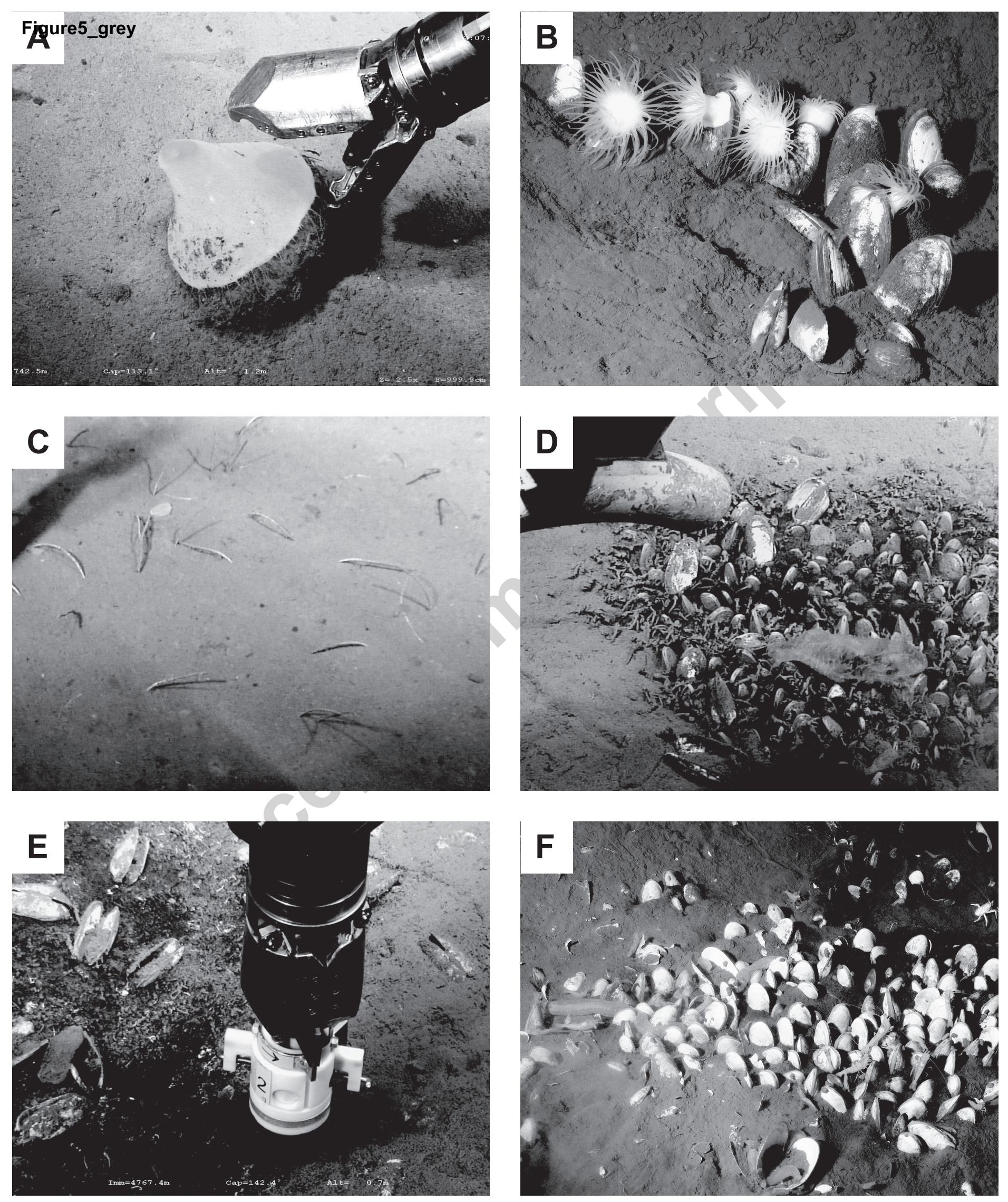


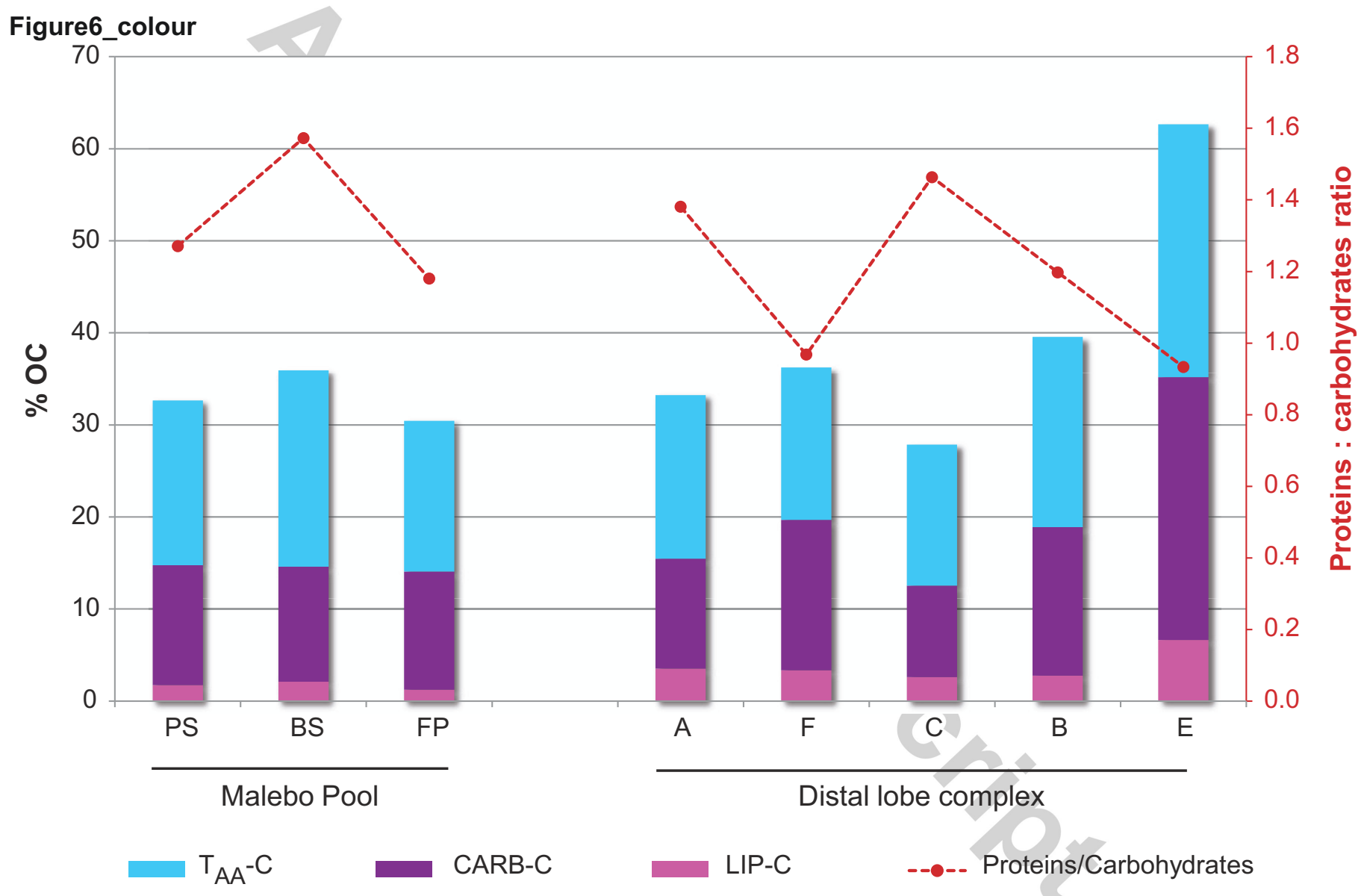




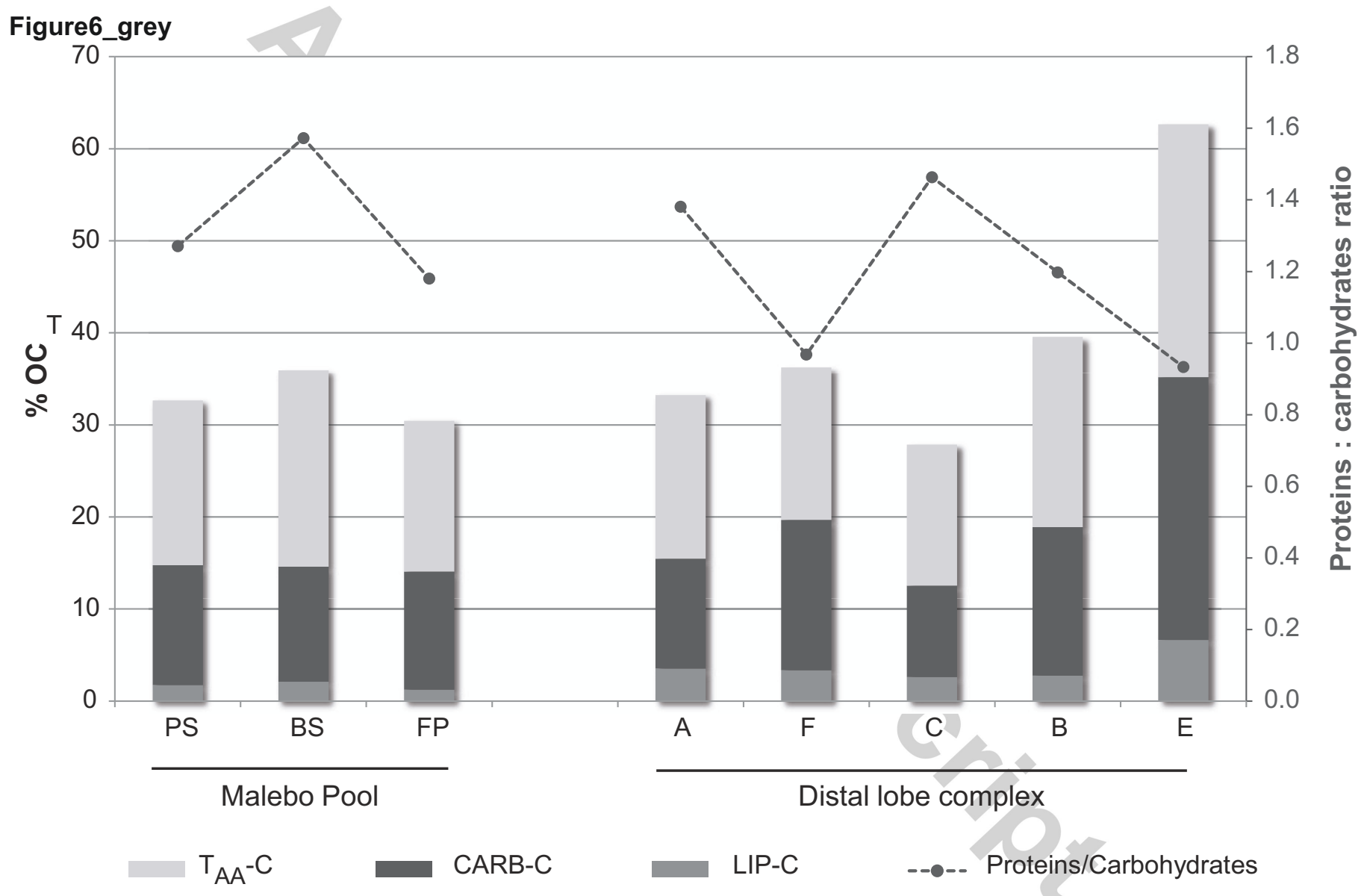


Figure7_colour

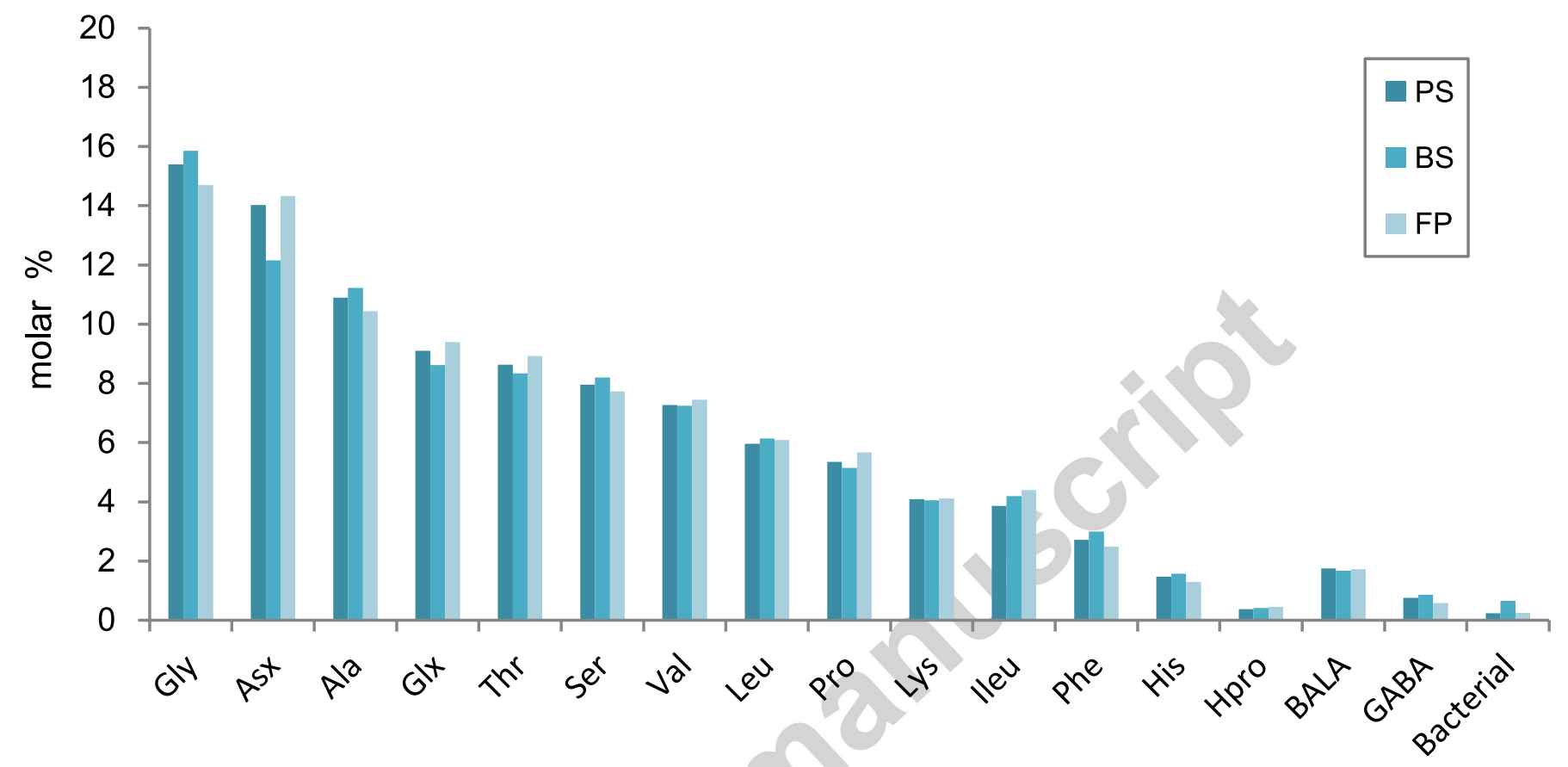

B

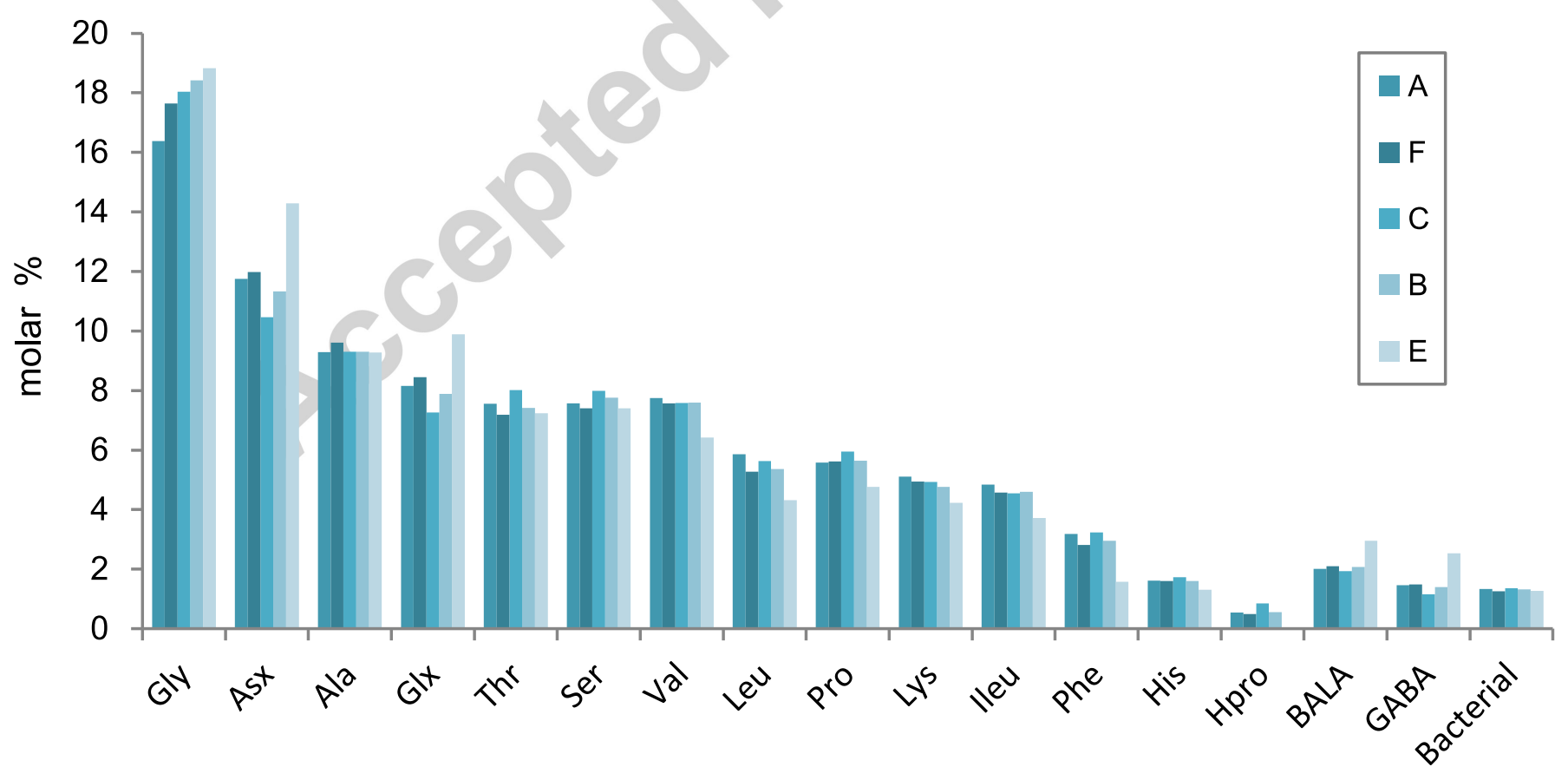


Figure7_grey

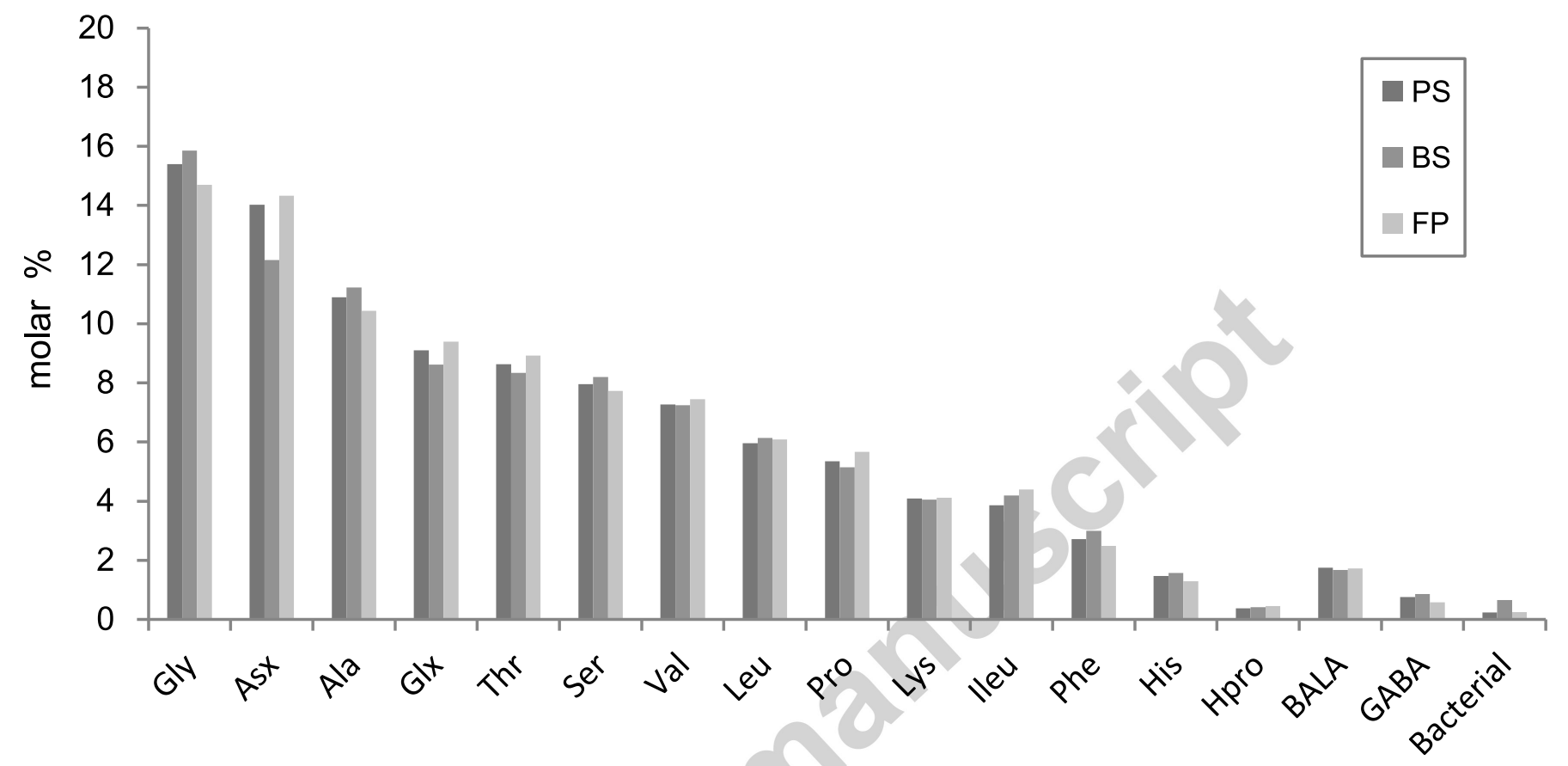

B

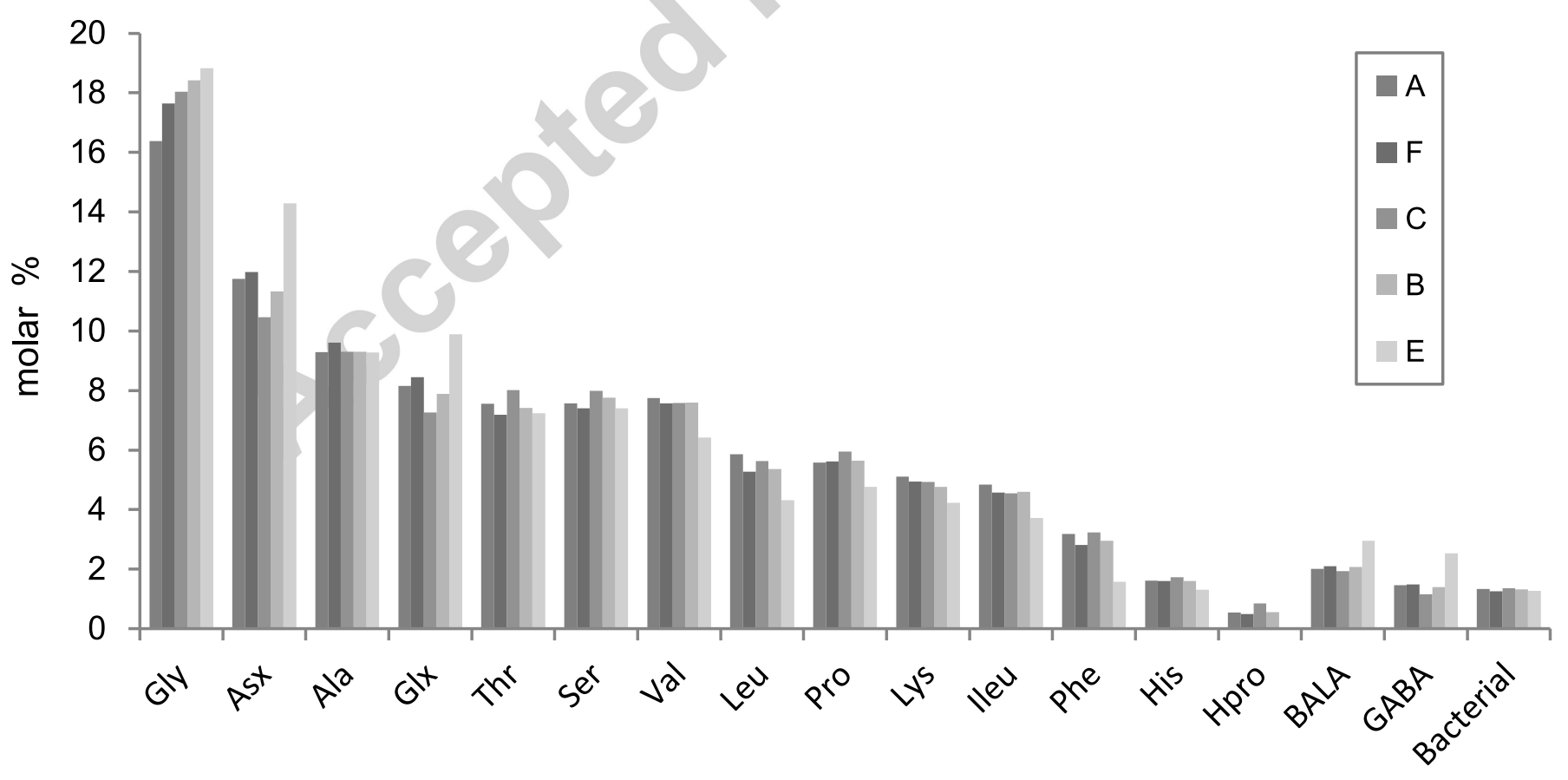


Figure8_colour

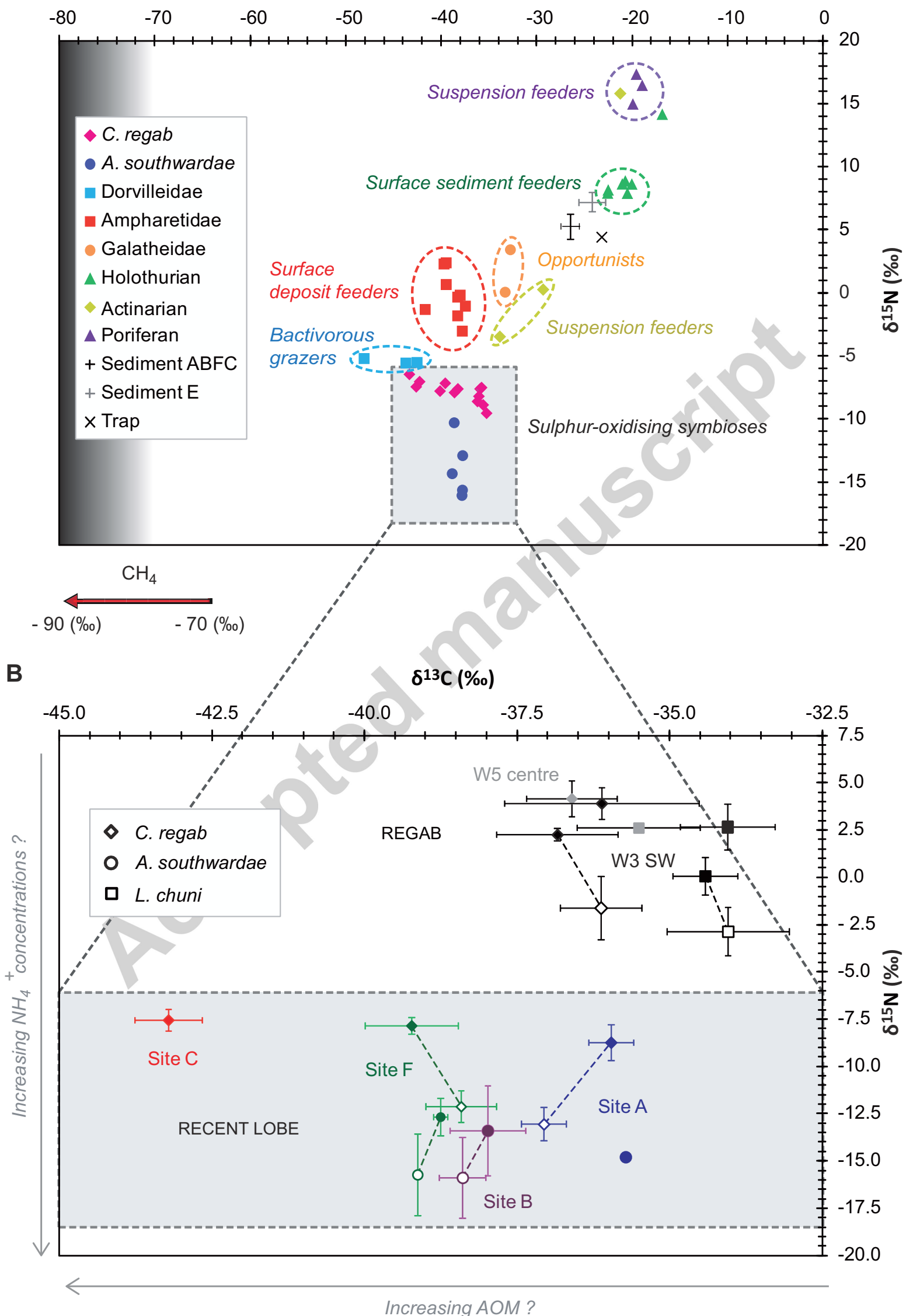

Increasing $A O M$ ? 
Figure8_grey

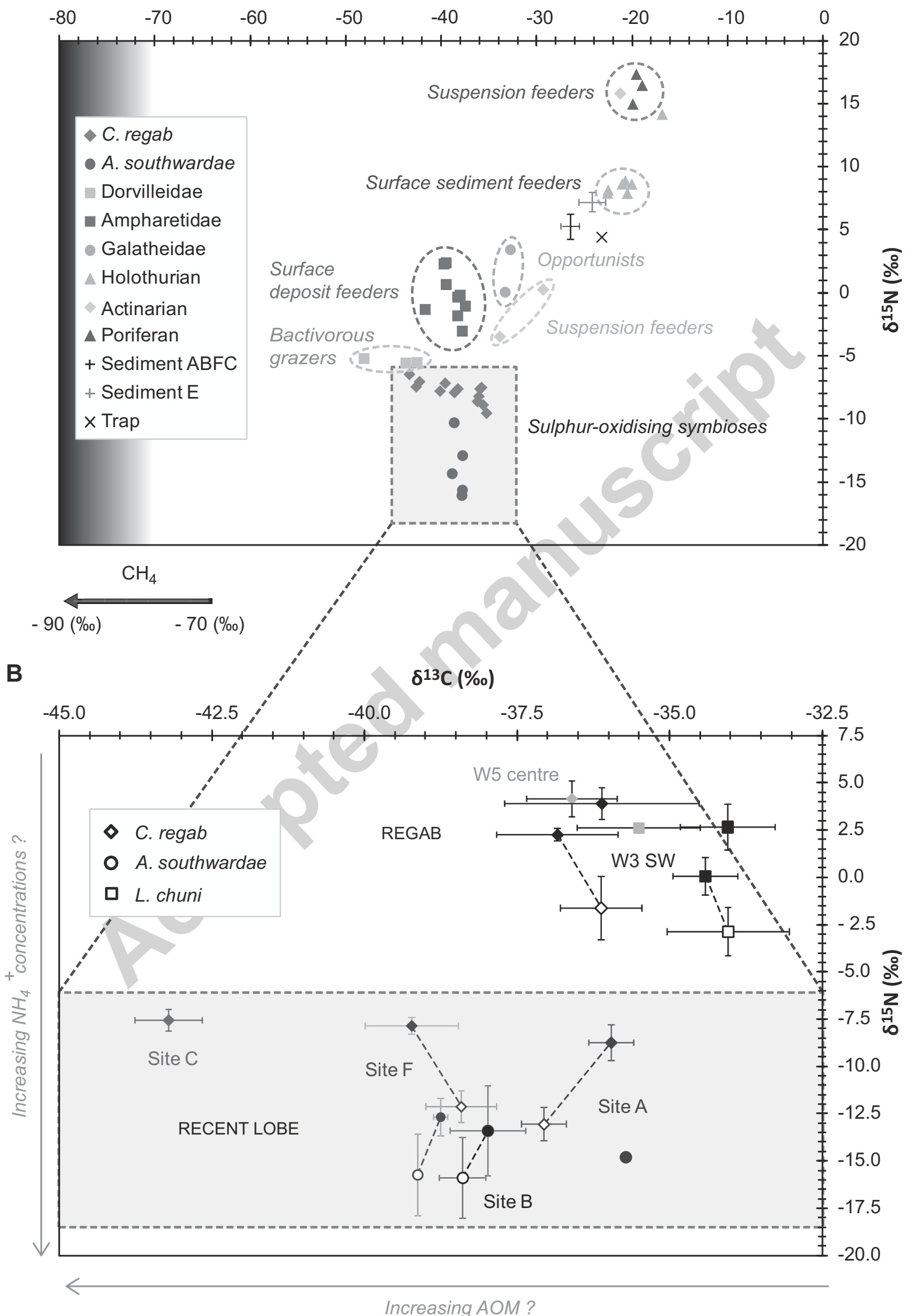

Increasing $A O M$ ? 


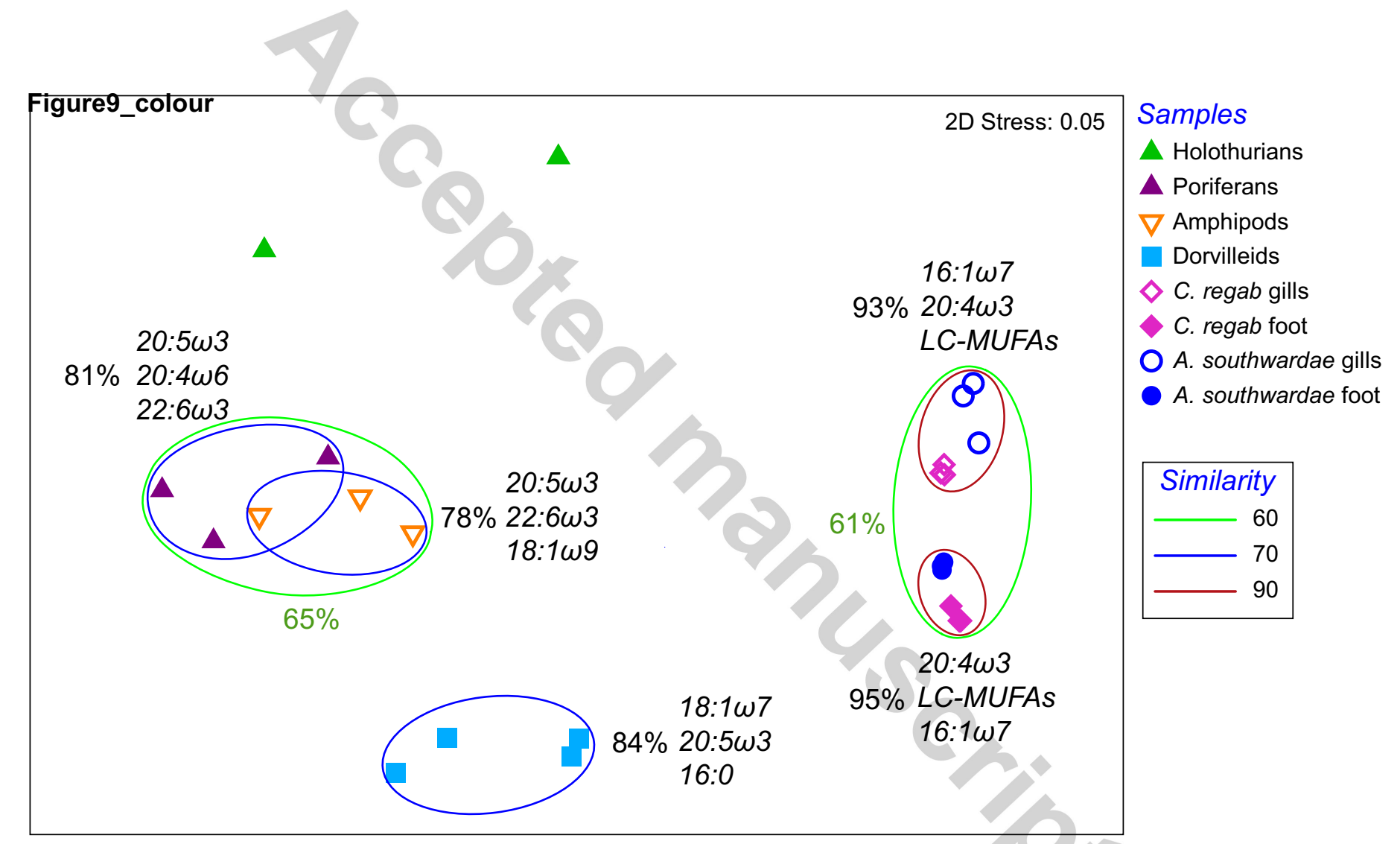




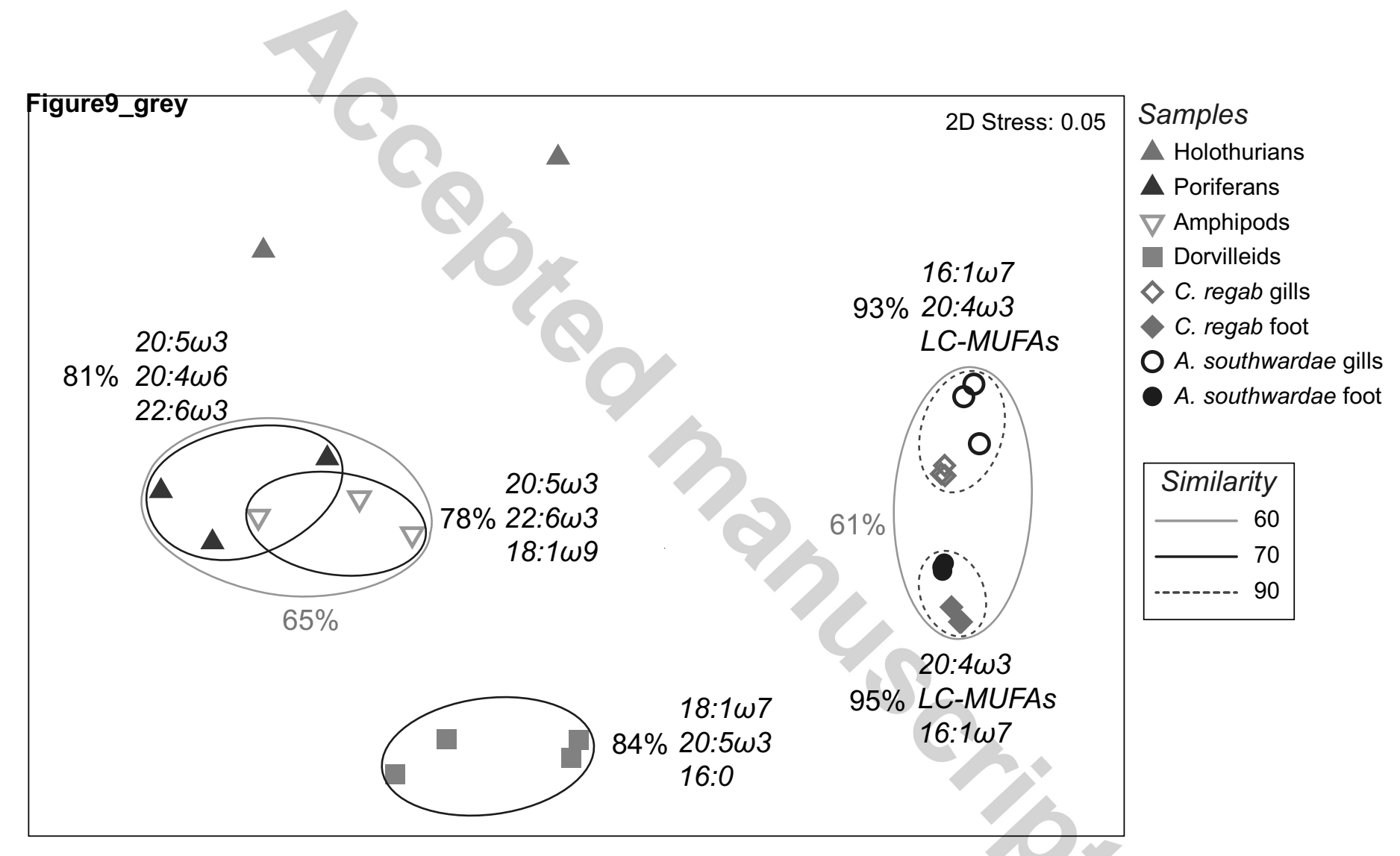


Figure $22_{5}$ colour
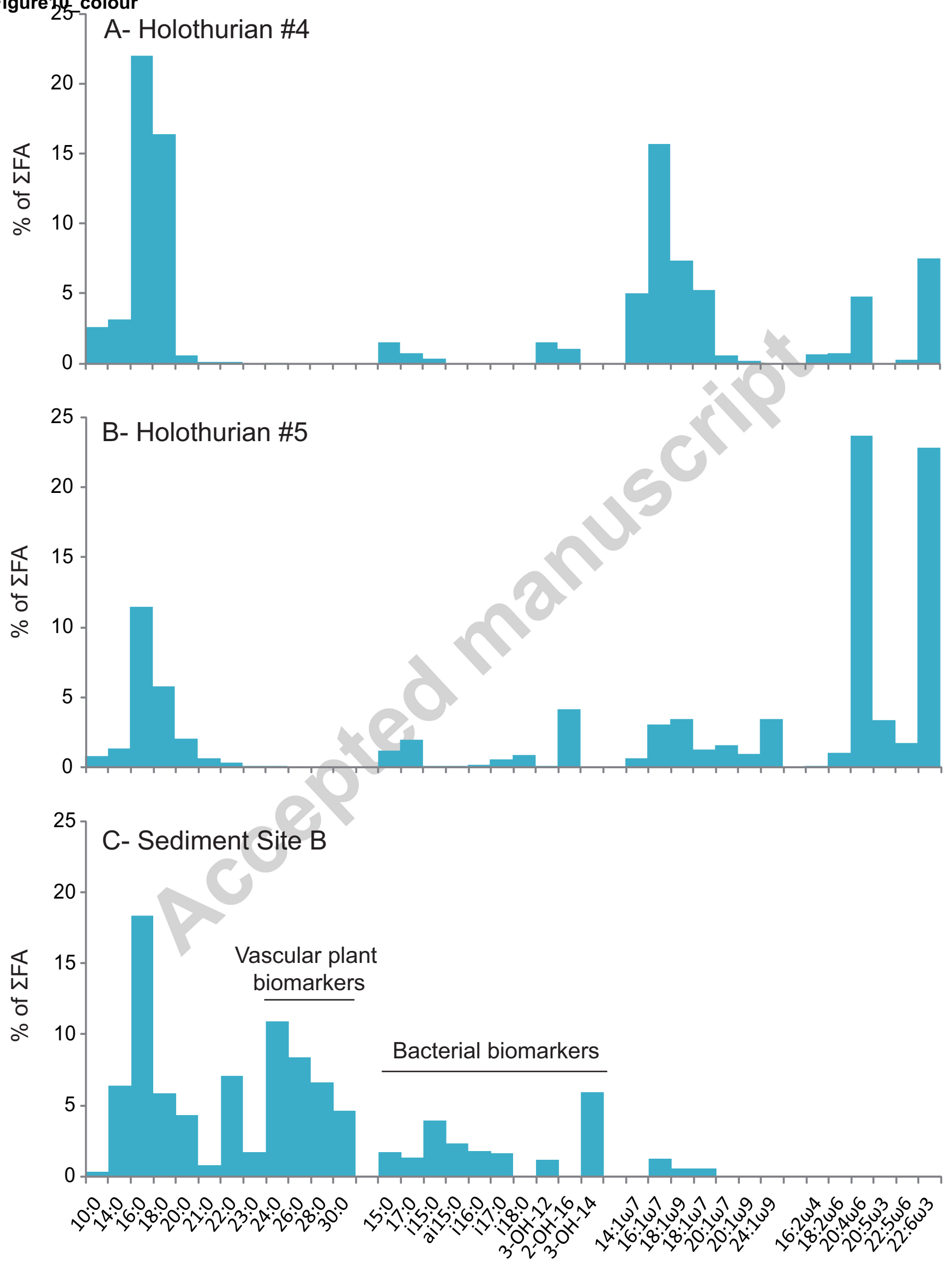
Figure10 grey
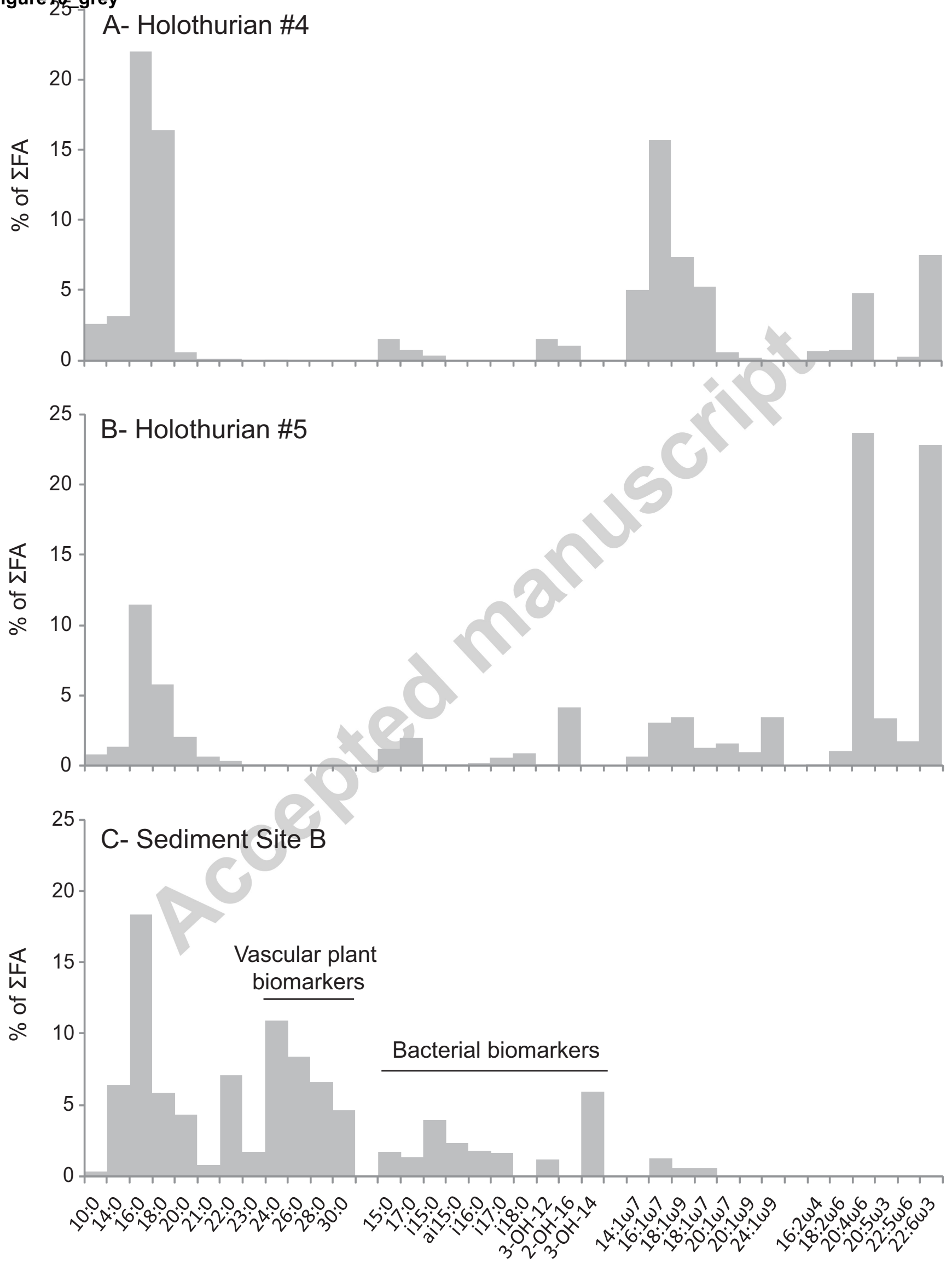